\title{
ESTUDO METODOLÓGICO DE AVALIAÇÃO DO CRESCIMENTO ÓSSEO AO REDOR DE IMPLANTES OSSEOINTEGRADOS ATRAVÉS DE MICROSCOPIA CONFOCAL DE VARREDURA A \\ LASER E TORQUE DE REMOÇÃO
}

EVANDRO DE TOLEDO LOURENÇO JÚNIOR

Tese apresentada à Faculdade de Odontologia de Bauru da Universidade de São Paulo, como parte dos requisitos para obtenção do Título de Doutor em Odontologia, na Área de Periodontia.

\section{BAURU-SP}

1998 


\section{ESTUDO METODOLÓGICO DE AVALIAÇÃO DO CRESCIMENTO ÓSSEO AO REDOR DE IMPLANTES OSSEOINTEGRADOS ATRAVÉS DE MICROSCOPIA CONFOCAL DE VARREDURA A LASER E TORQUE DE REMOÇÃO}

\section{EVANDRO DE TOLEDO LOURENÇO JÚNIOR}

Tese apresentada à Faculdade de Odontologia de Bauru da Universidade de São Paulo, como parte dos requisitos para obtenção do Título de Doutor em Odontologia, na Área de Periodontia.

Orientador: Prof. Dr. Aguinaldo Campos Júnior

\section{BAURU-SP}

1998 


\section{Lourenço Júnior, Evandro de Toledo}

Estudo metodológico de avaliação do crescimento ósseo ao Redor de implantes osseointegrados através de microscopia confocal de varredura a laser e torque de remoção. Evandro de Toledo Lourenço Júnior. --Bauru, 1998.

$00 \mathrm{p} ; 30 \mathrm{~cm}$.

Tese. (Doutorado) -- Faculdade de Odontologia de Bauru. USP.

Orientador: Prof. Dr. Aguinaldo Campos Júnior. 


\section{DADOS CURRICULARES}

\section{EVANDRO DE TOLEDO LOURENÇO JÚNIOR}

22 de maio de 1963

Juiz de Fora-MG

1982-1985

1987-1988

1989-1992

1994
Nascimento.

Curso de Graduação em Odontologia na Universidade Federal de Juiz de Fora-MG.

Curso de Especialização em Periodontia pela Sociedade de Proteção ao Fissurado LábioPalatal - PROFIS - Bauru-SP.

Curso de Pós-Graduação em Periodontia (Mestrado) na Faculdade de Odontologia de Bauru da Universidade de São Paulo, BauruSP.

Professor Assistente de Periodontia da Faculdade de Odontologia da Universidade Federal de Juiz de Fora-MG. 
à minha esposa Aneliese, por sua colaboração, compreensão, paciência e incentivo nesta jornada. Sem o seu auxílio a concretização deste trabalho seria impossível,

aos nossos filhos Breno e Marco que, de maneira inocente, tiveram que dispor de vários momentos de lazer e alegria junto a mim, para que eu pudesse realizar este estudo,

\section{DEDICO ESTA TESE}

A vocês, meu eterno obrigado! 
Um agradecimento especial e carinhoso aos meus pais Evandro e Aparecida, às minhas irmãs Maria Inês (Zi) e Eliza Maria (Tita), aos meus cunhados Fernando e Serginho, e ao meu sobrinho Rodrigo, pelo apoio e compreensão na realização deste trabalho.

Agradeço com carinho aos meus sogros Curt e Mirna, pelo apoio e estímulo constante. 
Ao meu Orientador e amigo, Prof. Dr. Aguinaldo Campor Júnior, pelo apoio, incentivo, exemplo, dedicação e amizade, o meu sincero agradecimento.

Aos Professores Euloir, Deoclécio e Sebastião, pela amizade, pelos ensinamentos e pelo convívio, o meu abrigado. 
À Liane, pela inestimável ajuda na confecção desta tese, o meu obrigado;

\section{À Adriana Silveira e à Adriana Passanezzi um agradecimento especial pelo auxílio no preparo e avaliação histológica.}

Aos meus colegas de turma, Wellington, Ricardo, Amália, Marta, José Augusto e Liane, pela amizade e pelos bons momentos de convívio. 
Ao meu amigo Dirceu Alves Amorim, veterinário nato, pelo apoio no manejo com os animais. Muito obrigado!

Agradeço a todos os funcionários da Periodontia e do NAPIO, pela atenção e pelo carinho. 


\section{SUMÁRIO}

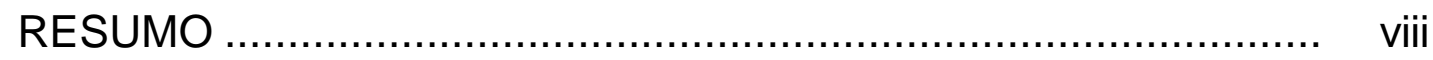

1 - INTRODUÇÃO …............................................................ 2

2 - REVISÃO DE LITERATURA …........................................ 6

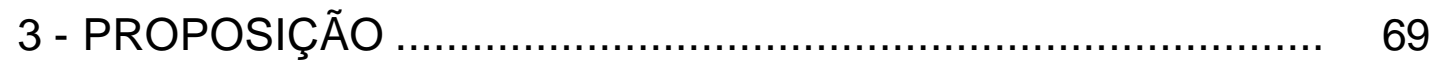

4 - MATERIAL E MÉTODOS ................................................... 71

5 - RESULTADOS …......................................................... 88

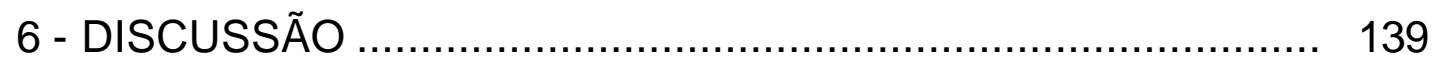

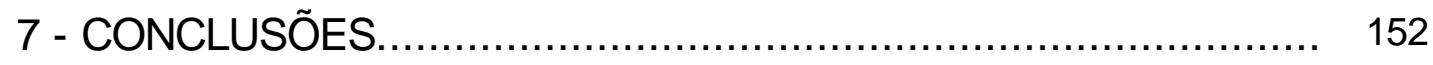

REFERÊNCIAS BIBLIOGRÁFICAS ......................................................... 154

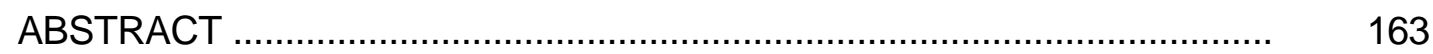


RESUMO 


\section{RESUMO}

A necessidade de uma compreensão cada vez abrangente sobre o fenômeno da osseointegração faz com que os pesquisadores busquem melhorias constantes nos meios de avaliação deste processo cicatricial. Para analisar as características deste fenômeno ao redor de implantes NAPIO inseridos em tíbias de coelhos, foi realizado um duploo acompanhamento pós-operatório (forças de torque e histológico). Sete animais foram usados neste experimento e cada um recebeu a colocação de 2 implantes, um para avaliação histológica e outro para obtençào da força de remoção por torque. Os animais receberam injeções intra-musculares de 3 diferentes marcadores da atividade óssea, tetraciclina, alizarina e calceína em diferentes intervalos de tempo:

Dia 0 - 14 implantes em 7 animais

Dia 7 - Tetraciclina em 6 animais

Dia 15 - Sacrifício animais 1 e 2 e Alizarina animais 3, 4, 5 e 6

Dia 21 - Alizarina animais 3, 45 e 6

Dia 45 - Sacrifício animais 3 e 4 e Calceína animais 5 e 6

Dia 52 - Calceína animais 5 e 6

Dia 90 - Sacrifício animais 5 e 6

Dia 180 - Sacrifício animal 7 (sem marcador)

No momento do sacrifício dos animais os implantes para torque foram removidos e os valores obtidos foram registrados:

Animal 1 - 7,49 N.cm (15 dias após a inserção) 
Animal 3-35,4 N.cm (45 dias após a inserção) Animal $4-31,1$ N.cm (45 dias após a inserção)

$\Rightarrow$ Média=35,25 N.cm

Animal $5-58,1$ N.cm (90 dias após a inserção) Animal 6 - 47,2 N.cm (90 dias após a inserção)

$\Rightarrow$ Média $=52,65$ N.cm

Animal 7 - 79,7 N.cm (180 dias após a inserção)

Os implantes para avaliação histológica foram processados pela técnica de Donath e analisados por microscopia confocal a laser, sendo detectada intensa atividade óssea na interface implante/osso.

Os resultados demonstraram uma contínua formação óssea circunjacente aos implantes e concomitantemente um aumento da força de remoção por torque à medida que o intervalo de tempo pósinserção aumentou. 
1 - INTRODUÇÃO 


\section{1 - INTRODUÇÃO}

Desde o início do século, vários pesquisadores, de maneira mais científica ou mais empírica, buscaram criar diferentes sistemas de implantes utilizando os mais diversos materiais. Vários sistemas que almejaram, em última análise, a reabilitação do paciente possuem nos dias atuais somente um valor histórico, aliado ao mérito do pioneirismo. Dentre os implantes que contribuíram para o conhecimento atual da implantologia podemos citar os implantes agulhados, subperiostais e laminados, os quais encontravam-se freqüentemente associados a infecções dos tecidos moles circunjacentes e a perdas ósseas aceleradas. Devido a inúmeras falhas na utilização dos sistemas de implantes e à falta de estudos clínicos bem controlados, o uso dos implantes manteve-se restrito a uma pequena parcela da comunidade odontológica. Entretanto, desde 1960, significantes pesquisas básicas e clínicas com um novo e, aparentemente, bem sucedido sistema de implantes, foram apresentadas e publicadas por Brånemark e seus colaboradores. Em 1977, Brånemark utilizou pela primeira vez o termo osseointegração, porém, o conceito sobre a existência de um contato direto entre o osso e os implantes metálicos, sem interposição de tecido mole, fôra descrito previamente em $1969^{15}$.

A partir da obsenvação da osseointegração até o início dos anos 80 ainda existia entre os profissionais da área odontológica uma certa 
desconfiança em relação à durabilidade e prognóstico para utilização dos implantes. Com a publicação de estudos longitudinais sobre a utilização dos implantes de titânio, o interesse pelos sistemas de implantes odontológicos osseointegrados tomou-se amplo, assim como a busca por novas técnicas cinúrgicas e pelos avanços obtidos na pesquisa dos materiais.

Entre as características que determinam o sucesso a longo prazo dos implantes estão, além da forma e material constituintes, aspectos inerentes à técnica cirúrgica propriamente dita. Procedimentos cuidadosos devem ser realizados, evitando-se o trauma sobre o tecido ósseo, por aquecimento ou pela remoção excessiva de tecido ósseo durante o preparo dos sítios receptores. Para que o processo de osseointegração se desenvolva com sucesso, deve-se observar contato íntimo do implante com o tecido ósseo, promovendo perfeita adaptação entre as estruturas. Além disso, idealmente, deve-se procurar "travar" o implante nas corticais superior e inferior (princípio do bicorticalismo), resultando em estabilidade primária dos implantes. Este cuidado impede a movimentação precoce dos implantes, o que poderia ocasionar alterações da dinâmica existente na interface titânio/tecido ósseo e, conseqüentemente, interferir no processo de osseointegração. Outro requisito importante a ser respeitado é a realização do procedimento cirúrgico em duas etapas, favorecendo o processo cicatricial sem a incidência de cargas funcionais diretamente transmitidas ao implante por período variável de 3 a 6 meses. 
Um sistema de implantes ideal deve permitir a transferência de forças ao tecido ósseo, sem que ocorra qualquer alteração no tecido circundante ou a nível sistêmico durante a vida do paciente. Esta permanência do implante em contato direto com o osso deve ocorrer, comprovando a biocompatibilidade do material. Entretanto, logo após a inserção de um implante no tecido ósseo, uma reação inflamatória ocorrerá e os eventos sucessórios a esta inflamação serão de fundamental importância para a longevidade do implante. Extrapolando para as condições bucais alguns conhecimentos de ortopedia pode-se perceber que é de fundamental importância a ausência total de movimento entre o implante e o leito receptor para que o titânio e o osso se unam, tornando viável a reabilitação. Vários trabalhos da literatura demonstram ocorrer, com o passar do tempo, uma maior condensação óssea ao redor dos implantes de titânio, o que significaria que a força de união na interface osso/implante aumenta quantitativamente em relação ao intervalo de tempo de maneira diretamente proporcional. O tecido ósseo passa também por um processo de maturação que pode ser observado utilizando-se técnicas de marcadores para o crescimento ósseo.

Baseado nesses conceitos, este trabalho foi desenvolvido com o objetivo de avaliar a força de união entre o osso e o implante (Sistema NAPIO) através de testes de remoção ao torque e determinar as áreas de atividade metabólica óssea através da injeção de marcadores de 
crescimento ósseo avaliadas por microscopia confocal a laser.

A utilização da técnica de microscopia confocal a laser devese a algumas vantagens oferecidas pela mesma em relação à microscopia óptica convencional. A primeira delas consiste na pequena profundidade de campo $(0,5$ a $1,5 \mu \mathrm{m})$ a partir da qual a microscopia confocal fornece informações cujos cortes ópticos apresentam-se mais bem definidos em relação à microscopia de luz convencional. As imagens fluorescentes desfocadas são eliminadas resultando em maior contraste, claridade e detecção da imagem. Uma segunda vantagem apresentada é o seccionamento óptico dos espécimes, uma vez que os artefatos oriundos do seccionamento físico observados na microscopia de luz e eletrônica são eliminados. Outra significativa vantagem da microscopia confocal é o seccionamento óptico que pode ser realizado em três planos ( $x, y$ e $z)$, o que permite observar uma célula em profundidade ou em lateralidade, além de se poder reconstruir a imagem em três dimensões ${ }^{55}$.

Além disto, a microscopia confocal à laser permite a observação de índices de transmissão e reflexão do raio laser incidente, oferecendo índices quantitativos objetivos quanto aos fenômenos de incorporação de marcadores aos tecidos, o que não é possível de maneira acurada com métodos colorimétricos. Este é justamente 0 objetivo deste trabalho metodológico, ou seja, a correlação entre índices obtidos pela microscopia confocal à laser e os método convencional, largamente exploraro na literatura, que é a medida de torque mecânico. 


\section{2 - REVISÃO DE LITERATURA}




\section{2 - REVISÃO DE LITERATURA}

No ano de 1981, ALBREKTSSON et al. $^{8}$ realizaram um estudo no qual procuraram analisar ultraestruturalmente implantes osseointegrados em função, em seres humanos. Um total de 3 grupos foi avaliado a partir de implantes removidos de 3 tipos de osso. No grupo I, 10 implantes de $\mathrm{Ti}$ em forma de parafuso foram removidos da mandíbula de 3 pacientes. No grupo II, 22 implantes foram removidos da metáfise tibial superior de 11 pacientes (6 meses após a inserção) e outros 2 implantes foram removidos do osso ilíaco. No grupo III, implantes foram removidos do osso temporal. A interface de união do osso/implante foi analisada por radiografias, por microscopia eletrônica de varredura, por microscopia eletrônica de transmissão e análise histológica convencional. Através de microscopia eletrônica de transmissão os autores sugeriram a ocorrência de uma ligação química entre osso e titânio devido à integridade da interface osso/implante.

Um artigo foi também publicado em 1981, no qual ADELL et al. $^{1}$ relataram o acompanhamento por 15 anos do total de 2.768 implantes inseridos em 191 maxilas e 219 mandíbulas de 371 pacientes. Dos 410 arcos operados, 405 receberam próteses e os pacientes apresentavam entre 20 e 77 anos de idade. As maiores taxas de perda óssea pós-inserção ocorreram desde a inserção do implante até o final do primeiro ano de utilização da prótese, representando em média 1,2 
mm. Após o primeiro ano em função, a média de perda óssea foi de 0,1 mm ao ano, salientando a importância da execução de uma técnica cirúrgica delicada e a necessidade de um período de cicatrização sem carga de 3 a 4 meses na mandíbula e 5 a 6 meses na maxila, para que ocorra a osseointegração. Os autores ressaltaram ainda a importância não somente da reabilitação bucal, mas também a recuperação psicosocial do paciente que sofria de edentulismo.

BRÅNEMARK $^{15}$ publicou um artigo em 1983, no qual demonstrou a base experimental para a descoberta da osseointegração. Neste conceituado artigo o autor demonstra que o fenômeno da osseointegração foi observado casualmente quando tentou-se remover as microcâmeras de titânio utilizadas para o estudo da biologia óssea por microscopia vital. Uma equipe interdisciplinar composta por cirurgiões plásticos, otorrinolaringologistas e outros profissionais passou a pesquisar a possibilidade de utilização dos implantes de titânio. Os estudos longitudinais experimentais demonstraram a possibilidade de ancoragem de próteses sobre implantes osseointegrados em cães. 0 primeiro paciente a receber uma prótese sobre implantes osseointegrados, de acordo com este fenômeno, teve seu tratamento realizado em 1965. Após análise e acompanhamento de vários casos, o uso desta técnica foi sugerido para tratamento de pacientes portadores de edentulismo, o que contrariava a literatura da época, que afirmava a impossibilidade de ancoragem em osso vivo de qualquer implante com 
carga por um longo período. Após 20 anos de avaliação experimental e clínica, o implante de titânio puro com dimensões de 3,7 mm de diâmetro e $10 \mathrm{~mm}$ de altura foi a alternativa de escolha para a grande maioria dos casos. Neste artigo o autor descreve a forma de fixação das próteses sobre os implantes, bem como outras aplicações extra-bucais dos mesmos.

Em 1983, ALBREKTSSON ${ }^{7}$ apresentou um artigo de revisão que englobava os aspectos biológicos necessários para obtenção de integração dos implantes de titânio no tecido ósseo. Para conseguirmos sucesso com um sistema de implantes o autor destacou: a) a biocompatibilidade do material utilizado, b) a condição do leito receptor, c) técnica cirúrgica atraumática e d) a época da carga sobre o implante. Em relação à biocompatibilidade, o autor demonstrou que o melhor material para utilização é o titânio e questionou a validade do uso de ligas de titânio para confecção de implantes, ressaltando ainda a formação de hemidesmossomas como um claro indício de compatibilidade com os tecidos moles. No que diz respeito ao leito receptor o autor recomendou que o mesmo não apresentasse sinais de infecção e possuísse altura adequada. Da mesma forma, o osso alveolar não deveria ser submetido a tomadas radiográficas após a colocação dos implantes. Quanto à técnica cirúrgica utilizada, o autor ressalta a importância de se evitar que a temperatura ultrapassasse $47^{\circ} \mathrm{C}$, porque este fato geraria uma menor área de necrose óssea, permitindo que 
ocorresse uma rápida e completa cicatrização. Em relação à aplicação de carga sobre os implantes o autor recomendou prazo de 3 a 6 meses após a colocação dos implantes para que o osso necrótico fosse totalmente substituído por osso vivo concluindo que uma meticulosa abordagem clínica poderia permitir uma osseointegração efetiva e duradoura.

Com o objetivo de avaliar o estado do conhecimento obtido até 1983 sobre a interface entre o implante e o tecido circundante, HANSSON; ALBREKTSSON; BRÅNEMARK ${ }^{39}$ avaliaram implantes de titânio comercialmente puro removidos por diversas razões, após preencherem os critérios de sucesso por períodos de tempo que variaram até 7 anos. Também foram realizadas avaliações em modelos animais com a finalidade de analisar situações que não seriam eticamente possíveis em seres humanos. Em relação a interface ossotitânio os autores, após avaliação de cortes histológicos, observaram que o titânio inserido em osso compacto de seres humanos induziu à formação e preenchimento ósseo ao redor do implante, significando que o implante estava ancorado por uma união ativa e camadas de osso remodeladas. $\mathrm{Na}$ avaliação da interface tecido conjuntivo-titânio, concluíram que o titânio foi aceito pelo tecido sem que ocorresse seu isolamento como corpo estranho. Em relação à interface formada entre o titânio e as células epiteliais os autores observaram a presença de hemidesmossomas unindo a margem das células epiteliais ao metal. Por 
estas razões, definiram o titânio como o metal de escolha para uso em implantes, pelo fato de, ao permanecerem estáveis e sem carga durante a fase de cicatrização, integrarem-se aos tecido dos humanos e dos animais.

Nesse mesmo ano, ERIKSSON; ALBREKTSSON ${ }^{34}$ procuraram avaliar as alterações teciduais ósseas após a variação de temperatura de $47^{\circ} \mathrm{C}$ a $50^{\circ} \mathrm{C}$, através de microscopia vital com câmeras instaladas na tíbia de 15 coelhos. Três diferentes grupos foram avaliados. No grupo $\mathrm{A}$, a temperatura foi elevada a $50^{\circ} \mathrm{C}$ por 1 minuto, no grupo $\mathrm{B}$ a $47^{\circ} \mathrm{C}$ por 5 minutos e no grupo $\mathrm{C}$ a $47^{\circ} \mathrm{C}$ por 1 minuto. Através da análise por microscopia vital durante o aquecimento, os autores observaram reações vasculares severas com alterações no fluxo sangüíneo demonstrando que o tecido ósseo é sensível ao aquecimento próximo a $47^{\circ} \mathrm{C}$. Destacaram nesse estudo a importância do controle do trauma cirúrgico para que não ocorressem danos ao osso em cicatrização, o que poderia ser irreversível se temperaturas elevadas fossem geradas durante a preparação do tecido ósseo por uma técnica intempestiva e inadequada.

Ainda no ano de 1983, LINDER et al. $^{58}$ utilizaram implantes cilíndricos de policarbonato recobertos por Ti cp (espessura de 120-150 nm) inseridos na tíbia de 5 coelhos para avaliar o comportamento celular circunjacente. Doze semanas após a inserção dos implantes, os coelhos foram sacrificados. Utilizando a microscopia 
óptica comum, os autores não conseguiram observar a interposição de tecido mole. Quando observada por microscopia eletrônica de transmissão a camada de $\mathrm{Ti}$ encontrava-se separada dos filamentos colágenos por um espaço de 20-50 nm. Dentro desse espaço foram observados proteoglicanas, ácido hialurônico e sulfato de condroitina bem próximos ao titânio. Afirmaram ainda que a espessura do leito de proteoglicanas tem o mesmo valor que a distância entre dois filamentos de colágeno na mesma fibra colágena e entre a membrana da célula e a fibrila colágena mais próxima. Após estas observações concluíram que existe uma grande biocompatibilidade entre 0 titânio e os tecidos biológicos.

Em 1984, BRÅNEMARK et al. $^{14}$ realizaram estudo experimental (cães) e clínico (humanos) no qual foram analisados implantes que penetraram a tábua óssea da fossa nasal e seio maxilar. Dois implantes foram inseridos bilateralmente na maxila de 3 cães de modo que penetrassem a cavidade nasal. Os animais foram sacrificados 1 ano após, e os tecidos duro e mole circunjacentes aos implantes foram analisados microscopicamente. Os exames radiográficos e histológicos não demonstraram sinais de reação tecidual adversa. Os implantes encontravam-se integrados ao osso sem formação de tecido fibroso na interface. Um total de 139 implantes, os quais trespassavam o osso do seio maxilar e da fossa nasal, foram inseridos na maxila de 101 pacientes. Quarenta e quatro implantes que penetraram o seio maxilar e 
47 implantes que penetraram a fossa nasal foram acompanhados por 5 a 10 anos, com índices de sucesso de 70 e $72 \%$ respectivamente. Vinte e cinco implantes que penetraram o seio maxilar e 23 que penetraram a fossa nasal foram observados por 2 a 5 anos, com índices de sucesso de 88 a $96 \%$ respectivamente. Os implantes que penetraram na fossa nasal e no seio maxilar não causaram efeitos indesejáveis durante a cicatrização e mantiveram sua ancoragem quando submetidos a carga e quando removidos permitiram que a cicatrização se processasse sem formação de fístula.

Em estudo realizado em 1984 por ROBERTS et al. $^{72}$ avaliou-se a cicatrização óssea ao redor de 28 implantes de titânio puro colocados em fêmur de 14 coelhos com o objetivo de (1) investigar a biocompatibilidade óssea a um implante de titânio relativamente simples e barato, (2) determinar um período de cicatrização adequado para a obtenção de uma interface óssea rígida que poderia resistir à carga contínua, (3) descrever a ocorrência do modelamento e remodelamento ósseo após a aplicação de carga e (4) determinar parâmetros histomorfométricos e temporais do ciclo de remodelamento do osso cortical de coelhos. Os implantes utilizados possuíam $8 \mathrm{~mm}$ de altura e 3,2 $\mathrm{mm}$ de diâmetro e sofreram ataque superficial com ácido hidroclorídrico por 5 minutos antes do procedimento de autoclavação. Durante o preparo do leito cirúrgico receptor foram utilizadas brocas refrigeradas internamente por solução fisiológica isotônica em todas as 
perfurações imprimindo 3.000 rotações por minuto. Foram aplicados marcadores (Tetraciclina, Oxitetraciclina e Demecloxiclina) para uma posterior avaliação por luz ultravioleta. A avaliação histológica permitiu concluir que: 1) uma alta capacidade osteogênica foi preservada após o ato cirúrgico, 2) 6 semanas constituem um período adequado de cicatrização, antes da aplicação de carga, para obter-se uma estabilidade rígida e evitar fraturas em coelhos, 3) os implantes com carga contínua permanecem estáveis no osso e 4) os implantes podem ser utilizados como ancoragem ortodôntica e ortopédica dentofacial.

Buscando observar uma possível diferença no grau de reabsorção óssea após a colocação de implantes utilizando-se um ou dois procedimentos cirúrgicos, LARHEIM et al. ${ }^{56}$ avaliaram em 1984 implantes colocados em cães. Os implantes que sofreram dois procedimentos cirúrgicos, aguardaram um período de cicatrização entre a $1^{\underline{a}}$ e a $2^{\underline{a}}$ cirurgia. Os implantes colocados em um único procedimento já apresentaram comunicação com a cavidade oral durante 0 ato cirúrgico. Com a finalidade de estimar radiograficamente o grau de perda óssea entre os dois diferentes procedimentos, os implantes foram instalados contralateralmente na mandíbula dos cães e radiografias intraorais periódicas idênticas revelaram reabsorção óssea cervical em todos os implantes. Após 1 ano utilizando próteses fixas sobre os implantes bilateralmente, a reabsorção óssea variou entre 3 e $5 \mathrm{~mm}$. Os autores concluíram que nenhuma diferença foi observada entre os dois métodos 
em relação à reabsorção óssea.

Em 1984, WIE et al. $^{84}$ avaliaram a validade dos métodos clínicos utilizados para estimativa das alterações das estruturas de suporte de implantes dentais endósseos que encontravam-se em função. Foram avaliados 12 implantes inseridos em 3 cães da raça labrador. 0 período de observação compreendia 3 meses submersos e 6 meses em função. Na presença de limpeza gengival diária, os índices de placa e de sangramento gengival foram reduzidos ao redor dos implantes. Nenhuma correlação foi observada entre os índices de sangramento gengival e o grau de reabsorção óssea. A correlação entre a sondagem e as medidas radiográficas foi estudada por meio da comparação de 136 medidas paralelas. A diferença média foi de $0,4 \mathrm{~mm}$. Esses dados permitiram concluir que uma combinação da sondagem com as medidas radiográficas parece ser a informação mais confiável sobre o nível do osso de suporte e foi recomendada como controle de rotina dos implantes.

Em 1985, KAVANAGH et al. ${ }^{49}$ desenvolveram um modelo de estudo utilizando ratos Sprague-Dawley para avaliação da cicatrização, após a inserção de implantes revestidos por titânio. Colocaram-se 21 implantes revestidos por titânio na região dos segundos molares superiores. Os animais foram sacrificados após diferentes intervalos de tempo a saber: Grupo 1 (9) - 2 semanas; Grupo 2 (3) - 3 semanas e o Grupo 3 (9) - 4 semanas. A avaliação histológica das 
amostras revelou a presença de hemidesmossomas entre as células epiteliais e o titânio nos implantes avaliados 3 ou 4 semanas após a inserção. O grupo avaliado após 2 semanas não apresentava ainda a presença de hemidesmossomas. Os autores ressaltaram a importância deste tipo de modelo animal para avaliações histológicas, uma vez que questões éticas impediriam este tipo de estudo em humanos.

As reações do tecido ósseo em contato com o titânio e o zircônio foram comparadas em estudo publicado por ALBRETSSON; HANSSON; IVARSSON ${ }^{9}$ em 1985. Para tanto, utilizaram 10 coelhos, que foram submetidos à inserção de um implante de titânio e um implante de zircônio nas metáfises tibiais. As peças para análise foram removidas 6 meses após a inserção dos implantes. Os autores puderam observar que a zona mais próxima ao titânio consistia de um leito de proteoglicanas com 200 a $400 \AA$ de espessura, seguida por uma segunda zona com filamentos colágenos organizados ao acaso e, por fim, uma zona com feixes colágenos localizados a aproximadamente $1000 \AA$ da interface. Próximo ao zircônio, o leito de proteoglicanas foi de 300 a $500 \AA$ de espessura e o leito de feixes colágenos foi um pouco mais espesso que próximo ao titânio. Os autores concluíram que o titânio e o zircônio são bem aceitos pelo organismo, devido à ausência de reações adversas no tecido e pelo grande contato direto apresentado com o osso.

Neste mesmo ano, buscando avaliar a deposição sistêmica de titânio em diferentes tecidos do corpo, KELLER; YOUNG; 
HANSEL $^{52}$ analisaram estes tecidos em 3 macacos Rhesus adultos após a colocação de implantes na mandíbula dos mesmos. Os implantes permaneceram em posição por 52 a 76 semanas, após as quais os tecidos do fígado, rins, pulmão, baço, músculos esqueléticos e cardíaco foram avaliados histologicamente. A espectofotometria por absorção atômica revelou a presença de mínimas concentrações de titânio nos pulmões dos animais implantados e não-implantados (controle). Os autores afirmaram que as condições dos metais, o tratamento superficial e a limpeza dos mesmos contribuem para as características farmacocinéticas e de corrosão de um sistema de implantes, e que estudos futuros seriam necessários para avaliação destes tópicos.

Ainda no ano de 1985, LINDER $^{59}$ publicou um estudo que avaliou a interface entre osso e implante. Foram utilizados implantes cilíndricos de $\mathrm{Ti} \mathrm{cp}$ implantados na tíbia de coelhos e permaneceram em cicatrização por 3 a 4 semanas. Após esse período os implantes foram removidos com o auxílio de uma trefina, mantendo o osso ao redor das fixações. As peças foram desmineralizadas em EDTA e processadas para análise em histologia ótica e microscopia eletrônica. Os autores puderam identificar uma superfície de metal quase plana e sem sinais de separação do osso, sendo que a superfície plástica do material de inclusão não apresentou trincas ou defeitos. A região observada por microscopia eletrônica de transmissão apresentou células com superfície de aparência intacta e, da mesma forma, elementos filamentosos não 
danificados.

Em estudo publicado em 1986, ADELL et al. $^{2}$ avaliaram por um período de 3 anos, um total de 16 pacientes que receberam 95 implantes osseointegrados (7 maxilas e 9 mandíbulas). Os tecidos mole e duro circunjacentes aos implantes foram acompanhados por métodos clínicos e radiográficos padronizados nos períodos de 6, 11, 21, 30 e 39 meses após o tratamento. No último exame (39 meses) amostras microbiológicas e biópsias gengivais foram também analisadas. $\mathrm{O}$ percentual médio de intermediários (abutments) sem placa (70-75\%) e sem gengivite (80-85\%) foi sempre constante durante todo o estudo. A profundidade de sondagem média foi de $1,9 \mathrm{~mm}$ no exame final. Em torno de $75 \%$ das sondagens foram menores que $3 \mathrm{~mm}$ e nenhuma ultrapassou $5 \mathrm{~mm}$. A gengiva inserida circundou $65 \%$ das superfícies vestibulares e linguais dos implantes. Somente $0,9 \mathrm{~mm}$ do osso marginal foi perdido em média durante o primeiro ano e não mais do que $0,05 \mathrm{~mm}$ anualmente nos 2 anos seguintes. $O$ osso periimplantar tornou-se gradualmente radiopaco, especialmente na região marginal das maxilas, indicando um sucessivo remodelamento relacionado à carga. A microbiota compreendia cocos e bastonetes não-móveis em $93 \%$ de 32 amostras. Tecido sadio estava presente em 35\% das 14 biópsias de tecido mole e em $29 \%$ somente uma ligeira inflamação ocorreu. Os autores concluíram que a reação tecidual marginal foi discreta e não ocorreu evolução para periimplantite. O prognóstico para os implantes 
osseointegrados, segundo os autores, parece excelente, especialmente em relação à microbiota, à pequenas alterações ósseas marginais e ao remodelamento do osso periimplantar.

DEPORTER et al. ${ }^{29}$ relataram em 1986 os resultados da avaliação histológica da resposta cicatricial inicial após a colocação de implantes de uma liga de titânio com superfície porosa na mandíbula de 6 cães da raça beagle. Dois implantes foram colocados em regiões edêntulas de cada lado da mandíbula de cada cão e cobertos por um retalho de espessura total. Um dos lados da mandíbula cicatrizou por 4 semanas, enquanto o outro lado cicatrizou por 8 semanas antes do sacrifício dos animais. Cortes histológicos foram obtidos e avaliados qualitativamente e por morfometria computadorizada. Todos os 24 implantes, com exceção de 1, foram bem tolerados e cicatrizaram com crescimento ósseo variável na geometria da superfície porosa. A medida histomorfométrica revelou que o crescimento ósseo atingiu um grau máximo em 4 semanas de pós-operatório. Baseados nos resultados, afirmaram não haver vantagem em usar um período de cicatrização inicial acima de 4 semanas e que a carga protética poderia ser colocada nesse período.

Em artigo publicado em 1986, ERICSSON et al. ${ }^{33}$ relataram o emprego de implantes de titânio osseointegrados e dentes naturais como suporte combinado para próteses fixas em 10 pacientes parcialmente desdentados. Os dentes remanescentes apresentavam-se 
em pequeno número e também distribuídos de forma desfavorável nas mandíbulas para servirem como pilares para próteses fixas. As avaliações feitas nos períodos de 6 a 30 meses pós-operatórios revelaram bons resultados clínicos. Entretanto, algumas reações teciduais foram observadas indicando a presença de certas diferenças clínicas no comportamento funcional dos dentes pilares em relação aos implantes pilares. Apesar de não ocorrerem falhas durante o pequeno período de observação afirmaram não ser possível recomendar este tipo de técnica para próteses fixas.

Nesse mesmo ano, ALBREKTSSON; HANSSON ${ }^{4}$ publicaram um estudo no qual foi avaliada a interface entre o osso e uma superfície de policarbonato recoberta por aço inoxidável ou titânio cp. Os pesquisadores utilizaram 10 coelhos que receberam 2 implantes cada um, sendo um implante recoberto por aço e o outro por Ti cp. Outros 5 animais receberam pinos com camada de titânio evaporado, enquanto que no lado contralateral foram inseridos pinos borrifados com titânio. Os animais foram sacrificados 3 meses após a inserção dos implantes. Os implantes revestidos por aço inoxidável apresentaram, no mínimo, uma a duas camadas de células no leito circunjacente, com grande quantidade de células inflamatórias. Os implantes revestidos por titânio não apresentaram tecido interposto entre o osso e o Ti, não ocorrendo diferenças entre o titânio evaporado e borrifado.

Ainda em 1986, CARLSSON et al. $^{21}$ avaliaram três 
diferentes tipos de implantes de $\mathrm{Ti} \mathrm{cp}$ (parafuso, cilindro e lâmina em formato de $\mathrm{T}$ ), em relação às alterações teciduais. $\mathrm{O}$ total de 60 implantes foram colocados em 6 cães adultos (tíbia proximal e metáfise femoral). Após um período de cicatrização variável de 3 a 14 meses, os implantes foram removidos em bloco. Observou-se que não houve interposição de tecido mole entre o osso e o titânio na cortical óssea, sendo que os parafusos estavam firmemente osseointegrados. Não foram visualizadas diferenças na quantidade de contato ósseo após 3 ou 14 meses. A integração óssea observada nas placas apresentou uma camada de fibras em $20 \%$ da sua superfície, sendo inferior quando comparada aos parafusos. Os implantes cilíndricos apresentaram áreas em contato direto com o osso e áreas com fibras. Os autores concluíram que o contato entre o osso e o implante pode ser direto ao redor de toda a circunferência de um implante de titânio.

No ano de 1987, KELLER; YOUNG; TRANCICK ${ }^{53}$ desenvolveram um método simplificado para avaliação do crescimento ósseo no interior de um implante cilíndrico, oco e perfurado com $4 \mathrm{~mm}$ de diâmetro e $7 \mathrm{~mm}$ de altura. As perfurações apresentavam diâmetro de 0,6 mm, 0,9 mm e 1,0 mm. Quinze implantes foram colocados no fêmur de 15 coelhos e os animais foram sacrificados após 2, 4 e 8 semanas (5 coelhos por grupo). Após a obtenção dos resultados e análise estatística, pode-se concluir que o crescimento ósseo não dependeu do tamanho da perfuração utilizada, porém houve um contínuo crescimento ósseo desde 
a implantação até a $8^{\underline{a}}$ semana. Os autores salientaram que o método apresentado permite uma avaliação efetiva do crescimento ósseo no interior dos implantes perfurados (ou porosos).

Em 1987, JOHANSSON; ALBREKTSSON ${ }^{45}$ publicaram um estudo no qual procuraram avaliar o torque necessário para remoção de implantes em animais em diferentes intervalos de tempo pós-inserção. Relacionou-se os valores obtidos para o torque com o grau de contato osso-implante por meio de análise morfológica. Um total de 25 coelhos adultos foi dividido em 5 grupos a serem sacrificados 3 semanas, 1, 3, 6 e 12 meses após a inserção dos implantes. Foram inseridos 50 implantes (2 por coelho) na tíbia dos animais. Em cada intervalo supracitado um grupo de animais tinha um dos implantes removidos utilizando-se um torquímetro e o outro implante removido por uma trefina, que retirava uma razoável quantidade de osso ao redor do implante para avaliação morfológica. Os torques necessários para remoção dos implantes 3 semanas, 1, 3, 6 e 12 meses após a inserção foram 10, 16,8, 68, 77,6 e $88 \mathrm{Ncm}$ respectivamente. $\mathrm{Na}$ avaliação morfológica, observou-se aumento gradual do osso em contato direto com a superfície do implante de acordo com o aumento do intervalo de tempo pós-inserção.

Em 1987, THOUSEN; ERICSON ${ }^{80}$ publicaram um estudo no qual avaliaram morfologicamente o osso, a cartilagem e o tecido sinovial adjacente a parafusos de titânio inseridos na articulação do joelho de coelhos. Esta avaliação foi realizada 2, 4 e 6 semanas após a 
inserção dos parafusos. Observou-se, duas semanas após o procedimento, reabsorção óssea assim como formação de novo osso sobre a superfície do titânio. O processo inflamatório constatado foi transitório e a quantidade de osso no interior das roscas do parafuso aumentou progressivamente com o passar do tempo. A cartilagem articular regenerou-se e cobriu os parafusos de titânio. Os resultados desse estudo levaram à conclusão de que o titânio fornece uma superfície inerte para a proliferação dos tecidos em diferenciação in vivo.

Em 1987, COX, ZARB $^{26}$ publicaram um estudo no qual foram avaliados 25 pacientes com idade variando entre 20 e 69 anos, que receberam em suas próteses sobre implantes. O período de cicatrização dos implantes Brånemark foi de pelo menos 6 meses antes da instalação das próteses de acordo com a quantidade de gengiva inserida, o índice gengival e o grau de mobilidade. Todas as avaliações foram repetidas anualmente. Após um período de avaliação de 3 anos, pode-se concluir que: I-os implantes osseointegrados podem ser usados com sucesso previsível, já que o índice de sucesso foi $87,5 \%$ para os implantes individualmente e de $96 \%$ para as próteses implantosuportadas, II-técnicas protéticas alternativas àquelas propostas por Brånemark são possíveis de execução e almejadas, III - parecem existir fortes evidências sobre a falta de confiabilidade dos métodos de avaliação dos tecidos moles convencionais em relação ao monitoramento da eficácia dos implantes. 
HENRY $^{42}$ publicou um interessante artigo em 1987, no qual comparou a microestrutura superficial de dois diferentes tipos de implantes comerciais (Biotes System e Bone-Vent System). Dez amostras de implantes de cada sistema foram avaliadas por microscopia eletrônica de varredura e por análise espectrofotômetro. Os implantes Biotes apresentaram, ao final das avaliações, uma alta reprodutibilidade de sua composição, de sua geometria e de seu acabamento superficial. Os implantes Bone-Vent apresentaram uma composição e um acabamento superficial inconsistentes e altamente variáveis. Os autores ressaltaram que muitos aspectos da biologia da interface osso/implante estão relacionados com o acabamento superficial e com a composição dos implantes metálicos. Entretanto também afirmam que muitas pesquisas precisariam ser feitas para esclarecimento dos efeitos destes fatores e suas interrelações com os fenômenos físicos e químicos que são responsáveis pela integração osso/titânio.

Em um artigo publicado em 1987, ARLIN ${ }^{11}$ ressaltou algumas características que deveriam ser comuns a todos os sistemas de implante que buscassem a osseointegração. As primeiras consideravam os pré-requisitos para obtenção da osseointegração: a) biocompatibilidade do material; b) desenho macro-estrutural do implante; c) osso saudável no leito receptor e d) técnica cirúrgica adequada. Dando seqüência ao seu artigo, ARLIN descreveu algumas características da técnica cirúrgica para obtenção da osseointegração 
que seriam: a) brocas afiadas, b) alargamento gradual do leito receptor, c) pouca pressão, d) irrigação abundante, e) pressão intermitente, f) baixa rotação, g) localização adequada do implante e h) desenho adequado do retalho. Ainda no mesmo artigo, descreveu algumas evidências da osseointegração: a) nenhuma evidência radiográfica de espaço peri-implante, b) o implante não pode ser removido, c) o implante não pode ser movido ortodonticamente, d) o implante estava imóvel, e) histologicamente, havia osso em contato direto com o implante. Como conclusão, o autor afirmou que a obtenção de uma osseointegração é melhor do que qualquer outra forma de cicatrização.

Em 1987 foi publicado um artigo no qual LÜTHY; STRUB; SCHÄRER ${ }^{61}$ avaliaram o revestimento plasmático de implantes de titânio que foram esfoliados após diferentes intervalos de utilização em seres humanos. Sete implantes ITI e 8 implantes IMZ foram analisados por metalografia e comparados com implantes do mesmo tipo, porém não utilizados. Dois terços dos implantes removidos apresentaram diminuição significante da espessura do revestimento em comparação com os implantes não utilizados. Não houve correlação entre o grau de redução da espessura do revestimento e o tempo de função intra-oral. Diante dessas evidências, afirmaram que a maior força de adesão do revestimento dos implantes ITI em relação aos implantes IMZ ocorreu, provavelmente, devido à maior microdureza dos primeiros.

Ainda no ano de 1987, MEFFERT; BLOCK; KENT ${ }^{63}$ 
publicaram um artigo no qual 3 diferentes tipos de implantes foram analisados: 1) cilindro de titânio comercialmente puro; 2) cilindro de titânio $c p$ jateado com areia (irregularidades de 25 a $30 \mu \mathrm{m}$ ) e 3) cilindro de titânio cp. revestido por hidroxiapatita (75 $\mu \mathrm{m}$ de espessura). Nenhum dos implantes possuía roscas. Cento e um implantes foram colocados em 10 cães mestiços e removidos 1,4 e 10 meses após a inserção. Destes, 96 cicatrizaram sem sinais de infecção ou inflamação e 5 não foram bem sucedidos por razões desconhecidas ou erro do operador. Os implantes cilíndricos lisos apresentaram fibras paralelas ao longo eixo e foram facilmente removidos do local cirúrgico com uma cureta. Os implantes com superfície jateada apresentaram um encapsulamento delgado, que diminuiu acentuadamente do primeiro ao décimo mês, tornando-se indistingüível aos 10 meses. Todos os implantes recobertos por hidroxiapatita estavam histologicamente biointegrados, apresentando uma camada de osso lamelar na maior parte das superfícies, levando a concluir que estudos controlados devem ser realizados para acompanhar não somente o sucesso ou a falha do implante, mas também para relatar todos os parâmetros clínicos, dos tecidos mole e duro, que poderiam afetar a longevidade de um sistema de implantes.

No estudo publicado por DOUNDOULAKIS ${ }^{32}$ em 1987, foi avaliada a efetividade 5 métodos de esterilização sobre a superfície de implantes de titânio. As amostras de titânio foram limpas por dispositivo ultra-sônico e lavadas por água tridestilada antes da avaliação da 
esterilização. Os 5 métodos de esterilização utilizados foram: 1) esterilizador endodôntico de esferas de vidro, 2) autoclave; 3) calor seco (estufa), 4) radiação ultravioleta e 5) descarga de calor por radiofreqüência. Após o procedimento de esterilização, as superfícies dos implantes foram avaliadas por microscopia eletrônica de varredura, análise do ângulo de contato e espectroscopia infravermelha por reflexão interna. Concluiu-se que: 1) a esterilização convencional poderia comprometer as propriedades superficiais por aderentes orgânicos ou materiais heterogêneos estranhos, que, por sua vez, poderia influenciar no sucesso de qualquer sistema de implantes, 2) a série de testes realizados forneceu evidências adicionais sobre os efeitos adversos da esterilização por autoclave nas superfícies experimentais, assim como informação inicial sobre os efeitos degradantes do esterilizador de esferas de vidro para uso similar, 3) a esterilização por calor seco, apesar de não remover restos orgânicos de superfície das amostras, não forneceu uma energia superficial maior para as mesmas e 4) a esterilização de materiais de baixa energia superficial por descarga de calor por radiofreqüência e tratamento por ultravioleta pode ser recomendado para obtenção de uma limpeza criteriosa e uma energia superficial alta que estaria relacionada com adesão celular e fixação do implante.

\section{Em 1988, TJELLSTRÖM; JACOBSSON;}

ALBREKTSSON $^{81}$ apresentaram os resultados de um estudo em que 
avaliaram a força para remoção por torque de 10 implantes craniofaciais osseointegrados inseridos na região mastóide de osso temporal de 10 indivíduos voluntários. Dois implantes foram colocados em cada paciente, sendo que um deles foi utilizado para fixação de um aparelho auditivo e o outro foi utilizado para esta avaliação. Para remoção de 9 implantes, 3 a 4 meses após sua instalação, foi utilizado torquímetro, resultando em força média de remoção de $42,7 \mathrm{Ncm}$, com uma variação de 26 a 60 Ncm. Um dos implantes foi utilizado para avaliação histológica quando puderam ser constatadas áreas ósseas com continuidade direta com a superfície do titânio, apesar de existir algum tecido conjuntivo sem inflamação devido ao pequeno período de tempo após a inserção dos implantes. Os autores salientaram a capacidade de união entre o titânio e o osso à medida que aumenta o período de tempo após a inserção.

Um importante estudo retrospectivo multiclínico foi publicado por ALBREKTSSON et al. ${ }^{3}$ em 1988, englobando 14 equipes cirúrgicas não pertencentes à Universidade de Gotemburgo, com pelo menos 3 anos de experiência na utilização de implantes osseointegrados Nobelpharma $^{(R)}$. O número total de implantes inseridos consecutivamente nas 14 clínicas foi de 8.139. A evolução de cada implante foi relatada e todas as falhas nos implantes, independente da época ocorrida, foram publicadas. Os critérios de sucesso incluíram ausência de mobilidade do implante, ausência de zonas radiolúcidas nas radiografias e uma perda óssea anual, após o primeiro ano, menor que 0,2 mm. Na mandíbula 334 
implantes foram acompanhados por 5 a 8 anos, com somente 3 falhas, e um índice de sucesso de 99,1\%. Na maxila 106 implantes foram acompanhados por 5 a 7 anos, com um índice de sucesso de $84,3 \%$. Em mandíbulas enxertadas e irradiadas, 56 implantes foram inseridos e nenhum foi perdido durante acompanhamento de até 5 anos. Em maxilas irradiadas foram inseridos 16 implantes com 3 falhas relatadas, e em maxilas enxertadas 71 implantes foram inseridos com 12 falhas. A proporção de implantes mandibulares e maxilares submersos foi de $0,8 \%$ e $0,3 \%$, de implantes de pacientes que abandonaram o estudo foi de $0,3 \%$ e $0,6 \%$ e de implantes de pacientes falecidos de $0,9 \%$ e $1,2 \%$ respectivamente. Esses dados permitiram concluir que os implantes osseointegrados, se inseridos de acordo com as normas básicas propostas, apresentariam um alto grau de sucesso, indo de encontro, e até mesmo superando, qualquer índice de sucesso de outros sistemas de implantes já publicados.

Com a finalidade de avaliar a influência das diferentes superfícies dos implantes em relação ao torque necessário para a remoção dos mesmos, CARLSSON et al. $^{22}$, em 1988, publicaram um estudo no qual compararam implantes de superfície lisa e rugosa, confeccionados com titânio comercialmente puro em 5 coelhos adultos. Em cada um foram inseridos 1 implante liso e 1 implante rugoso no fêmur, totalizando 20 implantes colocados. Os valores obtidos na remoção por torque foram maiores para os implantes rugosos em relação 
aos lisos, 6 semanas após a inserção. Os dois tipos de implantes apresentaram osseointegração, ou seja, estavam ancorados no osso sem interposição de qualquer camada de tecido mole, como foi demonstrado por histologia na interface óssea, segundo os autores.

Em um abrangente artigo publicado por KASEMO; LAUSMAA $^{48}$ em 1988, várias reações que ocorrem na interface implantetecido ósseo foram analisadas em relação às propriedades superficiais dos implantes. Dentre as propriedades superficiais que poderiam influenciar a cicatrização, os autores destacaram: a composição química, a contaminação e a limpeza, a microarquitetura e a estrutura dos implantes. A ciência das superfícies poderia oferecer uma gama de métodos para a caracterização superficial (espectroscopia por fotoemissão radiográfica, espectroscopia por elétron Auger) e preparação, que poderiam ser utilizados para otimização da fabricação dos implantes com controle a nível molecular. Os autores afirmaram que os métodos de preparo disponíveis poderiam ser usados em combinação com técnicas analíticas para moldar as superfícies dos implantes para diferentes aplicações clínicas. Ressaltaram ainda que o maior obstáculo a ser enfrentado seria a falta de conhecimento sobre como as diferentes propriedades superficiais influenciariam a resposta do hospedeiro, sendo este o maior desafio na evolução das pesquisas sobre biomateriais na área da implantodontia.

Buscando avaliar a interface osso-implante, ROBERTS ${ }^{71}$ 
publicou em 1988 um artigo de revisão sobre a metodologia histológica utilizada para avaliação da cicatrização óssea. Afirmou que a microrradiografia de alta resolução e a marcação fluorocrômica múltipla eram métodos histológicos definitivos para avaliação dos mecanismos e do intervalo para cicatrização, maturação e adaptação óssea. Dois tipos fundamentais de cicatrização de interface entre o tecido e os implantes dentais endósseos foram descritos: 1) fibro-ósseo integração e 2) fixação óssea rígida (osseointegração). A reação cicatricial inicial envolvia predominantemente a remodelação óssea nas superfícies do periósteo e do endósteo (ex.: preenchimento de calo ósseo por lamelas através do processo de compactação lamelar. A interface óssea não vital e a compacta adjacente foram substituídas pelo remodelamento ósseo (turnover). Através de análise por microrradiografia de alta resolução, amostras que obtiveram "sucesso clínico" apresentaram menos da metade da interface intraóssea em contato direto com o osso. Extrapolando dados obtidos em animais, sugeriu-se que os implantes podem sofrer carga com restaurações provisórias 18 semanas após a colocação dos mesmos, porém, a maturação da interface necessitaria aproximadamente um ano.

SATOMI et al. ${ }^{73}$ em 1988 publicaram um artigo no qual foi avaliado o efeito da irrigação sobre o grau de osseointegração. Foram colocados 8 implantes em cada macaco da amostra, sendo 2 revestidos por óxido de titânio $\left(\mathrm{TiO}_{2}\right)$. Os implantes foram inseridos utilizando-se 
irrigação em somente $50 \%$ dos casos e após 3 meses os animais foram sacrificados. As amostras foram preparadas histologicamente para uma avaliação por morfometria computadorizada. Os implantes de titânio revestidos por óxido de titânio $\left(\mathrm{TiO}_{2}\right)$ apresentaram valores de contato ósseo direto de $29 \%$ sem uso de irrigação e $74,5 \%$ utilizando a irrigação. Os implantes sem revestimento $\left(\mathrm{TiO}_{2}\right)$ apresentaram valores contato ósseo direto de $28,9 \%$ sem uso da irrigação e $68,4 \%$ utilizando a irrigação, o que levou a concluir que os implantes revestidos ou não por óxido de titânio $\left(\mathrm{TiO}_{2}\right)$ não apresentaram diferenças quanto ao percentual de osseointegração quando inseridos sob irrigação, sendo que os implantes inseridos sem utilização da irrigação apresentaram baixo índice de osseointegração.

No estudo apresentado em 1988 por PARR et al. ${ }^{66}$ foram analisados 4 implantes que demonstraram insucesso, tendo sido removidos de 3 pacientes. Os implantes permaneceram no local por períodos de tempo que variaram de 3 a 13 meses e foram removidos devido à dor, mobilidade ou infecção, sendo fixados em formalina a 10\%. As amostras foram embebidas em polimetilmetacrilato, seccionadas e coradas com fucsina básica e azul de toluidina. Sua análise mostrou uma grande variedade da resposta tecidual em toda a extensão ápico-coronal. Os cortes da região apical apresentaram uma adaptação óssea ao implante aceitável com pouca ou nenhuma interposição de tecido conjuntivo. À medida que os cortes progrediram coronalmente, o tecido 
conjuntivo interposto alargou-se frouxamente arranjado e alinhou-se paralelamente à superfície do implante. A região mais coronal do tecido ósseo apresentou necrose, ulceração e hemorragia. Os resultados obtidos sugeriram que o trauma cirúrgico durante a inserção e uma falha da regeneração vascular foram as causas dos insucessos.

Em artigo publicado em 1988, BRUNETTE ${ }^{17}$ realizou uma abrangente revisão sobre 0 comportamento celular durante a fase cicatricial, após a inserção do implante, ressaltando a importância de 4 fenômenos do comportamento celular, que foram previamente observados in vitro, e que também parecem ser efetivos in vivo (guia por contato, rugofilia, efeito de dois centros e haptotaxia). O fato da guia por contato ocorrer in vivo estaria claramente indicado pela orientação das fibras nos sulcos circulares dos implantes Tuebingen. Apesar das superfícies rugosas não apresentarem efeitos danosos a longo prazo sobre a performance dos implantes, algumas evidências sugeriram que os macrófagos apresentariam rugofilia in vivo porque seriam atraídos por superfícies rugosas. A orientação das células do tecido conjuntivo e fibras adjacentes às superfícies porosas poderia ser explicada pelo efeito dos dois centros. Por outro lado, a haptotaxia pode estar envolvida na formação de cápsula de tecido fibroso ao redor de implantes com baixa energia superficial. Como conclusão, o autor afirmou que da mesma forma que os avanços na ciência dos materiais dos implantes modernos beneficiaram suas confecções, as interações célula-implante in vivo 
permitiriam a melhora da topografia superficial dos implantes no futuro.

Em 1988, LINDQUIST et al. ${ }^{60}$ avaliaram a reabsorção óssea ao redor de 276 implantes mandibulares inseridos em 46 pacientes. Vinte e cinco pacientes foram avaliados por $51 / 2$ a 6 anos, e 21 pacientes foram avaliados por 3 a 4 anos. As radiografias estereoscópicas foram realizadas 1,6 e 12 meses após a inserção e a cada 2 meses subseqüentes. Os pacientes também foram avaliados quanto à higiene bucal, ao desgaste oclusal e ao apertamento dental durante a evolução do estudo. Observaram durante o estudo uma pequena reabsorção óssea (aproximadamente $0,5 \mathrm{~mm}$ ) durante 0 primeiro ano pós-cirúrgico e 0,06 a $0,08 \mathrm{~mm}$ anualmente a partir do segundo ano. A higiene bucal deficiente bem como o apertamento dental influenciaram de maneira significativa a perda óssea. Uma maior perda óssea foi observada nos implantes medianos do que nos implantes posteriores.

Ainda no ano de 1988, JOHANSSON; JACOBSSON; ALBREKTSSON $^{46}$, utilizando 26 coelhos, inseriram 104 implantes de Ti cp (Brånemark) nas tíbia e fêmur dos animais para avaliação do grau de contato ósseo obtido após diferentes intervalos de tempo. Os implantes foram preparados por lavagem com detergente e álcool em ultra-som, seguida de autoclavagem. As amostras foram obtidas 21, 30, 90, 180 e 360 dias após a inserção, sendo que um implante foi removido por torquímetro e o outro contendo o implante e o tecido circundante foi 
removido em bloco para análise histológica. O torque necessário para remoção após 21 dias foi de $11 \mathrm{Ncm}$ na tíbia e $29 \mathrm{Ncm}$ no fêmur. Aos 90 dias o torque obtido foi de $68 \mathrm{Ncm}$ na tíbia e $61 \mathrm{Ncm}$ no fêmur. Após 360 dias a média do torque de remoção foi de $88 \mathrm{Ncm}$ na tíbia e $85 \mathrm{Ncm}$ no fêmur. A análise por microscopia ótica demonstrou a presença de ecido mole na interface osso/implante no período de 21 dias. Aos 90 dias a quantidade de contato osso/implante foi maior na tíbia do que no fêmur. Após 360 dias a tíbia e o fêmur apresentaram média de contato direto osso/implante acima de $90 \%$. Os dados obtidos sugeriram que 0 aumento da força necessária para a remoção dos implantes em função do tempo podia ser explicado pelo aumento da quantidade de osso na interface.

Em 1989, RIEGER et al. ${ }^{70}$ avaliaram 3 diferentes tipos de implantes em relação aos revestimentos bioativos e seu papel no aumento da união do osso ao implante. Foi utilizada a análise de elemento finito para avaliar se a união óssea ou a adaptação óssea (osseointegração) seria bioquimicamente benéfica. Os resultados demonstraram que, apesar de uma interface unida entre o implante e o tecido hospedeiro poder ser bioquimicamente benéfica, a união óssea pode não ser biomecanicamente benéfica para o implante ou para o osso circundante. Os autores demonstraram a geração de uma grande quantidade de "stress" quando uma força era aplicada sobre um implante com revestimento bioativo. Também afirmaram que nem os cirurgiões- 
dentistas nem os fabricantes deveriam assumir que revestimentos bioativos ou a união óssea em geral melhoram o prognóstico biomecânico dos implantes endósseos.

Nesse mesmo ano, KELLER; GROTENDORST; DOUGHERTY ${ }^{51}$ avaliaram a capacidade de adesão celular sobre o titânio puro. Para tanto, utilizaram discos de titânio que, após passarem por um processo de polimento, foram limpos em solvente, lavados, passivados por ácido nítrico a $30 \%$, enxaguados em água destilada e esterilizados em autoclave, óxido de etileno ou imersão em álcool etílico a 100\%. Após a realização dos procedimentos de limpeza e esterilização os discos foram imersos em um meio de cultura para fibroblastos por uma hora. Como controle, foram utilizados plásticos tratados para adesão celular (60 minutos $=96 \%$ adesão). Após 60 minutos os índices de adesão celular observados foram de $76 \%$ para os discos esterilizados em óxido de etileno, $82 \%$ para os discos esterilizados em autoclave e $75 \%$ para esterilização em álcool etílico. Algumas observações por microscopia eletrônica de varredura demonstraram que a difusão celular foi inibida em algumas áreas das superfícies esterilizadas quando comparadas com as superfícies passivadas. Os dados mostraram que alguns procedimentos de esterilização podem afetar a resposta biológica dos tecidos aos implantes.

MICHAELS $^{64}$, em 1989, publicou um estudo comparativo com a finalidade de avaliar a capacidade de adesão celular sobre 
superfícies de titânio com vários graus de rugosidade,. As amostras de titânio foram preparadas com polimento com pasta diamantada de $1 \mu \mathrm{m}$ (superfície lisa), lixadas com papel de sílica granulação 600 ou jateadas (superfície rugosa). Os espécimes foram limpos em solvente, lavados, passivados e enxaguados em água deionizada. Meios de cultura contendo fibroblastos de ratos foram incubados sobre várias superfícies de titânio (lisas e rugosas) por mais de 2 horas. Utilizando cultura de tecido em plástico como controle da adesão celular, o número de células que não aderiram foi quantificado e a porcentagem de células aderidas foi calculada. Após 15 minutos a adesão celular e os fibroblastos do ligamento periodontal apresentaram maiores índices sobre as superfícies lisas (41\%) e menores índices nas superfícies rugosas (21\%). Após 2 horas, a adesão celular foi a mesma para as duas superfícies e o controle (@80\%). Em relação aos osteoblastos, após 15 minutos a adesão celular foi a mesma para superfícies lisas e rugosas (30\%). Entretanto, após 2 horas, os índices de adesão celular foram de 63\% para as superfícies rugosas, $64 \%$ para o controle plástico e $47 \%$ para as superfícies lisas. Diante das evidências observadasooo, os autores sugeriram haver diferentes respostas frente as variações de rugosidade superficial, o que poderia influenciar a resposta biológica mediante a inserção de um implante.

Procurando avaliar as possíveis vantagens do tratamento de implantes de titânio com plasma de titânio em relação ao tratamento 
convencional, CARLSSON; ALBREKTSSON; BERMAN ${ }^{23}$ realizaram um estudo em 1989. Um total de 84 implantes foi inserido na tíbia e fêmur de 21 coelhos adultos. De um lado foram inseridos implantes com plasma de $\mathrm{Ti}$ enquanto do outro lado os implantes convencionais serviram como controle. Todos os implantes foram lavados com etanol e butanol e então autoclavados. No grupo A os implantes (22) foram inseridos 2 minutos após a aplicação do plasma. No grupo B, 20 implantes tratados com plasma foram imediatamente imersos em água tridestilada para alcançarem estado de alta energia superficial. Os implantes mantiveramse úmidos, expostos à atmosfera por menos de 30 segundos e implantados em 10 minutos. No grupo C, 42 implantes foram somente lavados e autoclavados. Os implantes foram removidos com o auxílio de um torquímetro 6 semanas após a inserção. Dois animais de cada grupo foram utilizados para análise histológica. Os resultados apresentaram torque médio de $18 \mathrm{Ncm}$ no fêmur e $16 \mathrm{Ncm}$ na tíbia para o grupo A, 19 $\mathrm{Ncm}$ no fêmur e $17 \mathrm{Ncm}$ na tíbia para o grupo B e $22 \mathrm{Ncm}$ no fêmur e 17 Ncm na tíbia para o grupo C (controle). Os autores concluíram que o tratamento convencional descrito é suficiente para fornecer condições superficiais para uma resposta cicatricial inicial, semelhantes àquelas observadas no implante com plasma de Ti.

Em abrangente artigo de revisão sobre osseointegração publicado em 1990 por ALBREKTSSON; SENNERBY ${ }^{5}$ este termo foi analisado em relação às suas definições clínicas e teóricas além de ser 
comparado com outras formas de implante. Para os autores, o termo osseointegração denotaria significado clínico claro, mas existiriam dúvidas quanto ao seu uso em condições experimentais. Clinicamente, um implante poderia ser descrito como osseointegrado se não houvesse algum movimento discernível quando uma força é aplicada sobre o mesmo. Esta característica estaria em contraste com os implantes circundados por tecido conjuntivo fibroso, os quais apresentariam movimentação no interior do tecido mole. Técnicas laboratoriais recentemente desenvolvidas poderiam ser usadas no futuro para caracterizar precisamente a osseointegração. Ressaltaram que o termo osseointegração deveria ser sempre empregado com muito cuidado, e nunca em situações experimentais. Da mesma forma, os autores estabeleceram 10 exigências mínimas para que um implante pudesse ser clinicamente acompanhado com confiança.

Em 1990, BUSER et al. $^{20}$ publicaram um estudo no qual se avaliou a possibilidade de formação de cemento com fibras colágenas inseridas sobre a superfície de implantes de Ti cp. Implantes cilíndricos ITI recobertos por plasma de titânio foram inseridos na mandíbula de macacos em regiões onde porções radiculares apicais ficaram retidas no processo alveolar. Após 12 meses as peças foram processadas histologicamente em cortes não desmineralizados. Nas áreas onde os implantes foram colocados em contato com o ligamento periodontal das raízes retidas, pode-se observar a formação de um leito de tecido duro 
sobre regiões das superfícies dos implantes, o qual apresentava continuidade com 0 cemento recém-formado sobre as raízes subjacentes. O cemento formado sobre os implantes apresentou um ligamento periodontal que o separava do osso. Entretanto, não se observou ligamento periodontal em torno de implantes colocados em contato direto com fragmentos radiculares cortados ou quando colocados em áreas sem raízes retidas.

Em 1990, DAVIES; LOWENBERG; SHIGA ${ }^{27}$ avaliaram as características morfológicas da interface osso/metal usando discos de $\mathrm{Ti}$ $\mathrm{cp}$ polidos, lavados por água bidestilada, passivados por 1 hora em ácido nítrico e autoclavados. Os discos foram colocados em meio de cultura contendo células da medula óssea de ratos adultos jovens. Este estudo foi realizado para confirmar a possibilidade de avaliação dos mecanismos de cicatrização da interface em cultura e, segundo os autores, os resultados demonstraram claramente que tecido semelhante ao osso pode crescer sobre discos de Ti cp.

Em artigo publicado em 1990, DONOHUE; MASCRÈS ${ }^{31}$ avaliaram os efeitos de aplicação de hidroxiapatita sobre as cabeças de implantes expostas no fêmur de 38 coelhos. Após 6 meses a aposição óssea foi avaliada por exame visual e microscopia eletrônica de varredura. Apesar de ser observado osso em contato direto com as cabeças dos implantes, as extremidades dessas cabeças estavam envolvidas por tecido conjuntivo. Comparando-se com os animais de 
controle, a aplicação de colágeno de hidroxiapatita densa não aumentou a área de osteogênese. Quando os implantes penetraram no osso através de blocos de colágeno/hidroxiapatita previamente colocados, houve diminuição da quantidade de osso unida ao corpo dos implantes em comparação com os controles, sugerindo que o uso de hidroxiapatita densa não aumentaria a quantidade de tecido ósseo formado ao redor dos implantes de titânio.

Nesse mesmo ano, DEPORTER et al. $^{30}$ publicaram um estudo no qual compararam implantes cônicos porosos de $\mathrm{Ti}_{6} \mathrm{Al}_{4} \mathrm{~V}$ e implantes cilíndricos rosqueados de titânio puro. Seis cães beagle receberam 2 implantes porosos de um lado da mandíbula e 2 implantes rosqueáveis do lado oposto. Cada grupo de dois implantes suportou uma prótese fixa de dois elementos por um período funcional de 18 meses. Através da utilização de morfometria computadorizada foi avaliada a extensão da superfície do implante em contato direto com o osso, em cada face dos mesmos. Observaram que quando a extensão de contato absoluto foi relacionada com a altura óssea vertical correspondente, algumas diferenças foram notadas, sendo que a extensão de contato absoluto foi maior para qualquer altura óssea observada para os implantes porosos. Os dados, segundo os autores indicaram que implantes mais curtos poderiam ser usados com um desenho de superfície porosa com mais segurança.

Em 1990 foi publicado um estudo realizado por KLAUBER; 
LENZ; HENRY ${ }^{54}$ no qual os autores caracterizaram a contaminação superficial e mediram a composição e espessura da camada de óxido de titânio de 6 implantes diferentes. Como método de análise foi utilizada a espectroscopia eletrônica por análise química devido a sua sensibilidade e habilidade para detectar todos os elementos com número atômico maior que 2. Foram observados em todos os implantes diferentes níveis de $\mathrm{C}$ e $\mathrm{Na}$. Além disso, a presença de N, F, Mg, Si, Cl, $\mathrm{Ca}, \mathrm{Mn}, \mathrm{Cu}, \mathrm{Ag}$ e As foi detectada em muitos implantes. De todos os tipos de implantes observados (Core-Vent, Screw-Vent, Brånemark, Sterioss, IMZ e Osseodent), a mínima oxidação se deu (20 Å) nos implantes Core-Vent, Screw-Vent e Brånemark, enquanto os níveis mais baixos e contaminação foram observados nos implantes Sterioss, IMZ e Brånemark.

Em artigo publicado em 1990, PILLIAR $^{68}$ descreveu as características comuns a todos os implantes dentais utilizados. Entre estas observou: 1) o uso de materiais biocompatíveis, 2) a necessidade de um período de ausência de função para permitir ao implante uma fixação rígida ("osseointegração"), 3) um desenho que evitasse a perda óssea crônica devido a fatores mecânicos ou bioquímicos. O autor afirmou ainda a ausência de um implante dental com um formato claramente superior aos demais, salientando que os pesquisadores precisam desenvolver um implante que possa ser colocado com procedimentos mais simples, seja confiável e possa ser utilizado em 
situações críticas (por exemplo: altura óssea alveolar reduzida) e seja relativamente barato, tornando seu uso mais universal. Foi também relatada a necessidade de estudos básicos e avançados como fatores essenciais para alcançarmos esses objetivos anteriormente citados.

KELLER et al. ${ }^{50}$ avaliaram em 1990 a superfície de discos de titânio $\mathrm{cp}$ lixados e polidos com papéis metalográficos, sendo posteriormente lavados em cetona metilmetacrilato e água destilada, sofrendo passivação em ácido nítrico $30 \%$ por 30 minutos. Um último banho em água destilada à temperatura ambiente e à vácuo foi realizado. Após este tratamento, as peças foram esterilizadas em autoclave, óxido de etileno ou imersão em etanol absoluto. Várias amostras foram preparadas através de passivação com ácido e água destilada e não foram esterilizadas, servindo como controle. Os autores puderam observar um aumento da espessura da camada de óxido comparada com superfícies não estéreis.

Um complexo estudo realizado em 1990 por LAUSMAA; KASEMO; MATTSON ${ }^{57}$ buscou caracterizar a composição química da superfície de implantes de $\mathrm{Ti} \mathrm{cp}$. Os principais métodos de caracterização empregados foram: espectroscopia por fotoemissão de raios-x (XPS ou ESCA) para análise da composição química superficial e espectroscopia eletrônica de Auger (AES) para análise da composição e concentração do perfil da profundidade dos elementos superficiais. Informações adicionais foram obtidas através de espectroscopia de 
massa de íons secundários dinâmicos (SiMS), fluorescência radiográfica por energia dispersiva (EDAX) e perfil do hidrogênio por microanálise nuclear (NMA). Após a usinagem das peças em forma de parafuso ou retangular em $\mathrm{Ti} \mathrm{cp}$, as amostras foram lavadas e esterilizadas em autoclave, calor seco ou embaladas em ampolas de vidro lacradas e esterilizadas. Através de análise por espectroscopia de fotoemissão de raios- $\mathrm{X}$, em todas as amostras, estéreis ou não, foi observada a presença de $\mathrm{Ti}, \mathrm{O}, \mathrm{C}, \mathrm{N}$ e $\mathrm{Ca}$. Ocasionalmente foram encontrados traços de $\mathrm{S}, \mathrm{Cl}$, P. $\mathrm{Si}, \mathrm{Na}, \mathrm{Cu}, \mathrm{Zn}, \mathrm{Sn}$ e $\mathrm{Pb}$. As amostras embaladas estéreis mostraram níveis de $\mathrm{C}$ mais reduzidos e menor variação do que as amostras não estéreis. Isto provavelmente ocorreu devido ao controle da contaminação proporcionado pelas ampolas seladas, o que preveniu a exposição ao ar. De acordo com os autores, na esterilização ocorria aumento na espessura da camada de óxido, não havendo diferença significativa entre a espessura de óxido das amostras esterilizadas por calor seco ou úmido. Os autores concluíram que a fina superfície de óxido é coberta por uma camada de contaminantes de composição complexa.

Em 1991 UEDA et al. ${ }^{82}$ avaliaram a relação entre o torque de inserção e o torque de remoção. Na primeira parte do estudo os autores utilizaram 2 ossos temporais obtidos de cadáver fresco. A área cirúrgica foi separada em duas regiões distintas, sendo uma bicortical e outra unicortical, nas quais foram inseridos implantes de latão, pois a proposta do estudo foi avaliar as características das roscas ósseas. Os 
implantes foram inseridos com torques que variaram entre $20,30,40,50$, 60 e $70 \mathrm{Ncm}$ e imediatamente após a inserção, o implante foi desparafusado e o torque de remoção foi medido com o mesmo torquímetro. Na segunda parte do estudo, 3 implantes foram inseridos nos processos mastóides de humanos vivos e de cadáver, os quais foram removidos junto com os implantes e analisados histologicamente. O torque de inserção foi medido no aperto final do implante e o torque de remoção foi medido enquanto a mesma fixação era desparafusada. Os autores observaram que o torque de inserção máximo sem causar fratura nas roscas ósseas foi de $70 \mathrm{Ncm}$ no osso bicortical e $50 \mathrm{Ncm}$ em osso unicortical. O torque de remoção foi sempre menor que o de inserção em todas as medidas, porém houve entre eles uma correlação positiva. Entretanto, o ponto de fratura nas roscas ósseas foi em média de 77 $\mathrm{Ncm}$ em osso bicortical e $57,7 \mathrm{Ncm}$ em osso unicortical. As microfraturas foram observadas principalmente nas roscas da base. Os autores concluíram que, se o cirurgião exercer pressão exagerada sobre 0 implante, uma compressão contínua é adicionada ao osso circundante e especialmente sobre as roscas.

Nesse mesmo ano, JOHANSSON; SENNERBY; ALBREKTSSON $^{47}$ compararam a força de torque necessária para remoção de implantes fabricados em $\mathrm{Ti} \mathrm{cp}$ e Vitallium. $\mathrm{O}$ total de 7 coelhos recebeu 4 implantes cada, sendo 2 de Ti cp e 2 de Vitallium, com inserção unicortical. Após 3 meses foram realizadas análises de torque 
para remoção e histológica. Os autores observaram que a força de torque necessária para remoção dos implantes de $\mathrm{Ti} \mathrm{cp}$ foi em média $24,9 \mathrm{Ncm}$, enquanto que para os implantes de Vitallium foi de $11,7 \mathrm{Ncm}$. Pela análise histométrica os autores constataram que a média de contato osso-metal para os implantes de $\mathrm{Ti} \mathrm{cp}$ foi de $34,7 \%$ enquanto para os implantes de Vitallium a média foi de 21,7\%.

Com a finalidade de avaliar a influência de diferentes características superficiais dos implantes em relação à osseointegração, BUSER et al. $^{19}$ publicaram um estudo em 1991 no qual implantes cilíndricos ocos com 6 diferentes superfícies foram inseridos na metáfise da tíbia e fêmur de 6 roedores. Após 3 e 6 semanas, os implantes e o osso circundante foram removidos e analisados em cortes histológicos transversais não descalcificados. $\mathrm{O}$ exame histológico demonstrou contato direto entre osso e implante para todas as superfícies avaliadas. Entretanto, a análise morfométrica demonstrou diferenças significantes no percentual de contato osso/implante, quando foi avaliado o osso medular. As superfícies dos implantes eletropolidos (E) e jateados com a área de granulação média e conservadas em ácido (SMA) apresentaram o percentual mais baixo de contato entre implante e osso, com valores situados entre 20 e $25 \%$. Os implantes jateados com areia grossa (SL) e os implantes com plasma de titânio apresentaram valores entre 30 e $40 \%$ de contato com o osso. O maior grau de contato implante/osso foi observado em implantes jateados com areia grossa e atacados por ácido 
(SLA) com valores entre 50 e $60 \%$ e implante com plasma de hidroxiapatita com valores entre 60 e $70 \%$. Entretanto, o revestimento de hidroxiapatita apresentou sinais de reabsorção. Concluiu-se que o percentual de contato entre osso e implante está diretamente relacionado com aumento da rugosidade da superfície do implante.

PILLIAR et al. ${ }^{67}$ avaliaram o remodelamento ósseo ao redor de 3 diferentes tipos de implantes, em diferentes intervalos de tempo, histológica e radiograficamente. Os implantes foram inseridos em mandíbulas de cães e divididos em 3 grupos: A) implante de $\mathrm{Ti}$ cp em forma de parafuso, B) implante cônico de liga de $\mathrm{Ti}$ com poros superficiais e C) implante cônico de liga de Ti com poros apenas nos 2/3 apicais. Os implantes do grupo B foram mantidos em função por até 23 semanas, enquanto que os implantes do grupo $A$ e $C$ foram mantidos em função por no máximo 73-77 semanas. A avaliação radiográfica foi realizada periodicamente durante 0 tempo em que os implantes estiveram em função. Pode-se verificar que os implantes do grupo $A$ encontravam-se osseointegrados com a presença de osso em toda a extensão do implante. Estatisticamente, ocorreu variação no crescimento ósseo em relação ao tempo. Nos implantes do grupo B ocorreu crescimento ósseo 4 semanas após a inserção. No grupo $C$ houve crescimento coronal (sem porosidade), pequena quantidade de osso formou-se próximo à superfície em algumas amostras. Ocorreu alguma perda óssea marginal no primeiro ano apenas para os implantes em 
forma de parafuso e nos parcialmente cobertos, porém, limitada à região dos implantes. Os autores concluíram que a modificação na transferência de cargas para o osso circunjacente ao implante pode causar alterações significativas na estrutura óssea. Os autores também sugeriram recobrir coronalmente o implante com material poroso para evitar a perda óssea inicial.

Em 1992, BOWERS et al. $^{13}$ estudaram a influência da rugosidade superficial do titânio com relação à aderência de células osteoblásticas. Discos de $\mathrm{Ti} \mathrm{cp}$ foram preparados para apresentarem superfície regulares e irregulares. As amostras com morfologia irregular foram polidas usando papel metalográfico de granulação 600 e a seguir jateados com $\mathrm{Al}_{2} \quad \mathrm{O}_{3}$ em partículas de $50 \mu \mathrm{m}$ ou condicionadas por ataque ácido com $\mathrm{HF} 3,5 \% / \mathrm{HNO}_{3} 25 \%$ por 1,5 ou 10 minutos. As superfícies com morfologia regular foram produzidas usando papel metalográfico de granulação 60 ou 120. O grupo controle foi polido usando-se papel de granulação 600 para fazer a medida da rugosidade no perfilômetro. Todas as amostras foram limpas em solvente, lavadas em água destilada, passivadas com ácido nítrico e submetidas à lavagem final em água destilada, sendo secas à vácuo. Utilizando o perfilômetro, os autores avaliaram a rugosidade superficial. A adesão celular foi avaliada em meios de cultura com células da calvária de ratos e as características morfológicas das células, em função das diferentes superfícies e intervalos de tempo, foram avaliadas por microscopia 
eletrônica de varredura. A superfície irregular produzida pelo jateamento demonstrou ser mais condutiva para a aderência celular do que a superfície rugosa produzida pelo polimento e lixamento ou ataque ácido. Níveis significativamente mais altos de aderência celular foram encontrados nas superfícies jateadas.

Com a finalidade de quantificar o osso em contato com três diferentes tipos de implantes, WEILANDER et al. ${ }^{83}$ publicaram um artigo em 1992. Três implantes disponíveis comercialmente (Nobelpharma, IMZ e Integral) foram inseridos em mandíbulas edêntulas de 7 cães. Vinte e um implantes foram removidos com o osso circunjacente 3 meses após a sua inserção, sendo então embebidos em resina de polimetilmetacrilato para preparo de cortes histológicos por desgaste. O percentual de contato ósseo com as superfícies dos implantes foi medido por um método de histomorfometria desenvolvido pelos autores, utilizando uma grade milimetrada em um estereomicroscópio. Dois implantes utilizados possuíam superfícies de titânio (Nobelpharma e IMZ) e um deles possuía uma camada externa de hidroxiapatita. Os resultados demonstraram que houve a formação de um percentual significativamente maior de osso ao redor dos implantes revestidos por hidroxiapatita quando comparados com os implantes de titânio puro (Brånemark) ou plasma de titânio (iMZ).

SENNERBY; THOUSEN; ERICSSON ${ }^{74}$, em 1992, avaliaram a força de torque para remoção de 128 implantes de titânio 
puro em forma de parafuso inseridos na tíbia de coelhos e na porção femoral da articulação do joelho> Avaliou-se também a morfometria dos cortes histológicos 6 semanas, 3 meses e 6 meses após a inserção. Os implantes intraarticulares na porção femoral apresentaram osso mais medular, enquanto os implantes da tíbia formaram osso cortical. O torque necessário para remoção dos implantes intraarticulares aumentou em relação ao intervalo de tempo, porém não houve aumento para os implantes da tíbia. Após 6 semanas, um torque significativamente menor foi necessário para remoção dos implantes intraarticulares, porém mais osso foi observado nas roscas desses implantes quando comparados aos implantes da tíbia. Quando foi calculada a quantidade de osso nas roscas situadas no osso cortical uma maior quantidade foi observada nas roscas dos implantes inseridos na tíbia, o que correspondeu a um torque de remoção maior. Os achados sugeriram que a resistência à remoção é dependente da quantidade de osso compacto ao redor do implante de titânio.

Buscando avaliar a formação do coágulo in vivo sobre a superfície de titânio puro e sobre a superfície de titânio revestida por hidroxiapatita, STEINBERG; WILLEY; DRUMMOND ${ }^{78}$ realizaram um interessante estudo de 1992. Imediatamente após às exodontias, 80 implantes (40 de cada grupo) foram inseridos no coágulo sangüíneo que formou-se no interior dos alvéolos por 1, 30, 60 ou 120 segundos. Observações sobre a topografia do coágulo foram realizadas através de 
microscopia eletrônica de varredura. Nenhuma das superfícies dos implantes apresentou grandes diferenças no grau de formação do coágulo durante os 120 segundos de inserção, revelando uma formação precoce do mesmo, porém, com uma adesão limitada. Estes resultados foram comparados com um estudo prévio, no qual a mesma metodologia foi utilizada em relação ao ligamento periodontal intacto, a raízes raspadas e a raízes tratadas com ácido cítrico pH 1,0. A superfície com ligamento periodontal intacto foi a que apresentou a mais rápida formação de coágulo. Os dados obtidos sugeriram que a velocidade de formação do coágulo é sensivelmente menor em superfícies artificiais quando comparadas às superfícies radiculares.

Em um estudo publicado em 1992 por STEFLIK et al. ${ }^{75}, 8$ implantes de titânio, rosqueados nas mandíbulas de 4 cães adultos, foram avaliados em relação ao crescimento e aposição óssea. Os implantes foram removidos 5 meses após a inserção com uma quantidade de osso ao redor para avaliação histológica. A análise histológica foi realizada por microscopia eletrônica de transmissão convencional de alta voltagem e microscopia ótica, o que demonstrou uma dinâmica interface osso/implante. Um tecido mineralizado foi observado de forma rotineira distante 20 a $50 \mu \mathrm{m}$ da superfície do implante e separado da interface do implante por uma camada elétrondensa. Uma matriz de fibras colágenas densamente mineralizadas encontrava-se orientada paralelamente à interface do implante, assim 
como os osteócitos observados próximas à interface. Projeções osteocíticas através de canalículos geralmente direcionadas para a superfície do implante, também foram observadas. Os autores concluíram que a interface osso/implante é extremamente dinâmica e apresentaria um osso saudável sobre a superfície de titânio.

No ano de 1992, BUDD et al. ${ }^{18}$ avaliaram 8 implantes que foram inseridos na porção cortical do osso frontonasal de suínos, sendo removidos 6 meses após a inserção. Os implantes foram removidos em bloco, desidratados e imersos em resina de baixa viscosidade. As amostras foram analisadas por microscopia eletrônica de varredura, microscopia eletrônica de transmissão e por análise radiográfica de alta resolução por energia dispersiva. Estas avaliações combinadas sugeriram, segundo os autores, que os depósitos amorfos observados na interface osso/implante continham titânio e altas concentrações de cálcio e fósforo, levando a concluírem que o uso de resina de baixa viscosidade para a inclusão das peças histológicas poderia apresentar melhor penetração na camada de óxido de titânio, facilitando a análise da interface.

Procurando comparar a composição da superfície de implantes semelhantes ao sistema Brånemark, BINON; WEIR; MARSHALL $^{12}$ publicaram um extenso estudo em 1992. Foram avaliados 4 tipos de implantes através de análise de superfície microanalítica, sendo eles NobelPharma, Core-Vient, Osseodent e Implant Innovations. 
As amostras foram submetidas à análise por EDX (espectroscopia radiográfica por energia dispersiva) e AES (espectroscopia eletrônica de Auger). Por meio das análises, os autores afirmaram que os 4 implantes avaliados foram obtidos de blocos de titânio comercialmente puros. Os resultados demonstraram que cada um dos implantes avaliados apresentou um variado grau de contaminação superficial. O grau de limpeza superficial mais alto foi obtido pelo implante Osseodent, seguido dos implantes NobelPharma, Implant Innovations e Core-Vent em ordem decrescente. Os autores salientaram que as substâncias contaminadas seriam provenientes das máquinas utilizadas na fabricação e recomendaram o uso rotineiro da análise superficial para obtenção de uma superfície biologicamente limpa e aceitável para a implantação.

Neste mesmo ano, GOTTLANDER; ALBREKTSSON; CARLSSON $^{37}$ publicaram um estudo no qual uma avaliação histomorfométrica foi realizada para comparar a quantidade de osso na interface de implantes cilíndricos revestidos por hidroxiapatita ou por titânio. Dezoito implantes foram inseridos no fêmur de 9 coelhos adultos, sendo removidos em bloco com o osso circunjacente 6 meses após a inserção. Uma análise histomorfométrica foi realizada para que fosse calculado o percentual de contato direto entre o osso e o implante. $O$ percentual de contato ósseo na região medular foi de $75,9 \%$ para implantes revestidos por hidroxiapatita e de 59,9\% para implantes revestidos por titânio, em média. O percentual de contato ósseo na 
região cortical foi de $80,2 \%$ para implantes revestidos por hidroxiapatita e de $69,4 \%$ para implantes revestidos por titânio, em média. Os dados sugeriram a ocorrência de uma maior formação óssea nos implantes cilíndricos revestidos por hidroxiapatita, porém os autores ressaltaram que para os implantes rosqueáveis estes resultados não foram observados em um estudo prévio. Afirmam ainda que o papel da hidroxiapatita pode ser importante para os implantes cilíndricos lisos devido à instabilidade inicial.

Em 1993, HAIDER; WATZEK; PLENK ${ }^{38}$ JUNIOR avaliaram a afetividade da irrigação interna ou externa em relação ao comportamento do tecido ósseo, através de microscopia in vivo. Doze implantes IMZ foram inseridos na tíbia de 6 ovelhas. Cada par de implantes foi inserido, sendo que um dos implantes foi colocado utilizando irrigação interna e outro irrigação externa. Os animais foram sacrificados 4, 8 e 16 semanas após a inserção, sendo que o crescimento ósseo sofreu marcação polifluorocrômica seqüencial. Esta marcação foi realizada com doses subcutâneas de tetraciclina 14 dias após a inserção, alizarina no período médio da fase cicatricial e calceína 4 dias antes do sacrifício dos animais. Baseado no percentual de osso recém-formado em contato com o implante, a irrigação externa demonstrou maior efetividade em todas as perfurações do osso compacto e esponjoso superficial, enquanto a irrigação interna foi superior somente no osso compacto profundo. Os autores afirmaram que 
um sistema de implantes deveria apresentar irrigação interna e externa como alternativa para resfriamento durante as perfurações ósseas.

Em estudo publicado em 1993, ETTINGER et al. ${ }^{35}$ procuraram desenvolver uma metodologia para avaliação da cicatrização óssea ao redor de 15 implantes IMZ inseridos em alvéolos de dentes recém-extraídos de 3 cães adultos. Além dos implantes, cada animal teve uma área receptora preparada sem que houvesse a inserção do implante (região controle). Hidroxiapatita porosa foi colocada circundando a metade inferior de 2 implantes, um dos quais foi coberto por uma membrana de politetrafluoretileno. Após 12 semanas, os animais foram sacrificados e suas mandíbulas foram removidas para obtenção dos implantes com o osso circunjacente e, posteriormente, foram embebidos em resina. Cortes longitudinais e transversais seriados foram realizados e posteriormente desgastados até uma espessura entre 50 e $100 \mu \mathrm{m}$. Os cortes foram então corados por hematoxilina-eosina, alizarina e toluidina. Fotomicrografias padronizadas foram obtidas de modo que o contato da interface osso/implante pudesse ser medido por um digitador sônico. 0 percentual médio de contato ósseo com o implante em cortes longitudinais foi de $47,9 \% \pm 5,2 \%$. Os cortes transversais apresentaram contato ósseo médio de $53,5 \% \pm 3,7 \%$. Os autores sugeriram que este estudo piloto demonstrou que os implantes IMZ inseridos em alvéolos de dentes recém-extraídos apresentaram um íntimo contato com o osso, porém grande variação na quantidade de osso foi observada em um 
mesmo animal.

Neste mesmo ano, PARR; STEFLIK; SISK ${ }^{65}$ procuraram avaliar a cicatrização óssea através de análise histológica e histomorfométrica ao redor de 13 implantes de titânio rosqueáveis (Sterioss) inseridos na maxila e mandíbulas de 3 cães adultos imediatamente após exodontia dos pré-molares. Os implantes inseridos na mandíbula apresentaram a maior quantidade de aposição óssea, com uma média de $60,3 \%$. Os implantes localizados na maxila apresentaram uma menor aposição óssea, com uma média de 46,3\%. Os valores obtidos para o crescimento ósseo 5 meses após a inserção nas regiões de controle foram consistentes com aqueles obtidos para o osso que se formou ao redor dos implantes no mesmo intervalo de tempo. Os autores observaram que os valores obtidos para o crescimento ósseo nas áreas preparadas para receber os implantes foram maiores do que nas áreas em que foram apenas realizadas as exodontias (controle). Os autores sugeriram que a inserção de implantes imediatamente após a exodontia demonstra potencial para ocorrência de uma boa aposição óssea, dependendo da região a ser implantada.

Buscando desenvolver um método para avaliação das relações existentes entre os implantes de titânio inseridos no osso e as populações de células imunes e hematopoiéticas, RAHAL; BRÅNEMARK; OSMOND ${ }^{69}$, em 1993, utilizaram implantes miniaturizados na diáfise do fêmur de ratos. Após a inserção dos implantes, os animais 
foram sacrificados com intervalos de 1, 2, 3, 4 e 18 semanas e as peças histológicas preparadas para avaliação por microscopia ótica e microscopia eletrônica de varredura. A análise histológica demonstrou contato direto do osso com a superfície do implante apresentando a primeira evidência de osseointegração em ratos. Além disso, uma extensa superfície apresentou-se diretamente em contato com a medula óssea regenerada, condição que permaneceu até a $18^{\mathrm{a}}$ semana após a inserção dos implantes. Algumas células da medula óssea, que formavam uma camada incompleta em contato com a interface de titânio possuíam características morfológicas de macrófagos e células gigantes multinucleadas. Segundo os autores, os resultados demonstraram uma integração a longo prazo entre os implantes de titânio e os elementos celulares do osso medular e a possibilidade de utilização deste modelo experimental para avaliar as possíveis implicações desta interação no processo linfocitopoiético e hematopoiético.

Procurando avaliar a espessura da camada de óxido que forma-se sobre implantes de Ti cp após diferentes processos de limpeza, MACHBEEM et al. ${ }^{62}$ em 1993 utilizaram 12 discos de titânio que foram submetidos a 4 diferentes tipos de procedimentos de limpeza e desinfecção. O primeiro grupo de 3 discos foi submetido ao regime de limpeza padrão do sistema Brånemark, que compreende escovação com detergente, lavagem em água destilada, secagem com ar, limpeza ultrasônica em butanol por 10 minutos, 3 lavagens com álcool absoluto (a 
última com ultra-som) e secagem em um secador à vácuo. O segundo grupo (3 discos) foi submetido ao regime padrão do sistema Brånemark e posteriormente autoclavados. O terceiro grupo (3 discos) passou pelo tratamento padrão do sistema Brånemark e posteriormente tratamento por descarga de raios por radiofreqüência por 5 minutos. $O$ quarto grupo (3 discos) sofreu o mesmo tratamento do terceiro grupo, porém as amostras foram armazenadas em água tridestilada por 30 dias. Todas as amostras foram analisadas por espectroscopia eletrônica e nenhuma diferença significativa foi observada na camada de óxido formada nos 4 grupos.

Em 1993, ALBREKTSSON; ZARB $^{6}$ publicaram um artigo de revisão no qual vários aspectos da osseointegração foram abordados. O termo osseointegração foi definido como o processo pelo qual uma fixação rígida e clinicamente assintomática de um material aloplástico no osso seria obtida e mantida durante aplicação de carga funcional. Também foi destacada a importância da avaliação da resposta ultraestrutural em associação com a performance clínica nos estudos que avaliassem a osseointegração. Além das investigações ultraestruturais da interface osso/metal, os autores enfatizaram a observação de alguns parâmetros biológicos para que ocorra a osseointegração, a saber: a) biocompatibilidade do material, b) desenho do implante, c) superfície do implante, d) estado do sítio receptor, e) técnica cirúrgica e f) condições de carga oclusal. A observação de 105 implantes 
(NobelPharma) removidos por razões de desordem psicossomática ou post-mortem demonstrou, segundo os autores, que a osseointegração ideal atinge cerca de $80 \%$ ao nível do osso cortical, enquanto no osso medular esse valor encontra-se diminuído de $10 \%$ a $20 \%$. Apesar dos grandes avanços já obtidos, ressaltaram que muitas pesquisas deveriam ser realizadas para a obtenção de um total controle do processo de osseointegração nos mais diversos pacientes.

Em 1994, STEFLIK et al. ${ }^{77}$ avaliaram implantes de titânio rosqueáveis, implantes de óxido de alumina rosqueáveis e implantes de titânio em forma de lâmina através de microscopia eletrônica de transmissão e através de microscopia de transmissão de alta voltagem. Todas as observações foram obtidas de tecidos interfaciais não descalcificados de cães, nos quais foram inseridos implantes comercialmente disponíveis, na mandíbula. Dois implantes similares foram inseridos de ambos os lados da mandíbula, sendo que em 12 dos 18 cães utilizados, os implantes suportaram próteses fixas por 6 a 12 meses. Neste estudo os autores puderam observar a existência de uma matriz mineralizada em aposição direta sobre o mplante. Uma vez que o tecido mineralizado não recobriu toda a interface do implante, em outras regiões da interface foram observados tecidos não mineralizados. Nestas regiões foram observados osteoblastos em contato direto com a interface osso/implante. Este tecido incluía fibras colágenas, uma fina matriz interfibrilar, material semelhante a proteínas e osteoblastos. Os autores 
afirmaram que este estado reforçou o conceito de que a interface implante/tecido bucal seria uma zona dinâmica que consiste de atividades de remodelamento das células ósseas e matrizes extracelulares.

Neste mesmo ano, HELSINGEN; LYBERG $^{41}$ realizaram um estudo no qual foram comparadas a microestrutura superficial e os elementos componentes de 4 implantes odontológicos de titânio rosqueáveis de 4 diferentes fabricantes (Nobelpharma, Swede-Vet, 3i e Osseodent). Os implantes foram avaliados por microscopia eletrônica de varredura e análise radiográfica por energia dispersiva. Os 4 implantes não apresentaram diferenças qualitativas substanciais em relação à composição química. As observações ao nível ultraestrutural revelaram que os implantes Nobelpharma, 3i e Osseodent apresentaram topografia superficial bem semelhante, enquanto 0 implante Swede-Vent apresentou uma superfície mais irregular. Após a realização de um estudo clínico piloto, com acompanhamento clínico e radiográfico de 126 implantes inseridos e submetidos à carga funcional por períodos de 1 a 2 anos, os autores afirmaram não existir diferenças entre os 4 sistemas de implantes avaliados.

STEFLIK et al. ${ }^{76}$, em 1994, utilizando a mesma amostra de 72 implantes inseridos em 18 cães (mandíbula), investigaram a aposição e o comportamento do tecido ósseo ao redor de diferentes materiais e formatos de implantes. Os implantes avaliados foram do tipo rosqueável, 
de titânio ou cerâmica, inseridos em um estágio ou dois estágios. Avaliou-se também um sistema de implante em forma de lâmina, inserido em um estágio ou dois estágios. Os animais foram sacrificados em diferentes intervalos de tempo e os tecidos foram preparados para análise por morfometria computadorizada e avaliação morfológica. Neste estudo, o tecido de suporte apresentou-se extremamente dinâmico na interface osso/implante, tanto para o tecido mineralizado, quanto para $\circ$ tecido não mineralizado. Um ano após a aplicação de carga protética sobre os implantes, observou-se uma maior aposição óssea sobre os implantes de titânio, quando comparados aos implantes de cerâmica. Os autores ressaltaram que uma maior densidade óssea ocorreu após períodos de carga maiores, talvez devido a uma maior condensação lamelar do osso que suportava os implantes.

Em 1995, CARR et al. $^{24}$ publicaram um estudo no qual as diferentes forças para remoção por torque foram avaliadas em 3 tipos de implantes rosqueáveis $\left(\mathrm{Ti} \quad \mathrm{cp}, \quad \mathrm{Ti}_{6} \mathrm{Al}_{4} \mathrm{~V}\right.$ e revestido por hidroxiapatita). Implantes de tamanhos idênticos foram inseridos em regiões edêntulas da maxila e mandíbulas de 6 macacos, utilizando um protocolo cirúrgico padronizado (37 macacos em cada grupo). Após um período de tempo de 3 a 4 meses os implantes foram removidos em sentido anti-horário e os valores de torque obtidos foram avaliados estatisticamente em relação ao tipo de implante e à região inserida. Os valores obtidos para a hidroxiapatita foram maiores (média $=186,0 \mathrm{Ncm}$ ), enquanto para a liga 
$\mathrm{Tl}_{6} \mathrm{Al}_{4} \mathrm{~V}$ foram $78,6 \mathrm{Ncm}$ em média e para $\mathrm{Ti} \mathrm{cp}$ foram de $74,0 \mathrm{Ncm}$ em média. Não houve diferença significante entre o torque de remoção na mandíbula e na maxila, porém para cada grupo testado os valores obtidos na mandíbula foram sempre maiores que na maxila. Os autores concluíram que, dentro dos limites desse estudo, o torque recomendado para colocação de um intermediário seria de $35 \mathrm{Ncm}$ e forneceria uma margem de segurança para a maioria dos implantes com forma e material semelhantes aos utilizados neste estudo.

Neste mesmo ano, BROSH; PERSOVSKI; BINDERMAN ${ }^{16}$ avaliaram 4 parâmetros clínicos para caracterizarem as propriedades da interface osso-implante. Os parâmetros analisados foram o pico de força, o deslocamento vertical, a rigidez da interface e a energia tensional. Todos os parâmetros foram medidos no momento da inserção dos implantes e após 3 meses de cicatrização, utilizando testes de compressão dos implantes de titânio na mandíbula de 3 cães adultos. A comparação dos resultados cemonstrou que o pico de força, a rigidez da interface e a energia tensional aumentaram durante os 3 meses de cicatrização, enquanto o deslocamento vertical diminuiu. Os autores, baseados nas observações deste estudo, sugeriram que a rigidez da interface, a qual é considerada o principal fator de sucesso de um implante, aumentaria durante os 3 meses de cicatrização em cães, o que corresponde a 4 a 6 meses de cicatrização em mandíbulas humanas.

Um interessante estudo foi publicado em 1995 por 
GOHEEN et al. $^{36}$, comparando a utilização de dispositivos manuais e mecânicos para indução de torque nos componentes dos implantes osseointegrados. Esse estudo avaliou a habilidade de 5 cirurgiões e 11 protesistas em induzirem o torque desejado com dispositivos manuais, sendo que todos os profissionais tinham vasta experiência no uso dos componentes do sistema Brånemark. Foi solicitado a cada profissional a indução de forças de torque de 10, 20 e $32 \mathrm{Ncm}$. Os valores obtidos através de aparelhos demonstraram grande variação em relação aos valores solicitados aos profissionais. O torque gerado por aparelhos eletrônicos manteve-se dentro dos valores pré-determinados, o que demonstrou um melhor controle de torque quando da utilização de aparelhos eletrônicos pré-calibrados. Os autores sugerem o uso de aparelhos para a obtenção de valores de torque adequados ao procedimento utilizado.

CLOKIE; WARSHAWSKY ${ }^{25}$ desenvolveram em 1995 um modelo de estudo em tíbia de ratos para análise da osseointegração ao redor de implantes de titânio rosqueáveis. Implantes miniaturizados foram inseridos na região anterior da tíbia de 24 ratos adultos, sendo que 12 deles foram sacrificados 6 semanas após a inserção e 2 ratos foram sacrificados semanalmente durante 6 semanas subseqüentes. Quatro dias antes do sacrifício os animais receberam uma injeção intraperitoneal de ${ }^{3} \mathrm{H}$-prolina. As amostras foram fixadas e embebidas em resina, sendo que os implantes foram removidos e avaliados por microscopia óptica, 
eletrônica e radioautografia. As observações morfológicas demonstraram que a inserção do implante resultou em necrose e reabsorção óssea, seguida de crescimento ósseo a partir do osso antigo, preenchendo as roscas com canais vasculares e novo osso lamelar. A osseointegração completou-se em 6 semanas em todos os animais examinados. A microscopia eletrônica na interface osso/titânio demonstrou uma camada amorfa, uma camada granular elétron-densa ou uma camada de fibrilas colágenas não calcificadas. O novo osso radiomarcado foi depositado somente sobre o osso preexistente e estendeu-se em direção ao espaço disponível. Devido à inexistência de uma relação entre o implante e o novo osso, os autores sugeriram que o titânio é biocompatível, porém não necessariamente osteoindutor.

Em 1996, IVANOFF; SENNERBY; LEKHOLM ${ }^{43}$ avaliaram a força de remoção por torque e a resposta do tecido ósseo a implantes de titânio ancorados em uma ou duas corticais. Um total de 72 implantes de titânio rosqueáveis, com 10 ou $16 \mathrm{~mm}$ de extensão e $3,75 \mathrm{~mm}$ de diâmetro foi inserido nas tíbias esquerda e direita de 18 coelhos adultos da raça New Zeland. Os implantes foram ancorados em uma ou duas corticais, e a cicatrização ocorreu por 6 ou 12 semanas. O grau de osseointegração foi avaliado pelo torque de remoção utilizando-se um torquímetro. O cálculo histomorfométrico foi realizado em cortes histológicos com $10 \mu \mathrm{m}$ de espessura. Todos os implantes encontravamse clinicamente estáveis no final do experimento. $O$ torque de remoção 
foi duas vezes maior para os implantes com inserção bicortical 6 semanas após, e três vezes maior 12 semanas após a inserção. Os implantes de $16 \mathrm{~mm}$ de extensão apresentaram uma maior quantidade de tecido ósseo em contato com o implante após 6 e 12 semanas, quando comparados com os implantes de $10 \mathrm{~mm}$. De acordo com os autores, os resultados recomendam a obtenção de uma ancoragem bicortical nas situações clínicas.

Em estudo publicado em 1996, HANTHAMRONGWIT et al. ${ }^{40}$ cultivaram ceratinócitos humanos na superfície de esponjas de colágeno e utilizaram a microscopia confocal de varredura a laser (CLSM) para avaliar a microestrutura das esponjas, a morfologia das células e a sua distribuição através das esponjas. Os ceratinócitos penetraram nas esponjas a partir da incubação e atingiram um máximo de penetração 10 dias após, com uma profundidade de $120 \mu \mathrm{m}$. Apesar da presença dos ceratinócitos aumentar a distorção da estrutura das esponjas, alguns fatores inerentes ao meio de cultura também contribuíram para a ocorrência deste fenômeno. Os autores afirmaram que a microscopia confocal de varredura a laser é um poderoso recurso na avaliação das interações celulares com os bioimplantes, fornecendo informações qualitativas e quantitativas. A técnica utilizada fornece algumas vantagens sobre a microscopia de varredura convencional e sobre as técnicas histológicas por consumir um menor intervalo de tempo, não necessitar de extensivo preparo das amostras e permitir o 
seccionamento ótico seriado não invasivo de amostras intactas.

Em 1996, KONIJN et al. ${ }^{55}$ demonstraram que uma melhor visualização confocal do osso recém-formado é possível se este osso é marcado seqüencialmente in vivo com dois marcadores osteotrópicos (xylenol laranja e tetraciclina). A reconstrução das secções óticas confocais foram feitas através do uso do sistema de aplicação visual CONVEX (AVS). Os dados obtidos por imagem computadorizada fornecem ao pesquisador uma grande flexibilidade na apresentação dos resultados, levando à conclusão de que a microscopia confocal por varredura a laser em conjunto com o AVS é excelente para visualização do processo de remodelamento ósseo em três ou quatro dimensões, no qual a quarta dimensão é o tempo. Com esta abordagem a visualização do remodelamento ósseo tornou-se possível de uma forma que não é facilmente obtida por outras técnicas.

Em 1997, TAKESHITA et al. ${ }^{79}$ avaliaram a formação óssea ao redor de implantes revestidos por hidroxiapatita e titânio através de microscopia de luz, microscopia de varredura a laser, e processamento de imagens. Foram utilizados 65 ratos, divididos em 2 grupos: 60 utilizados em observação histológica e 5 utilizados para marcação óssea. A análise histométrica do percentual de contato ósseo revelou que os implantes de titânio apresentaram uma curva de crescimento contínuo, enquanto os implantes revestidos por hidroxiapatita apresentaram um rápido aumento no período inicial da cicatrização até 14 dias, com 96\% 
de contato ósseo ocorrido 84 dias após a inserção. A observação por microscopia de varredura confocal a laser revelou a presença de calceína no $14^{\circ}$ dia e somente pequena quantidade de alizarina no tecido ósseo no $28^{0}$ dia. Os dados sugeriram uma maior atividade óssea em torno de $14^{\circ}$ dia e que o percentual de contato ósseo foi maior nos implantes revestidos por hidroxiapatita.

Em estudo apresentado em 1997, IYAMA et al. ${ }^{44}$ Compararam a quantidade e a distribuição regional da formação óssea ao redor de implantes de hidroxiapatita em ratos normais (controle) e ratos com diabete induzida. Calceína, alizarina e tetraciclina foram injetadas nos animais no $7^{\circ}, 14^{\circ}$ e $21^{\circ}$ dias após a inserção dos implantes, sendo que o sacrifício foi realizado no $28^{\circ}$ dia. Os cortes histológicos foram preparados para leitura por microscopia confocal de varredura a laser. No grupo controle o tecido ósseo formou-se em um padrão laminado com três camadas de cores (calceína, alizarina e tetraciclina), mas no grupo experimental (diabéticos) não foi observada a presença da tetraciclina. Os autores demonstraram que no grupo controle foi observada uma intensa formação óssea a partir do endósseo e do periósteo, enquanto no grupo experimental esta formação óssea foi quase suprimida, principalmente ao redor do $21^{\circ}$ dia pós-inserção.

Em 1998, den BRABER et al. ${ }^{28}$ apresentaram um estudo no qual pequenas lâminas de titânio foram tratadas por ataque ácido para que apresentassem suas superfícies com microgranulações de 1,0 
$\mu \mathrm{m} ; 2,0 \mu \mathrm{m}, 5,0 \mu \mathrm{m}$ e 10,0 $\mu \mathrm{m}$. Após incubação em meio de cultura contendo fibroblastos por 3 dias as células foram observadas por microscopia de varredura, por microscopia de transmissão e por microscopia confocal a laser. Os autores observaram uma orientação paralela das fibras sobre as granulações de 1,0 $\mu \mathrm{m}$ e 2,0 $\mu \mathrm{m}$, enquanto muitos pontos de adesão puderam ser observados sobre as granulações de $5,0 \mu \mathrm{m}$ e $10,0 \mu \mathrm{m}$. Somente sobre a granulação de 10,0 $\mu \mathrm{m}$ puderam ser observados pontos de adesão no fundo dos sulcos. Os autores relataram que a orientação dos fibroblastos não estaria relacionada com as propriedades específicas do material, porém quando comparado com superfícies de silicone o titânio apresentou uma proliferação de fibroblastos muito maior. 


\section{3 - PROPOSIÇÃO}




\section{3 - PROPOSIÇÃO}

Este trabalho metodológico se propõe a avaliar o sistema de implante NAPIO no tocante:

a) à correlação entre os valores obtidos no torque da força de remoção dos implantes e eventos da cicatrização em relação ao tempo de cicatrização;

b) à presença de sítios de calcificação e crescimento ósseo em relação à superfície dos implantes através de microscopia confocal de varredura a laser;

c) a possível diferença da atividade óssea em relação às regiões cortical e medular, através de análise em microscópio confocal a laser.

d) à viabilidade da análise por microscopia confocal á laser dos eventos da osseointegração. 
4 - MATERIAL E MÉTODOS 


\section{4 - MATERIAL E MÉTODOS}

$\mathrm{Na}$ confecção deste estudo foram utilizados 7 coelhos da raça New Zeland (5 machos e 2 fêmeas) com peso variável entre 2,9 e 3,8 kg. Cada animal sofreu a inserção de 2 implantes na tíbia esquerda. Um dos implantes foi utilizado para avaliação histológica e o outro foi utilizado para avaliação da força de remoção por torque. Todos os implantes foram produzidos pelo NAPIO (Núcleo de Apoio à Pesquisa em Implantes Odontológicos - Faculdade de Odontologia de Bauru- USP), usinados em titânio grau I com composição química controlada. Os implantes NAPIO utilizados apresentavam um comprimento de $10 \mathrm{~mm}$, diâmetro de $3,75 \mathrm{~mm}$ e foram tratados previamente conforme descrito a seguir:

1. lavagem com tricloroetileno por 10 minutos em ultra-som;

2. lavagem com álcool absoluto por 10 minutos em ultra-som;

3. remoção das rebarbas da usinagem (com lupa de $40 \mathrm{x}$ aumento);

5. jateamento com esferas de vidro;

6. lavagem com tricloroetileno por 10 minutos em ultra-som;

7. lavagem com álcool absoluto por 10 minutos em ultra-som;

8. lavagem com álcool absoluto por 10 minutos em ultra-som;

9. jateamento com óxido de alumínio;

10. lavagem com tricloroetileno por 10 minutos em ultra-som;

11. lavagem com álcool absoluto por 10 minutos em ultra-som;

12. inserção em ácido sulfúrico 10\% por 10 minutos em ultra-som;

13. três lavagens com água deionizada em bidestilada; 
14. lavagem com tricloroetileno por 10 minutos em ultra-som;

15. lavagem com álcool absoluto por 10 minutos em ultra-som;

16. lavagem com álcool absoluto por 10 minutos em ultra-som;

17. secagem ao ar;

18. passivação em estufa a $180^{\circ} \mathrm{C}$ por 30 minutos;

19. colocação dos implantes em ampolas de vidro contendo álcool etílico a $10 \%$;

20. esterilização em autoclave a $121^{\circ} \mathrm{C}$ por 20 minutos.

Os animais foram sedados utilizando-se inicialmente um relaxante muscular (Rompum; Bayer) via intramuscular $(0,28 \mathrm{ml} / \mathrm{kg}$ de peso corporal). Após 5 minutos, seguiu-se com a aplicação do anestésico (Ketalar; Park-Davis) também por via intramuscular $(0,39 \mathrm{ml} / \mathrm{kg}$ de peso corporal) (Figura 1).

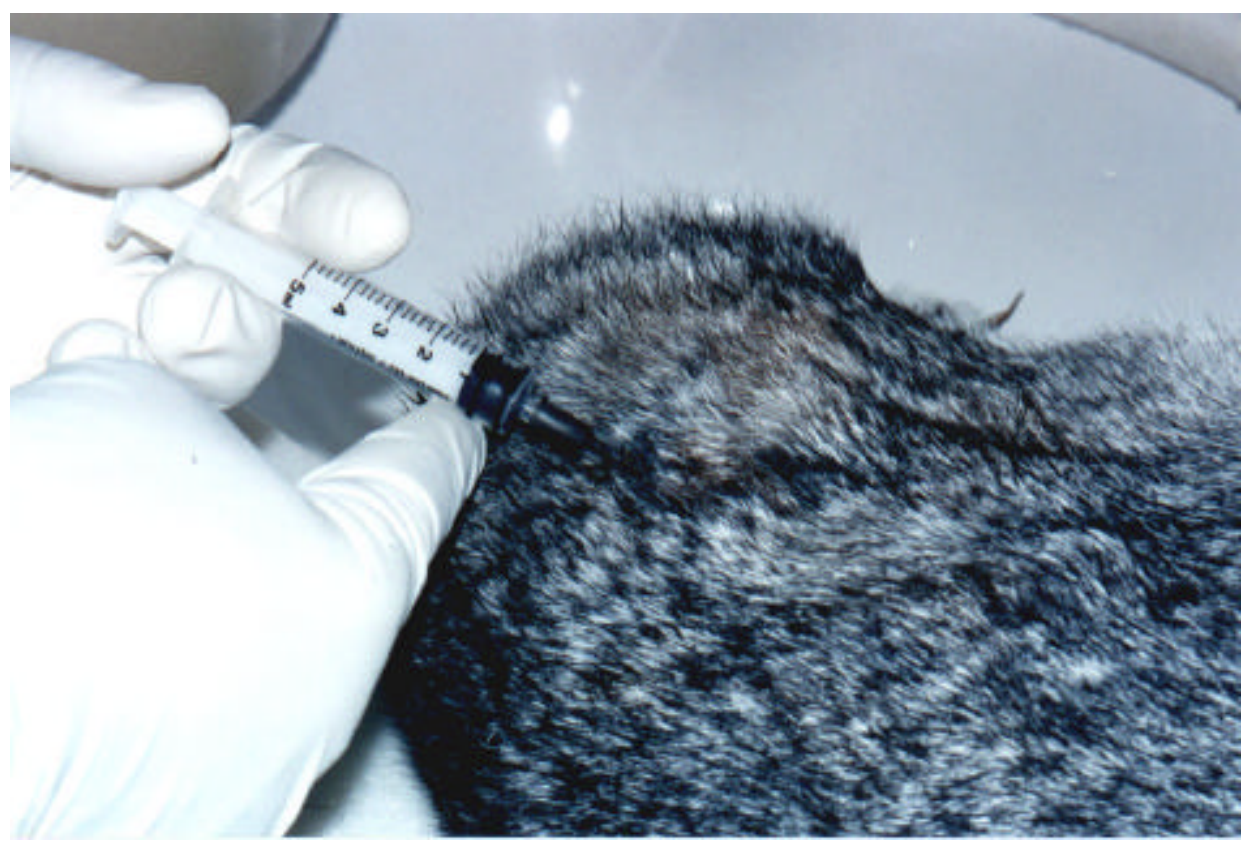

FIGURA 1 - Aplicação da solução anestésica via I.M. para sedação do animal 
A seguir realizou-se a tricotomia da região escolhida da tíbia esquerda do animal. A antissepsia da área foi executada com um degermante à base de polivinilpirrolidona, seguido de álcool iodado. A área a ser incisada foi infiltrada com lidocaína a $2 \%$ para que se conseguisse uma hemostasia local mais efetiva durante 0 procedimento cirúrgico. Foi realizada uma incisão com lâmina de bisturi $n^{\circ} 15$ de aproximadamente $8 \mathrm{~cm}$, em sentido longitudinal à tíbia, ultrapassando a pele, o tecido muscular e o periósteo para alcançar o tecido ósseo (Figura 2).

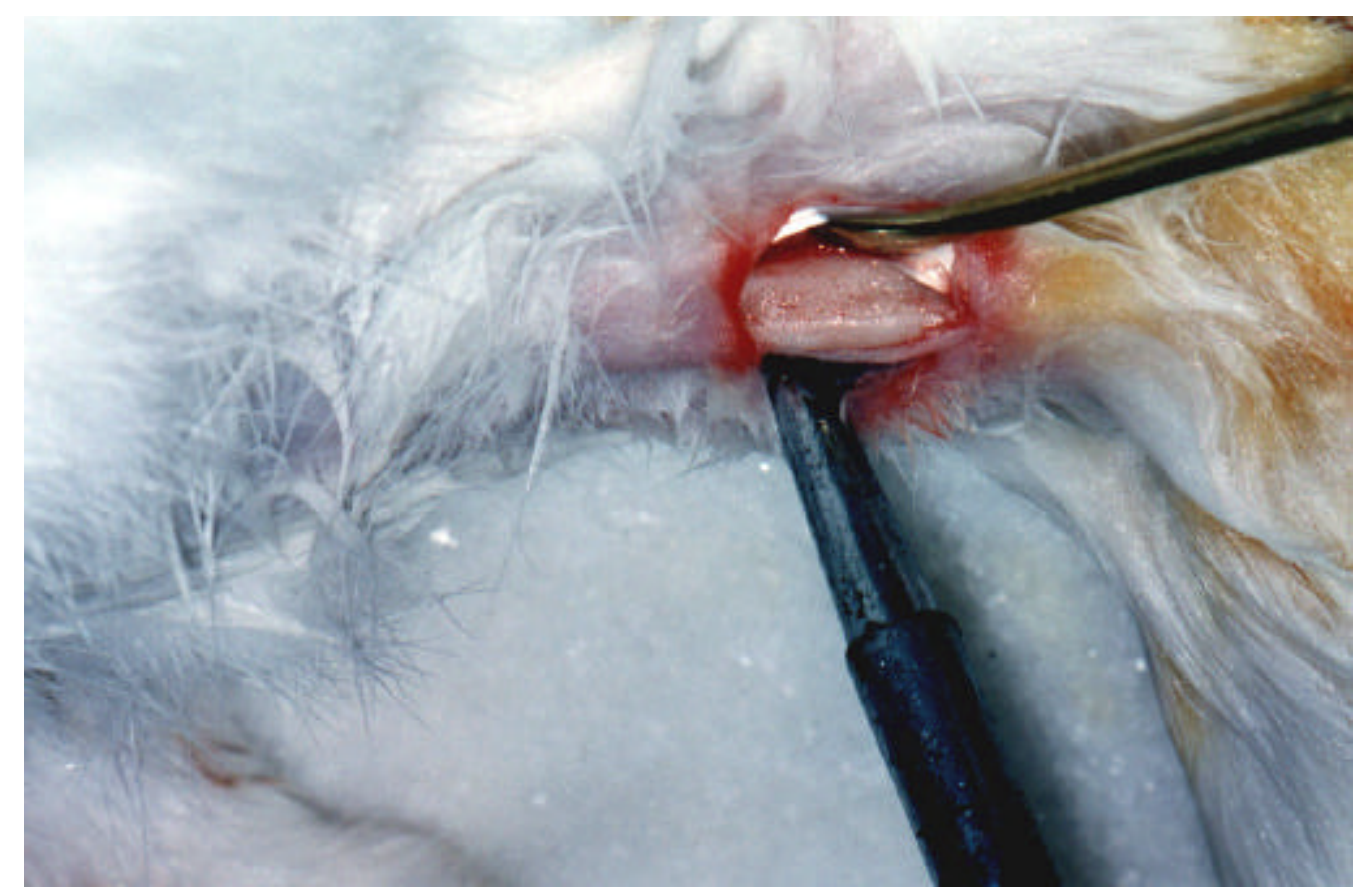

FIGURA 2 - Incisão para exposição da tíbia 
Neste leito de tecido ósseo foram realizadas duas perfurações para instalação de dois implantes. Estas perfurações foram realizadas por uma broca esférica seguida de uma broca cilíndrica de 3

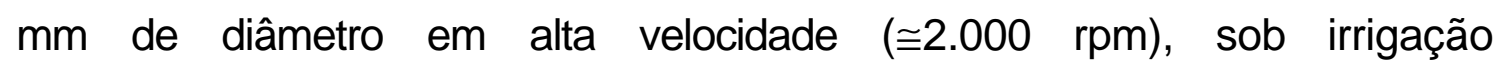
abundante com soro fisiológico, como preconiza a técnica cirúrgica (Figuras 3, 4 e 5).

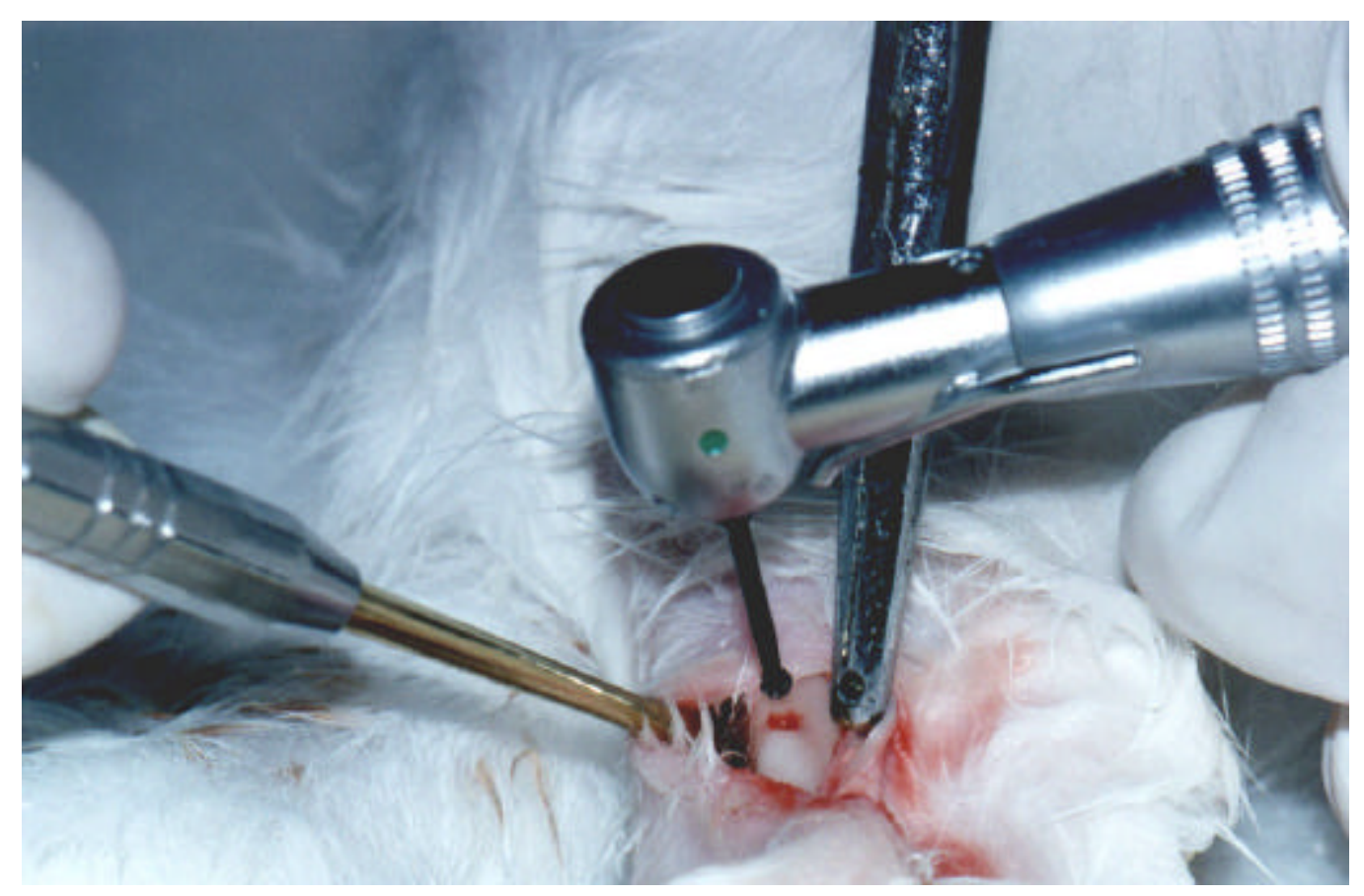

FIGURA 3 - Perfuração óssea com broca esférica 


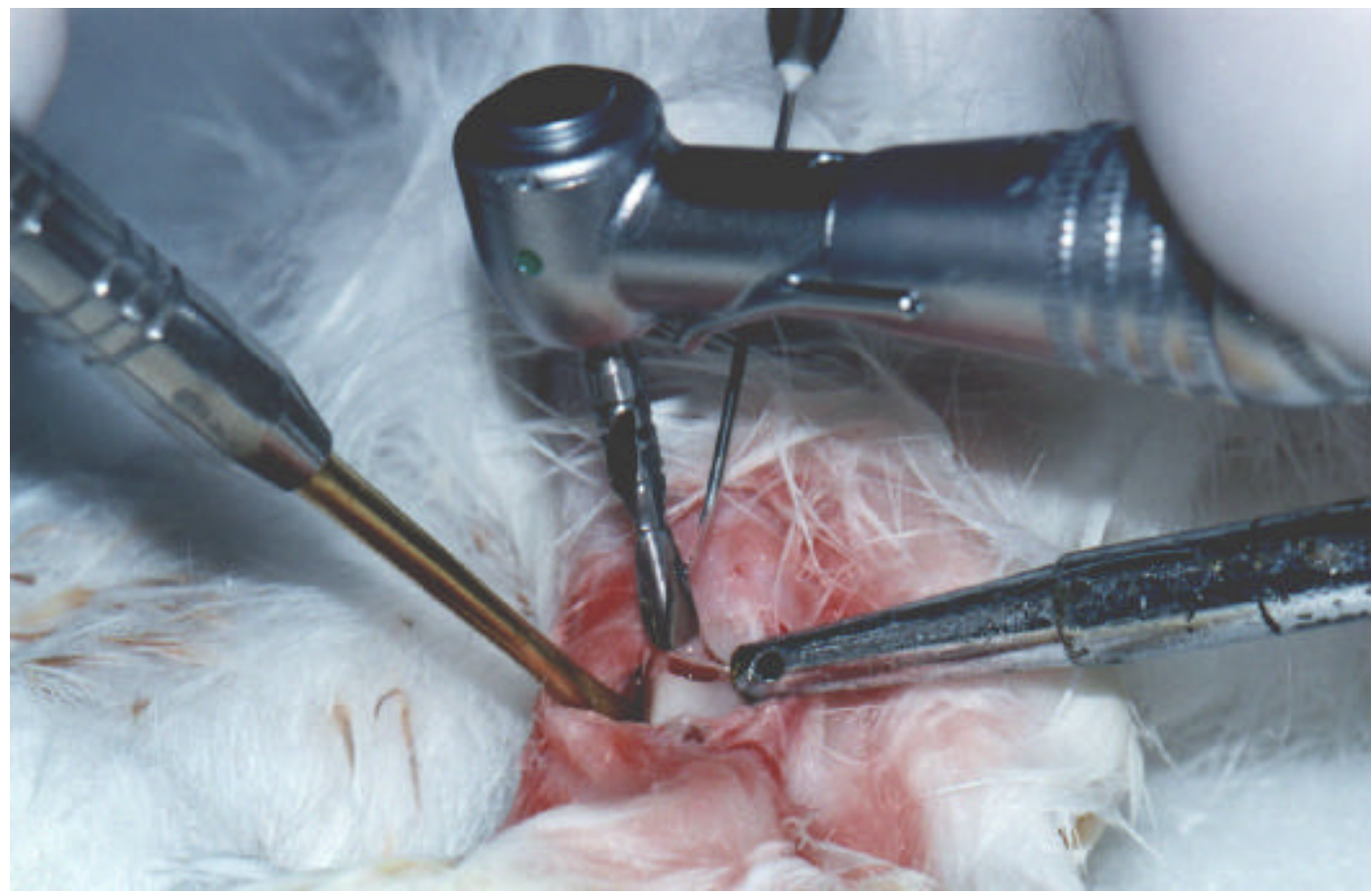

FIGURA 4 - Perfuração (alargamento) com broca cilíndrica de $3 \mathrm{~mm}$ de diâmetro

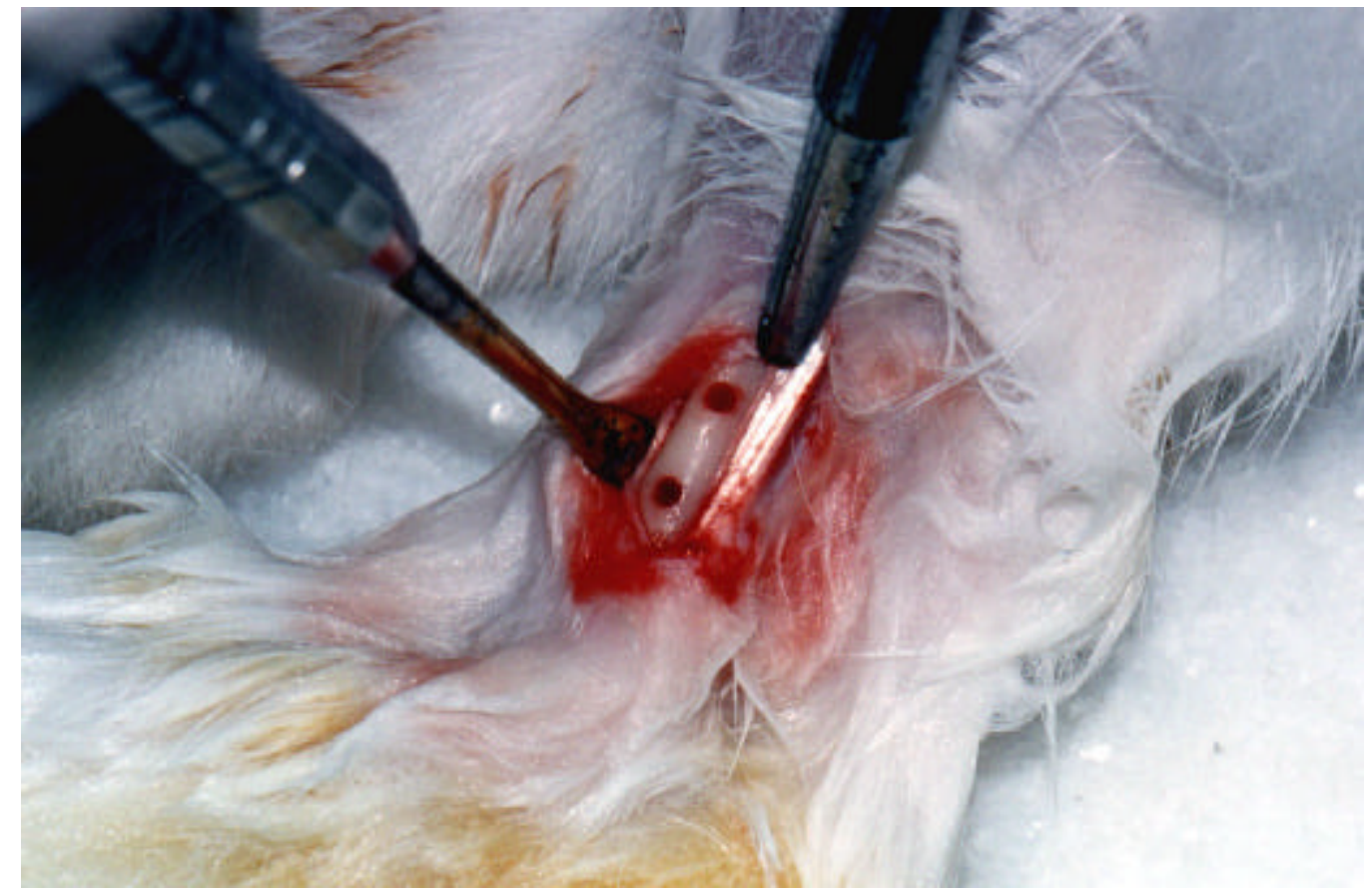

FIGURA 5 - Visão direta das duas perfurações realizadas 
Os implantes para avaliação histológica foram inseridos utilizando-se o motor do sistema NAPIO, e os implantes da cabeça quadrada para avaliação do torque foram inseridos utilizando-se a chave do sistema NAPIO. A velocidade de inserção foi de $20 \mathrm{rpm}$ (Figuras 6, 7 e 8).

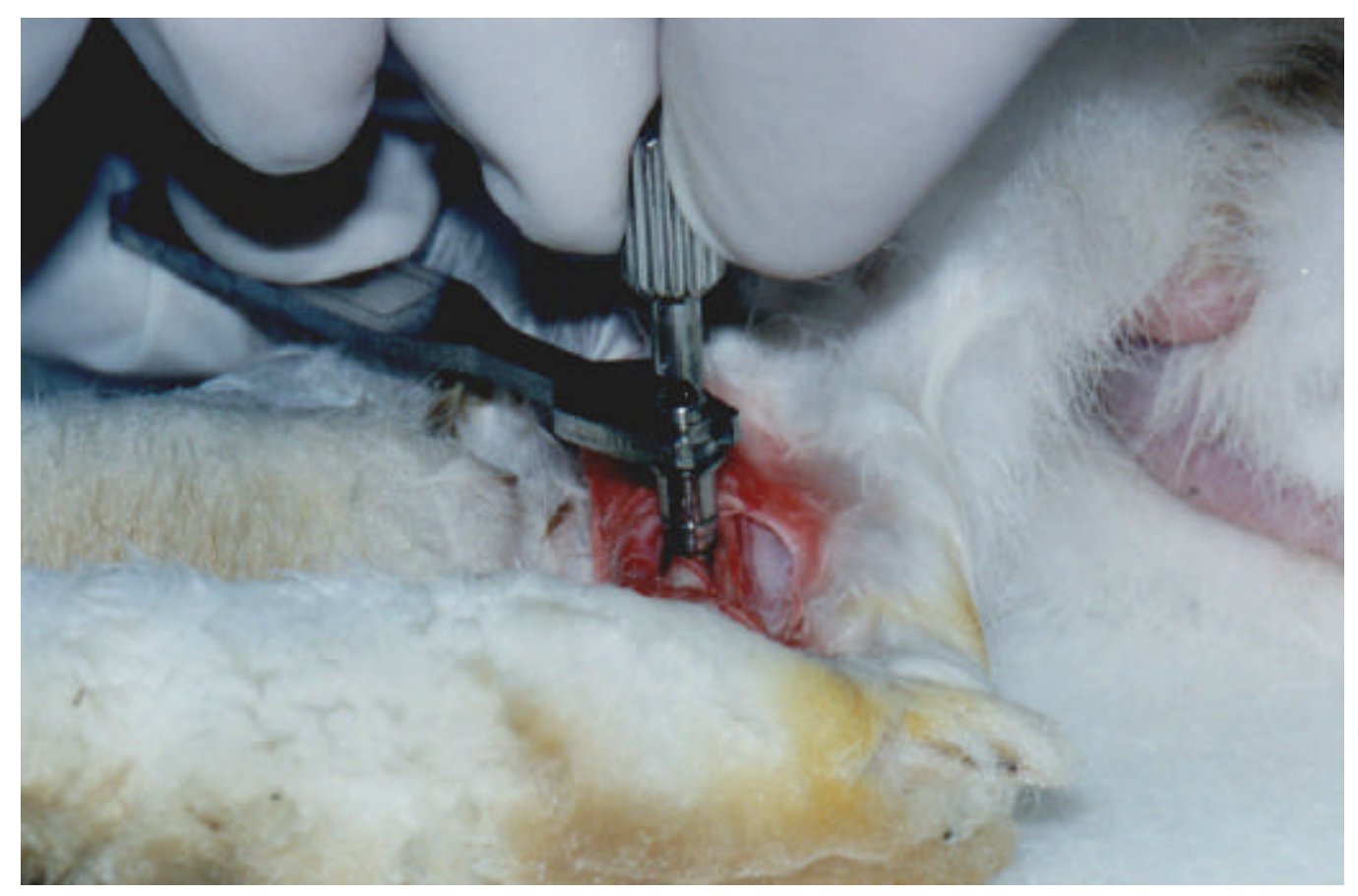

FIGURA 6 - Desmontagem do porta-implante após a sua inserção utilizando o motor do sistema NAPIO 


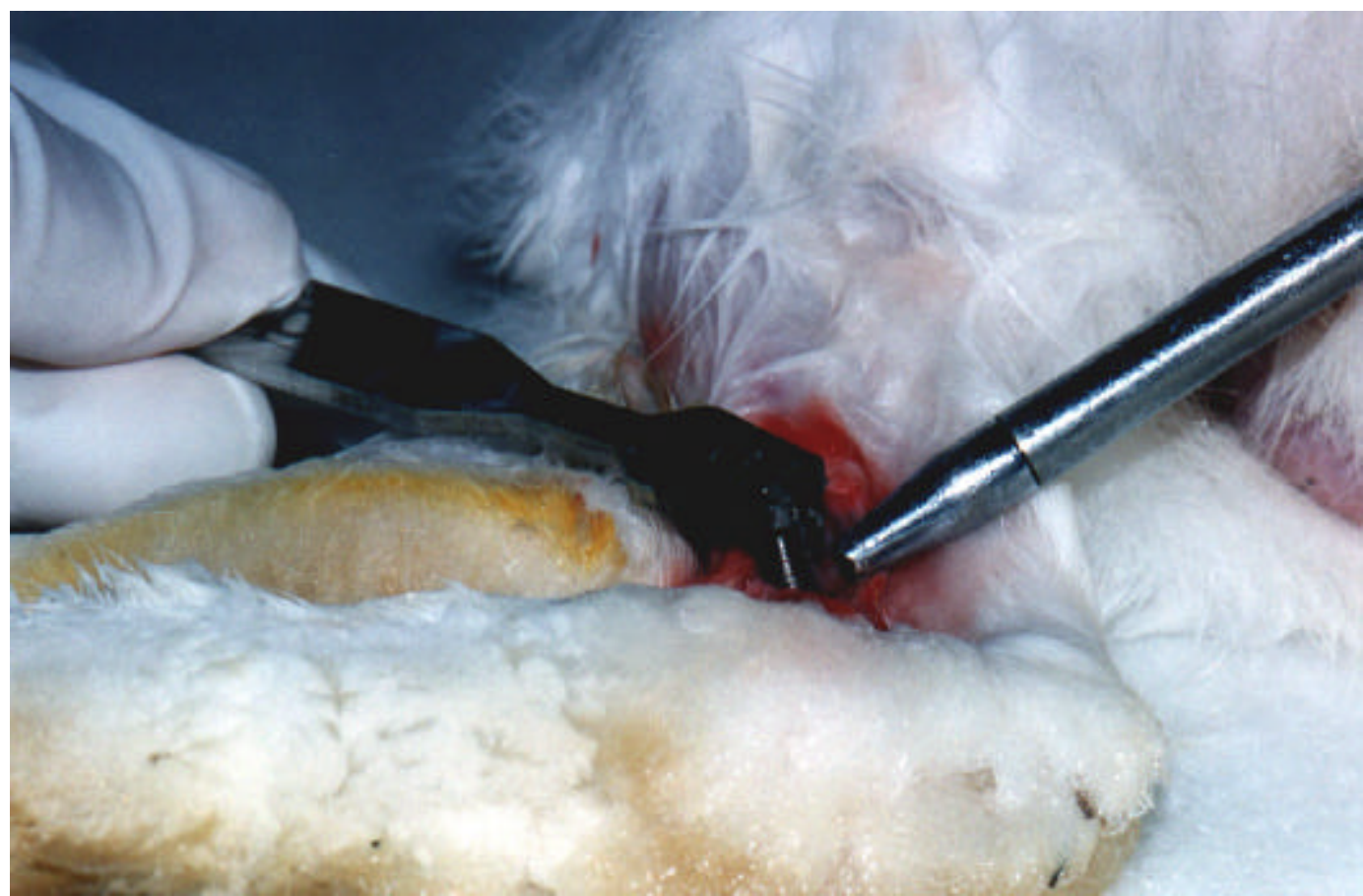

FIGURA 7 - Inserção do implante de cabeça quadrada para avaliação posterior com o torquímetro

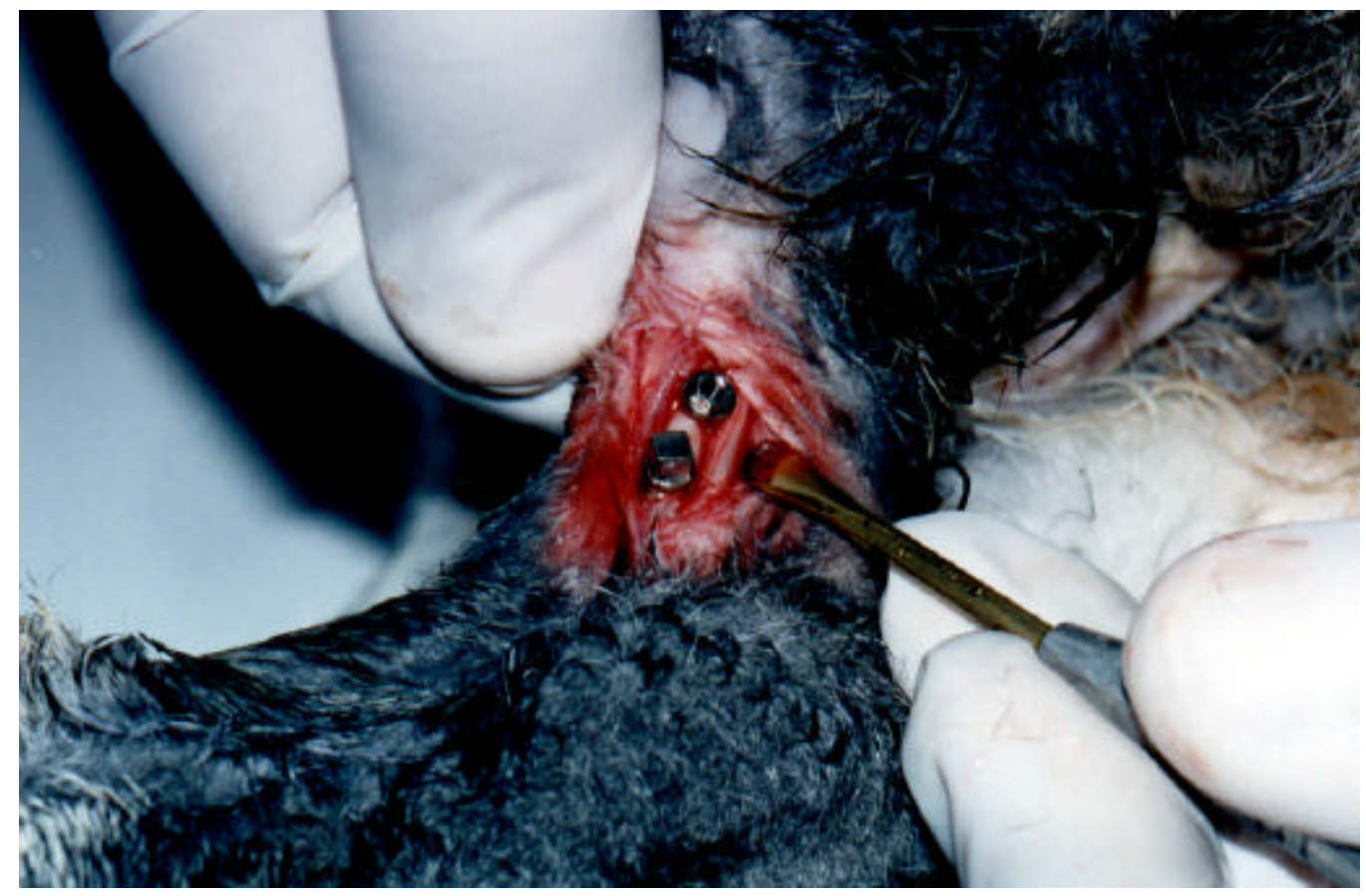

FIGURA 8 - Visão direta dos implantes já inseridos 
O implante de cabeça quadrada foi utilizado para teste de remoção por torque, enquanto que o outro foi utilizado para controle histológico. Após a conclusão da inserção, o retalho foi readaptado ao leito e suturado com fio de seda preta 40 agulhado Ethicon (Johnson \& Johnson) (Figura 9). Tomou-se um cuidado especial para que houvesse no mínimo $4 \mathrm{~mm}$ de tecido ósseo entre os implantes colocados.

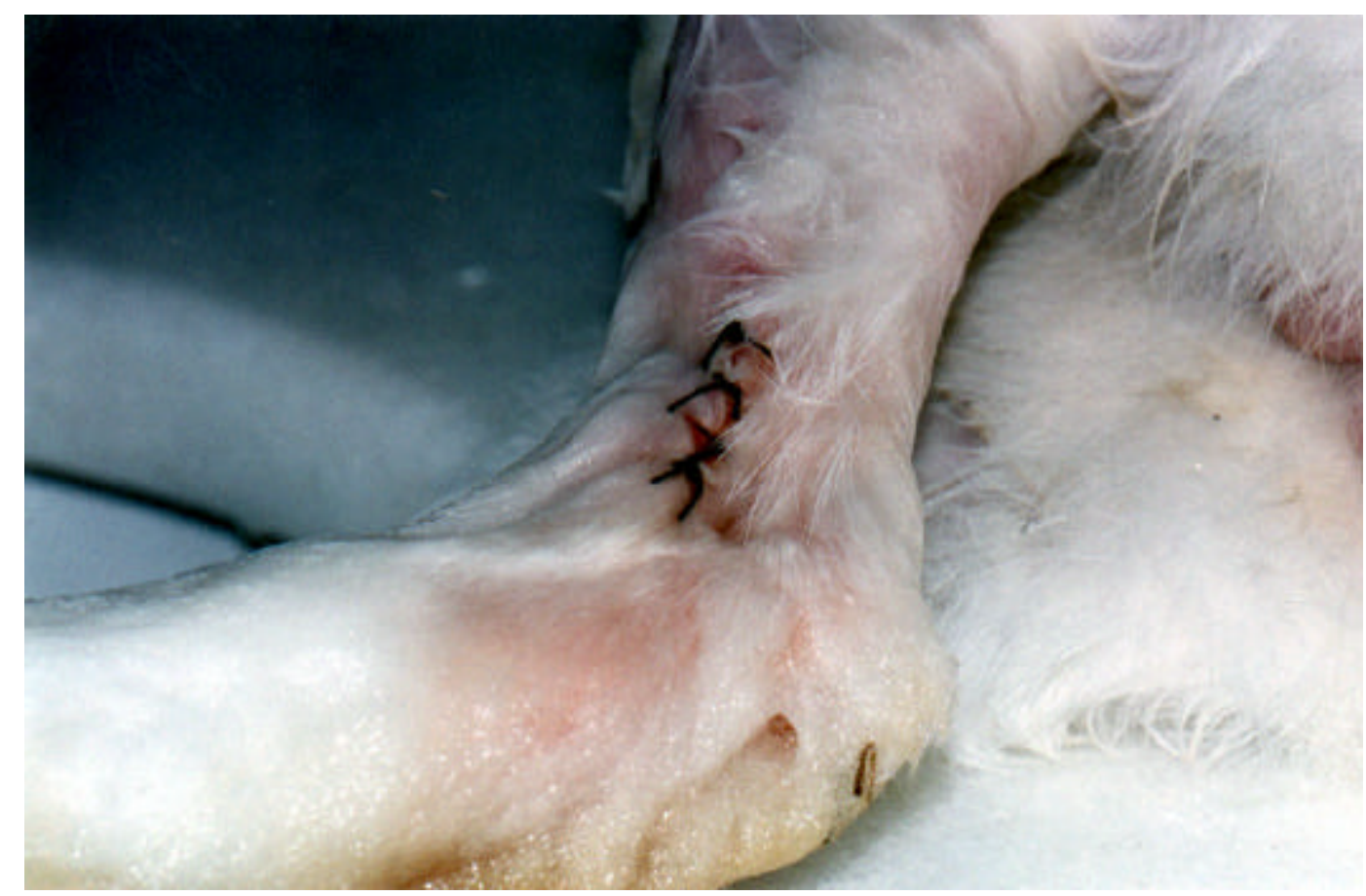

FIGURA 9 - Incisão suturada 
Os animais foram numerados de 1 a 7 no dia zero. Imediatamente após a inserção, os implantes foram radiografados para verificação da adaptação ao tecido ósseo (Figura 10) e em seqüência os animais receberam a primeira dose do primeiro marcador ósseo (Tetraciclina $25 \mathrm{mg} / \mathrm{kg}$ ), excetuando-se o animal 7. Uma semana após a inserção, os animais $1,2,3,4,5$ e 6 receberam a segunda dose do primeiro marcador (Tetraciclina $25 \mathrm{mg} / \mathrm{kg}$ ) via intramuscular.

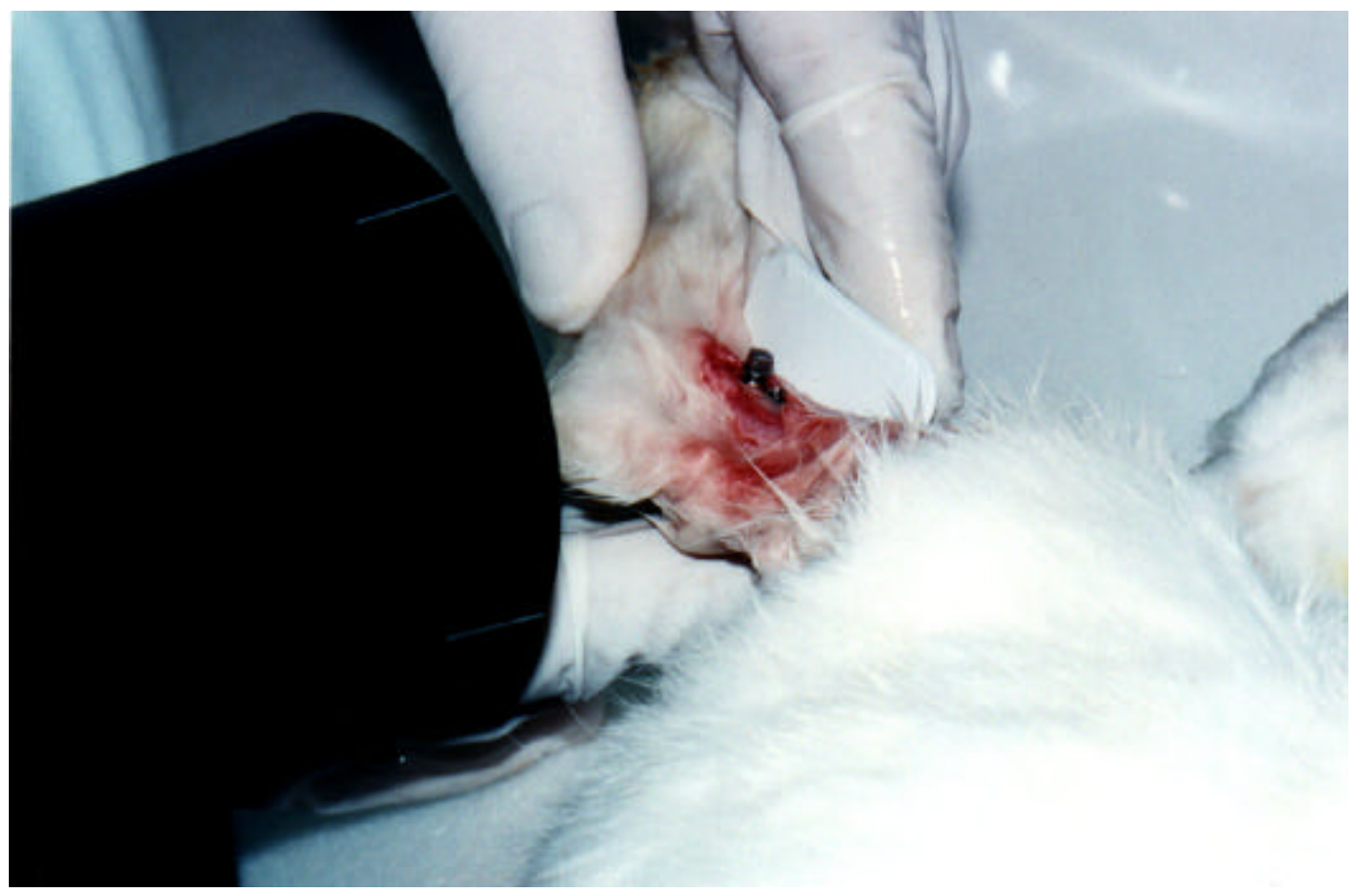

FIGURA 10 - Tomada radiográfica logo após a inserção dos implantes 
Quinze dias após inserção, os animais 3, 4, 5 e 6 receberam a primeira dose do segundo marcador ósseo (Alizarina $30 \mathrm{mg} / \mathrm{kg}$ ) via intramuscular, enquanto que os animais 1 e 2 foram sacrificados. Os animais foram sacrificados utilizando-se uma dose excessiva de anestésico (Ketalar; Parke-Davis) de $2 \mathrm{ml} / \mathrm{kg}$ de peso corporal. Em seguida realizou-se uma incisão, através da pele e da camada muscular, para que os implantes pudessem ser encontrados. Em alguns casos, realizou-se uma pequena osteotomia para exposição da cabeça do implante. O implante de cabeça quadrada foi conectado a um torquímetro digital ATG 1.500 Nm (MecmesinInglaterra) e o valor obtido foi registrado. Em seqüência a pata do animal foi amputada sendo fixada em formalina a $4 \%$ e a peça foi processada para análise histológica. Vinte um dias após a inserção dos implantes, os animais 3, 4, 5 e 6 receberam a segunda dose do segundo marcador ósseo (Alizarina $30 \mathrm{mg} / \mathrm{kg}$ ). Decorridos 45 dias após a inserção os animais 3 e 4 foram sacrificados seguindo a metodologia previamente descrita enquanto os animais 5 e 6 receberam a primeira dose do terceiro marcador ósseo (Calceína $20 \mathrm{mg} / \mathrm{kg}$ ) via intramuscular. Após 52 dias os animais 5 e 6 receberam a segunda dose do terceiro marcador ósseo (Calceína 20 mg/kg). Noventa dias após a inserção os animais 5 e 6 foram sacrificados para a obtenção e registro dos dados. $\mathrm{O}$ animal 7 foi sacrificado 180 dias após a inserção e obteve-se o valor da força de força de remoção por torque. 0 implante para avaliação histológica também foi processado, apesar do modelo experimental objetivar a não utilização dos marcadores ósseos neste 
último animal. A única ocorrência não programada durante a fase experimental foi a fratura da tíbia na região do implante que seria utilizado para avaliação histológica no animal 2.

\section{PROCESSAMENTO LABORATORIAL}

\section{Técnica histológica para tecido mineralizado}

A técnica histológica utilizada para avaliação da estrutura osso/implante deve preservar da melhor forma possível a mesma relação existente entre as estruturas in vivo. Na implantodontia, grande avanços ocorreram em relação às técnicas de processamento e avaliação histológica.

A técnica de corte por desgaste é um método usado para obter secções finas (menores que $10 \mu \mathrm{m}$ ) para exame histológico de espécimes que não podem ser processados por técnicas convencionais como, por exemplo, a inclusão em parafina. Para a preparação de cortes finos para diagnóstico histológico por transiluminação, são necessárias máquinas, acessónios e suplementos cuja descrição e uso serão feitos a seguir:

\section{1 - Máquinas}

1.1 - Sistema EXAKT de corte por desgaste

1.2 - Sistema EXAKT de micro-desgaste 


\section{2 - Acessórios}

2.1 - Sistema EXAKT de adesão pelo vácuo para preparação de blocos paralelos

2.2 - Sistema EXAKT de precisão para adesão de lâminas

2.3 - Unidade de polimerização EXAKT-KULZER

2.4 - Micrômetro com mostrador digital

2.5 - Sistema EXAKT para infiltração

2.6 - Navalha reta para certificação do paralelismo do bloco

\section{3 - Suplementos}

\section{1 - KULZER-EXAKT}

. meio de inclusão(Technovit 72.00 VLC)

. Technovit 4.000

. Technovit de adesão

. Fixação adesiva (Technovit 72.30 VLC)

. Moldes para inclusão (transparentes)

. lâminas plásticas

. lixas de diferentes granulações

\section{2 - Outros}

- glicolmetacrilato

. meio de montagem (Technovit 72.00 VLC) e lamínulas

. benzina ou acetona

Após a fixação, o bloco removido da pata do animal foi 
preparado até se obter uma porção tecidual de 2 a $4 \mathrm{~mm}$ de espessura, que pôde ser fixada com boa preservação. A superfície de corte foi colocada paralela ao eixo longitudinal do implante.

O espécime foi então lavado em água corrente por 2 horas para eliminação do fixador. Passou-se à fase da desidratação, obtida através de soluções de álcool etílico gradualmente da concentração de $60^{\circ}$ GL até o álcool absoluto, com tempo de 3 dias para cada concentração sob agitação constante.

A etapa seguinte foi a infiltração plástica, realizada com uma seqüência de concentrações de glicometacrilato, terminando com 2 infiltrações de glicometacrilato puro. Cada infiltração durou 3 dias, sob agitação constante.

A seguir, os espécimes infiltrados foram colocados em moldes apropriados para inclusão e foram realizadas a polimerização inicial com luz amarela e a polimerização final com luz azul, por aproximadamente 4 horas pelo sistema de adesão EXAKT pelo vácuo (prensa), a peça foi levada para um corte preliminar no sistema de corte EXAKT. Em seguida, após a verificação do paralelismo, a superfície do espécime foi submetida ao nivelamento e alisamento superficial por ação do sistema EXAKT de microdesgaste.

Realizou-se então a adesão de uma segunda lâmina (lâmina final) e o conjunto sofreu um novo desgaste no sistema EXAKT de microdesgaste até obter uma espessura entre 80 e $100 \mu \mathrm{m}$. 
As lâminas foram então lavadas em água corrente por 10 minutos e secadas com papel absorvente. Recobriu-se as lâminas com uma lamínula, sendo esta aderida pela resina Technovit 7200 VLC e polimerizada por luz durante 5 minutos.

Utilizou-se para a leitura das lâminas um microscópio Leica TCS NT, acoplado a uma fonte de emissão de um feixe de laser de íons $\mathrm{Ar} / \mathrm{Kr}$, com objetivas Leitz PL APO $40 \times$ para imersão em óleo, associado a dois monitores Mitsubish Diamond PRO 91 TXM.

Para cada lâmina, foram avaliadas três regiões contadas a partir da primeira rosca imediatamente subjacente à cortical superior, sendo uma nesta região e duas mais inferiormente, na região subcortical e medular. Para cada área avaliada, realizou-se secção óptica seriada através de método de varredura confocal a laser multicolorido. A imagem foi adquirida em dois canais separados destinados à detecção do $1^{0}$ sinal (fluorescência vermelha - alizarina; reflexão-tetraciclina) e do $2^{\circ}$ sinal (fluorescência verde-calceína; tetraciclina) denominados, respectivamente, de canais 1 e 2 . O seccionamento óptico permite a varredura das amostras no eixo $z$ e posterior reconstrução tri-dimensional da imagem obtida. O canal I registrou a fluorescência vermelha emitida das amostras pela Alizarina (dias 15 e 21), enquanto o canal II registrou a fluorescência verde emitida pela Calceína (dias 45 e 52). As imagens obtidas pelos canais I e II foram então fundidas para que fosse registrada a dupla fluorescência vermelha e verde gerada pelo computador. Por ter 
sido a Calceína o último marcador no tecido ósseo utilizado, a fluorescência verde apareceu no tecido ósseo mais próximo à superfície do implante, enquanto a fluorescência vermelha (Alizarina) foi observada no tecido ósseo mais distante da superfície do implante. Todos os tecidos não marcados, como por exemplo o osso preexistente ou o osso formado em períodos nos quais não foram usados marcadores fluorescentes, foram observados em tonalidades escuras. Utilizando os recursos oferecidos pela microscopia confocal foi possível realizar a sobreposição de todos os cortes óticos formando uma imagem tridimensional da interface osso/implante (planos $x, y$ e $z$ ). Uma imagem ainda mais interessante pode ser obtida quando foram fundidas (sobrepostas) as imagens processadas para a Alizarina e a Calceína. Como os marcadores do crescimento ósseo foram administrados em diferentes intervalos de tempo, está implícito que a mesma unidade óssea foi observada em uma mesma imagem em diferentes estágios do seu desenvolvimento. Torna-se então o tempo um fator extra adicionado à imagem que passa a ser observada em 4 dimensões (4D). Para análise microscópica os filtros utilizados foram:

. método FITC/TRITC para visualização da alizarina e . método reflexão/TRITC para visualização da tetraciclina. 
Os comprimentos de onda de excitação e emissão dos fluorocronos foram:

\begin{tabular}{|l|c|c|c|}
\cline { 2 - 4 } \multicolumn{1}{c|}{} & EXCIT. & EMISS. & COR \\
\hline ALIZARINA & $580 \mathrm{~nm}$ & $600 \mathrm{~nm}$ & Vermelho \\
\hline CALCEÍNA & $495 \mathrm{~nm}$ & $520 \mathrm{~nm}$ & Verde \\
\hline TETRACICLINA & - & - & natural \\
\hline
\end{tabular}

Todas as imagens obtidas foram armazenadas no computador para que os resultados e a análise numérica da formação óssea ao redor do implante pudessem ser obtidos.

O corte obtido de cada espécime foi muito espesso, para permitir-se a análise em profundidade de cada região, o que permitiu somente uma ou duas lâminas de cada implante.

As análises feitas foram por método descritivo, perfil da fluorescência e histograma de concentração de picos de emissão. $O$ processamento de análise no microscópio foi extremamente longo, na magnitude de muitas horas por lâmina, o que poderia danificar as amostras pela concetração de energia provocada pela incidência de argôniokriptônio,mas, apesar de não terem sido usados agentes "anti-fading" controlou-se os eventuais danos com uso de "pinholes" bastante diminutos.

As caracteríticas de tomada de cada imagem estão expressas no corpo da figuras.

A análise descritiva. 


\section{5 - RESULTADOS}




\section{5 - RESULTADOS}

A seguir serão apresentados os resultados obtidos a partir da coleta dos dados.

Primeiramente podemos observar os valores obtidos para a força de torque de remoção dos implantes, de acordo com os diferentes intervalos de tempo, após a inserção dos mesmos.

Animal $1-7,49 \mathrm{Ncm}$ (15 dias após a inserção) Animal 2-7,12 Ncm (15 dias após a inserção)

$\Rightarrow$ Média=7,30 Ncm

Animal 3-35,4 Ncm (45 dias após a inserção) Animal $4-31,1 \mathrm{Ncm}$ (45 dias após a inserção)

$\Rightarrow$ Média=35,25 Ncm

Animal $5-58,1 \mathrm{Ncm}$ (90 dias após a inserção) Animal $6-47,2 \mathrm{Ncm}$ (90 dias após a inserção)

$\Rightarrow$ Média $=52,65 \mathrm{Ncm}$

Animal $7-79,7$ Ncm (180 dias após a inserção)

Todos os valores previamente citados foram obtidos através de um torquímetro digital ATG 1.500 (Mecmesin-England) no momento do sacrifício dos animais, através da remoção dos implantes de cabeça quadrada, indicados para esta avaliação.

Os implantes para avaliação histológica permaneceram em posição e foram processados como já descrito no capítulo de Material e Métodos. 
Análise em microscópio confocal a laser multicolorido (CLSM)

Para cada lâmina, foram avaliadas as roscas correspondentes às regiões cortical, sub-cortical e medular com objetivas de imersão com aumentos de 20 e 40 vezes.

A descrição dos dados obtidos será descrita a seguir, de acordo com cada lâmina avaliada. 


\section{Lâmina 1 (observações gerais):}

Observou-se a presença de razoável volume ósseo nas regiões de cortical superior e inferior, diminuindo na região medular. Nas roscas correspondentes à cortical superior (roscas 1 e 2), notou-se a presença de TTC, especialmente nas áreas correspondentes à luz dos canais vasculares intra-ósseos (Figura 11). Em maior aumento, observa-se apenas áreas avermelhadas, representando regiões de marcação inespecífica. As áreas coradas em verde (Figura 12) representam dados obtidos do canal 1 (reflexão). Nas roscas 3 e 4, as mesmas características são visualizadas, porém com espaços medulares mais amplos (Figura 13). Em maior aumento, observa-se 3 áreas concêntricas marcadas com TTC (Figura 14). $\mathrm{Na}$ rosca 5 , correspondente à região de medular, pouco volume ósseo pode ser observado. $\mathrm{Na}$ rosca 6 , correspondente à região de cortical inferior, algumas áreas foram marcadas com TTC (Figura 15). Em maior aumento, especialmente correspondente à região medular, não se observa a presença do marcador (Figura 16). As áreas em vermelho parecem ser representativas de regiões marcadas inespecificamente. 


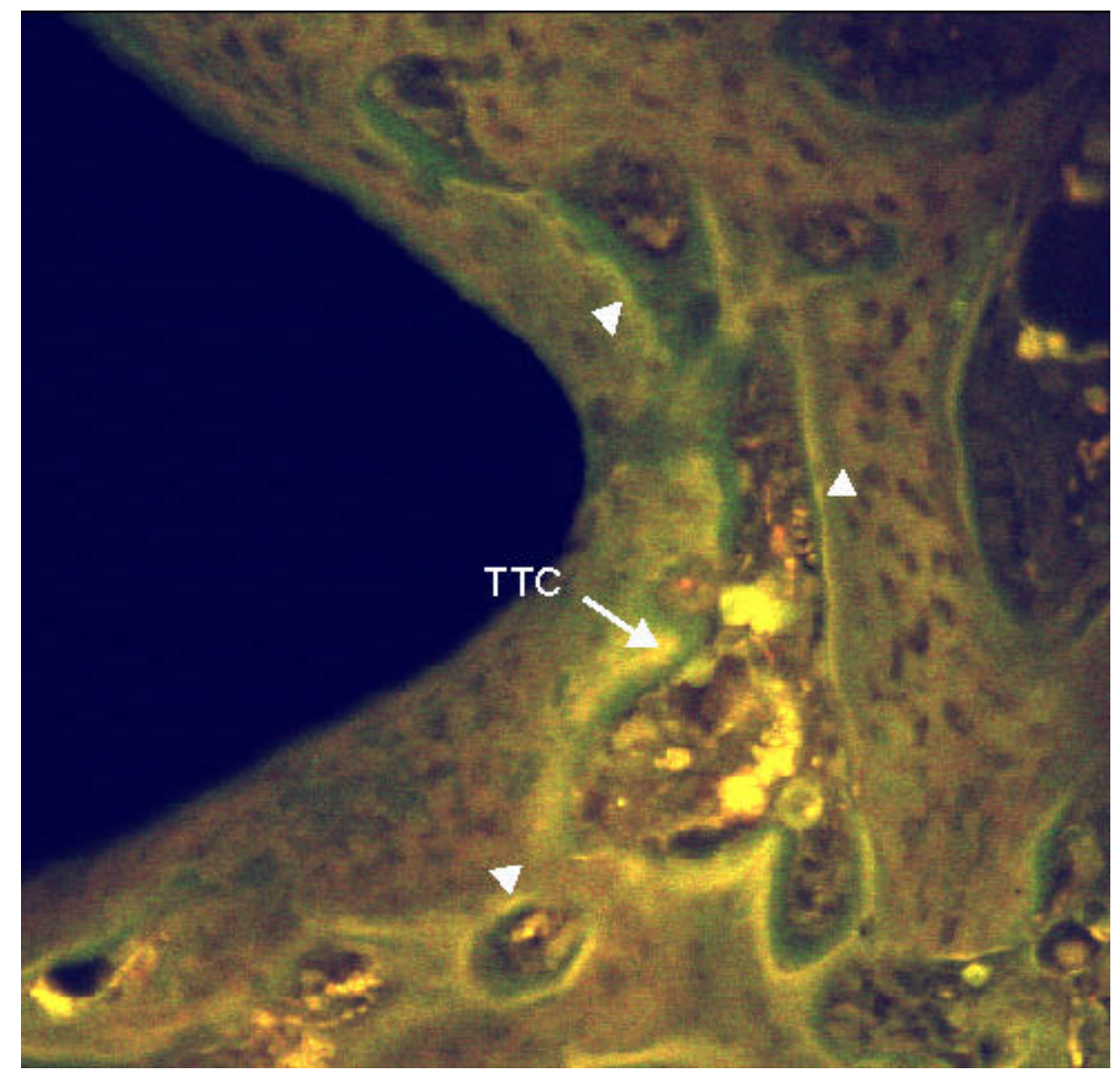

FIGURA 11 - Imagem obtida da região cortical (roscas 1 e 2) da lâmina 1 


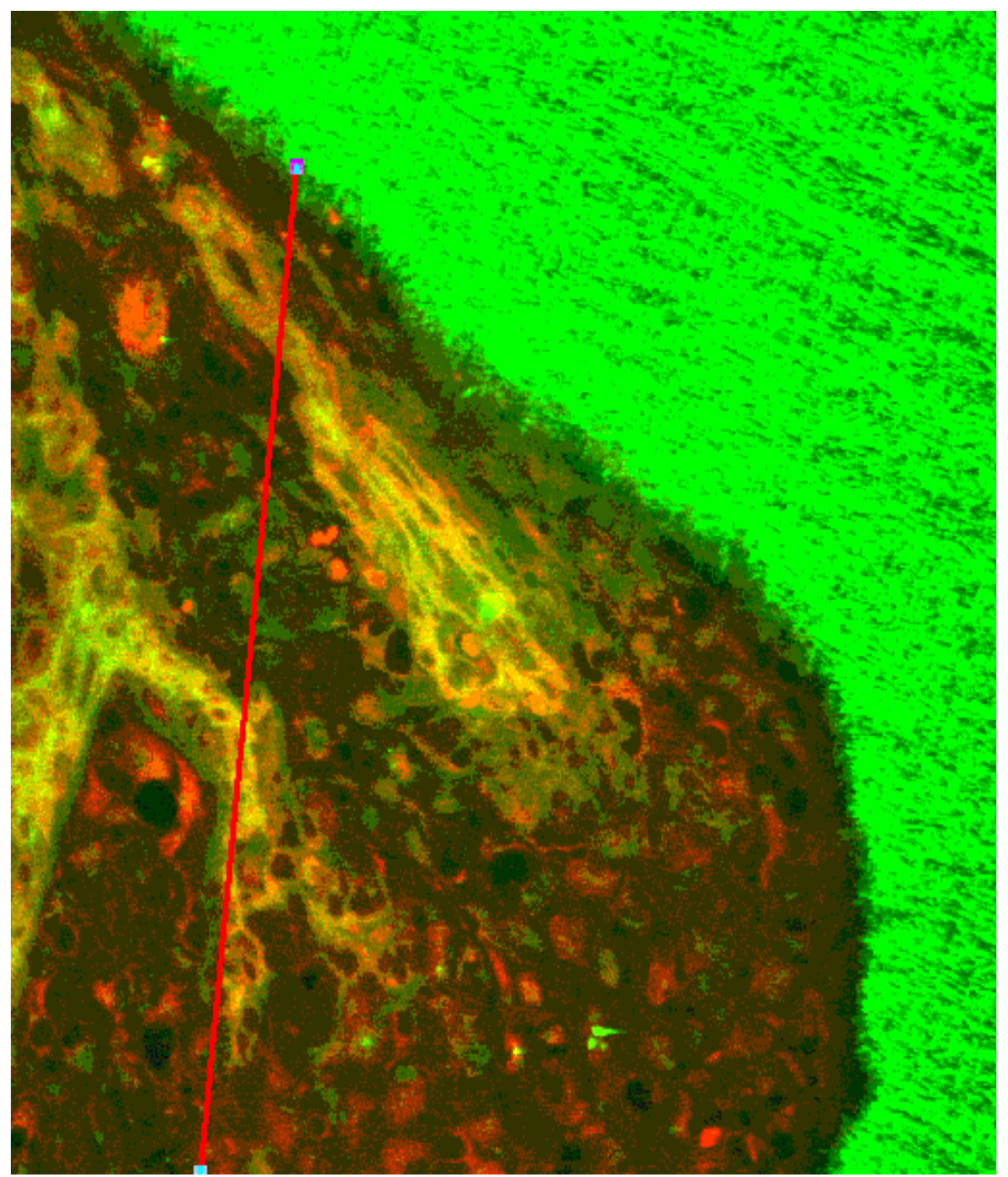

FIGURA 12 - Imagem obtida da região cortical (roscas 1 e 2) da lâmina 1 e respectiva $R O I$ em aumento de 40 vezes 


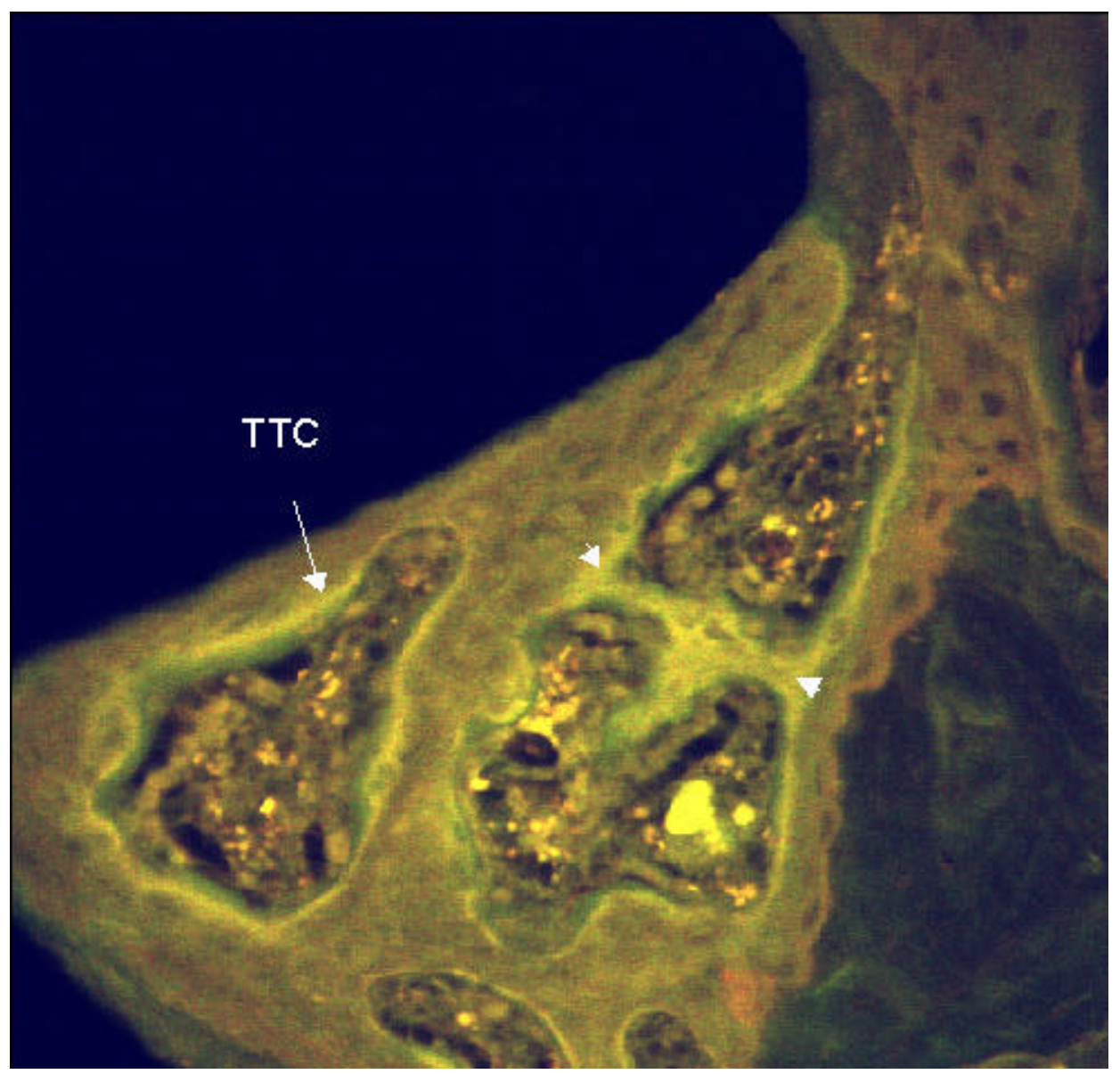

FIGURA 13 - Imagem obtida da região sub-cortical (roscas 3 e 4) da lâmina 1 


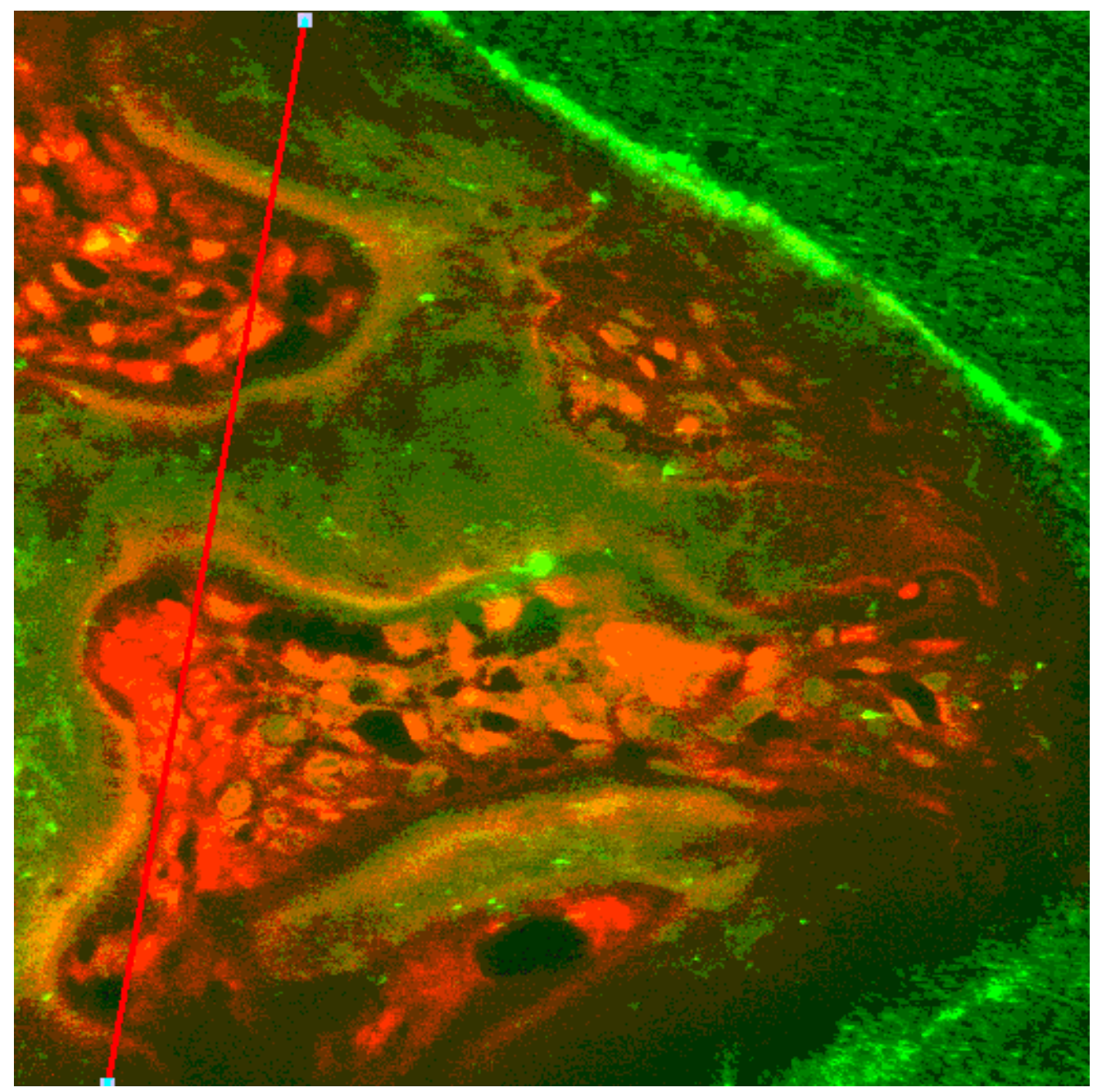

FIGURA 14 - Imagem obtida para a região correspondente às roscas 3 e 4 (região sub-cortical), lâmina 1 e respectiva $R O$ I em aumento de 40 vezes 


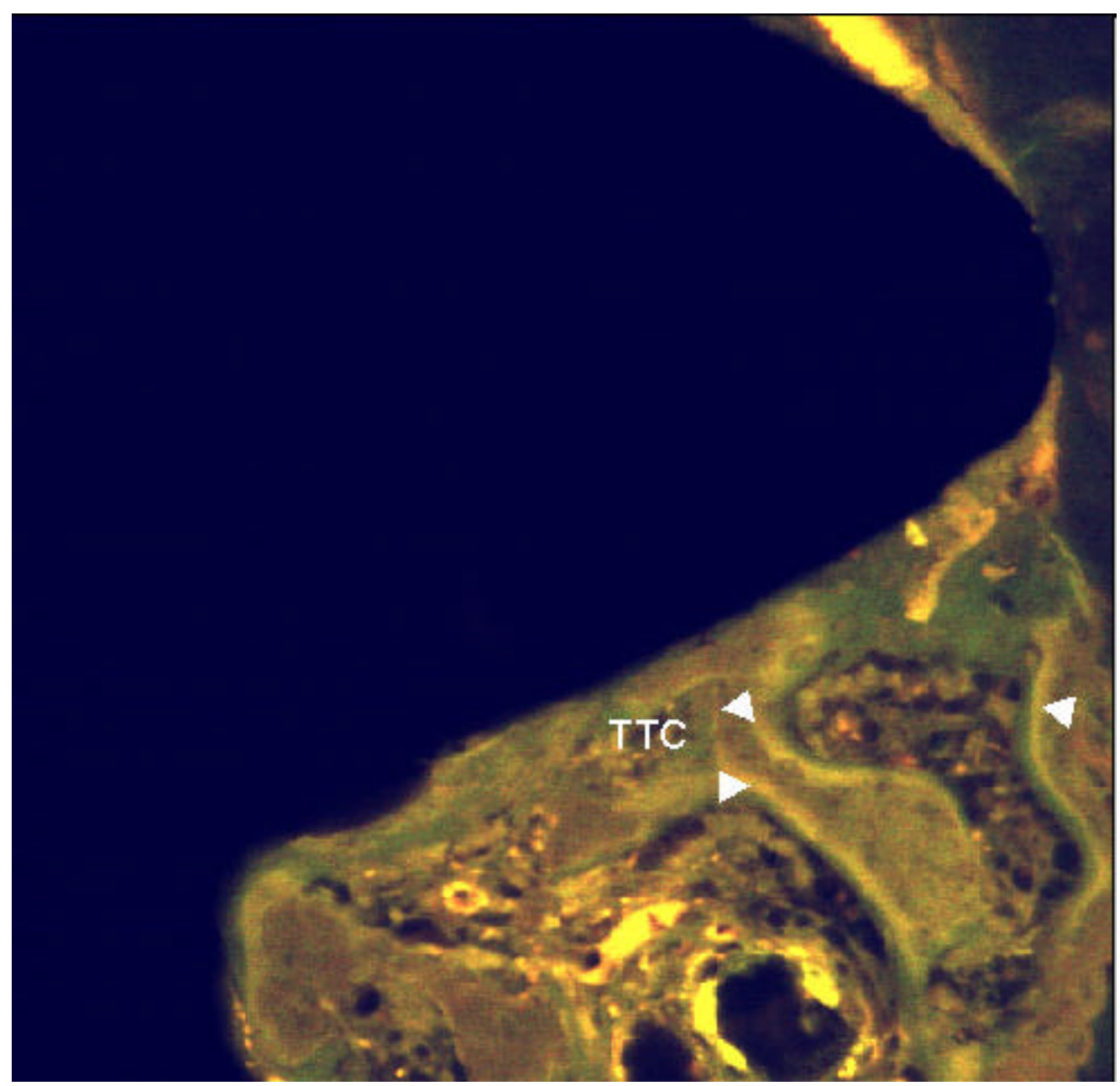

FIGURA 15 - Imagem obtida da região medular (roscas 5 e 6) da lâmina 1 


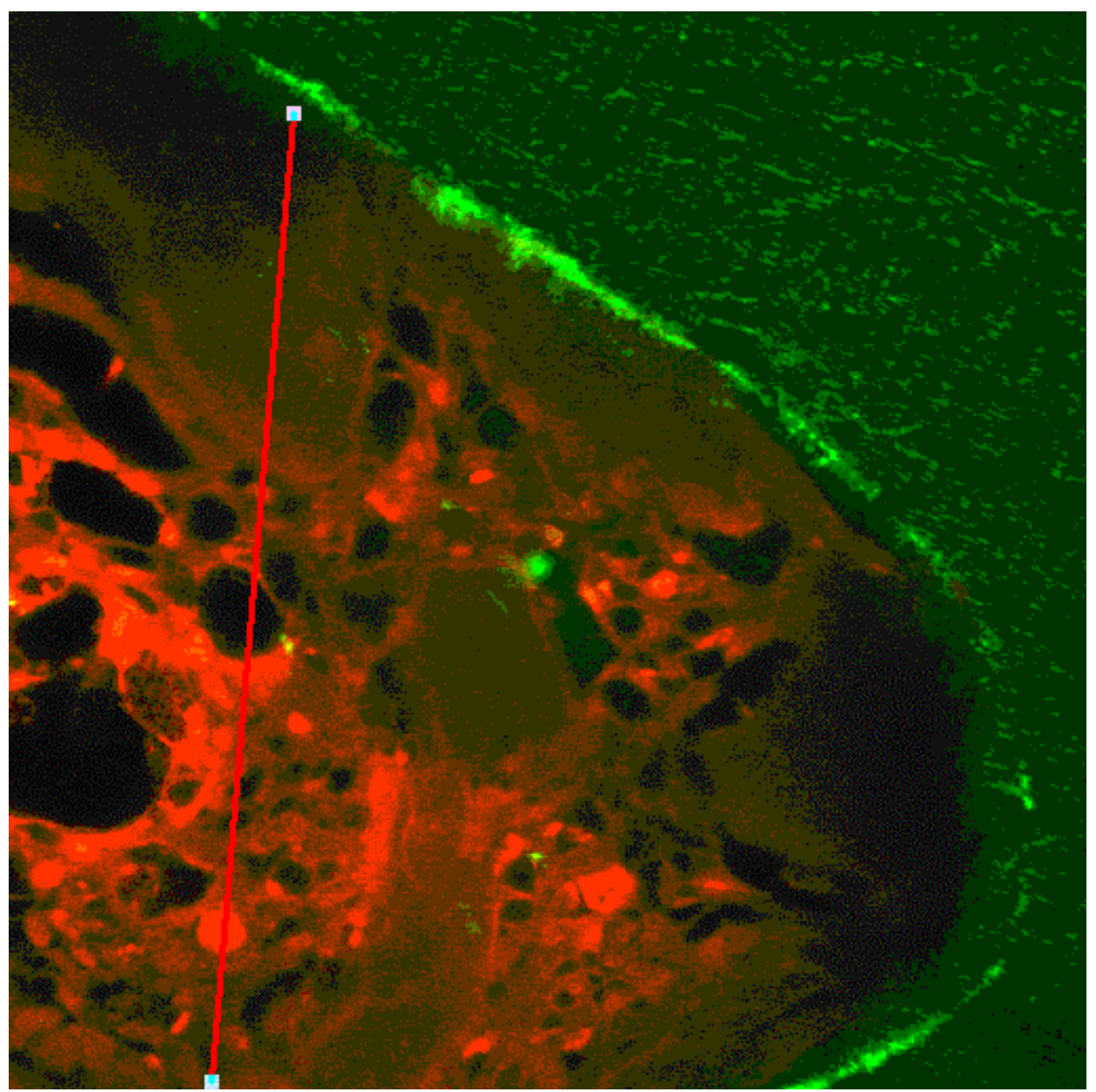

FIGURA 16 -Imagem referente à região medular, lâmina 1 e respectiva $R O$ em aumento de 40 vezes 


\section{Lâmina 3 (observações gerais):}

Observou-se a presença de maior volume ósseo comparativamente àquele existente na lâmina anteriormente descrita. Na região de cortical superior (roscas 1 e 2), notou-se pequena faixa corada com TTC (amarelo) e AL (vermelho) (Figura 17). Em maior aumento, pequenas áreas foram fracamente marcadas, com pequenas áreas concêntricas próximas à superfície do metal. Entre esta e o tecido ósseo parece existir um "gap", correspondente na Figura 18 à área escura. Não há distinção entre as camadas de AL e TTC. As áreas em verde representam pontos de reflexão. $\mathrm{Na}$ região correspondente às roscas 3 e 4 , observa-se a presença de tecido ósseo na rosca 4, com algumas áreas marcadas com AL. Por outro lado, a rosca 3 parece estar preenchida por material amorfo, não sendo possível a identificação de qualquer dos marcadores (Figura 19). Em maior aumento, pode-se observar a presença de áreas concêntricas marcadas com TTC em regiões próximas à superfície da rosca, porém com $b$ rilho em baixa intensidade. As regiões coradas em vermelho $(A L)$ localizam-se posteriormente às anteriores e também apresentam baixa intensidade de brilho (Figura 20). Na região medular (roscas 5 e 6), observa-se mais volume ósseo na rosca 5 em relação à rosca 6 , apresentando algumas regiões marcadas com $A L$, não sendo possível a distinção de TTC (Figura 21). Em maior aumento, nota-se a presença de pequenas áreas concêntricas regulares coradas com $\mathrm{AL}$ próximas à superfície do implante e uma região mais extensa e ligeiramente mais afastada da superfície do implante também corada com AL. Não há distinção de TTC (Figura 22). 


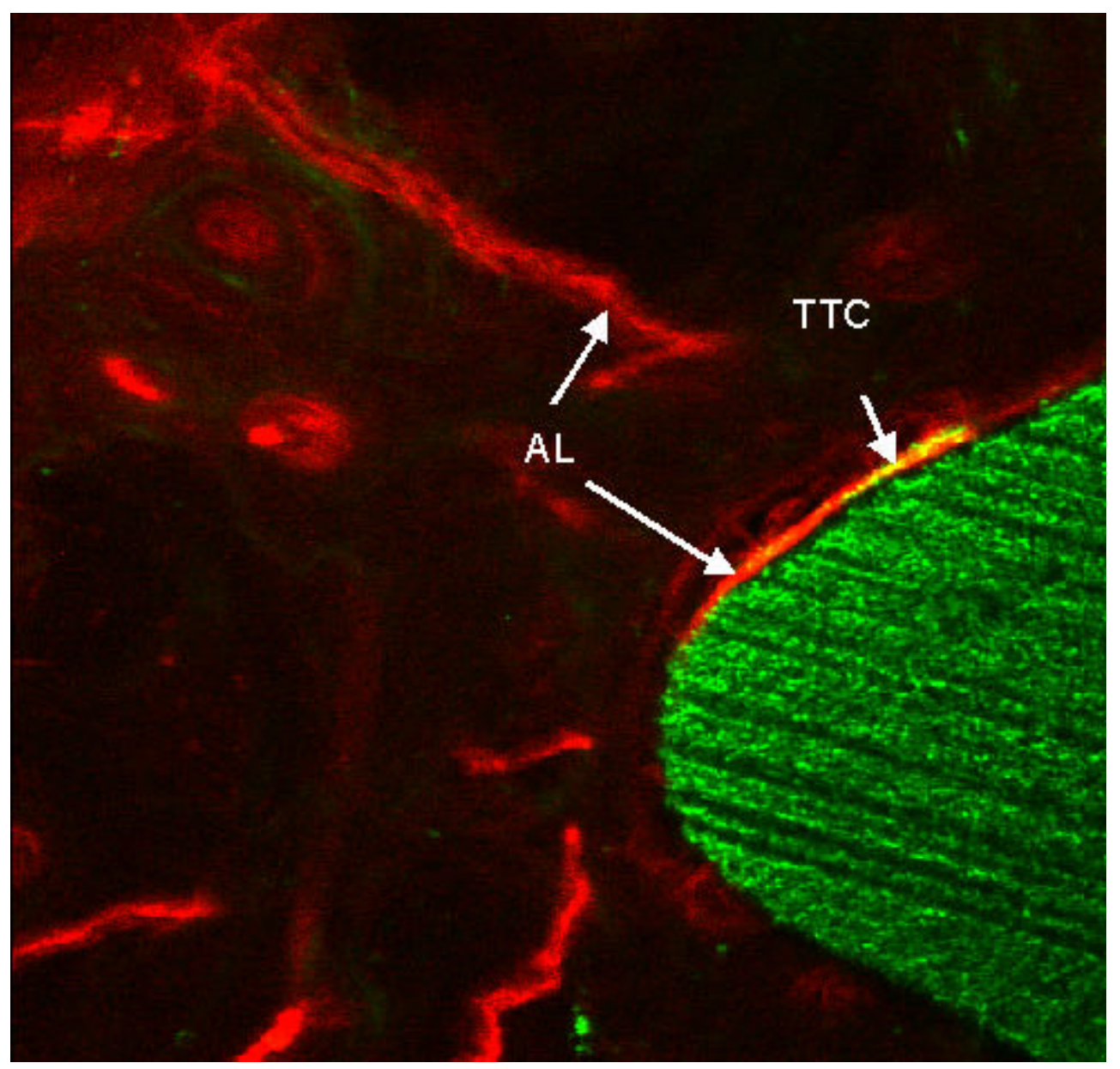

FIGURA 17 - Imagem obtida da região cortical (roscas 1 e 2) da lâmina 3 


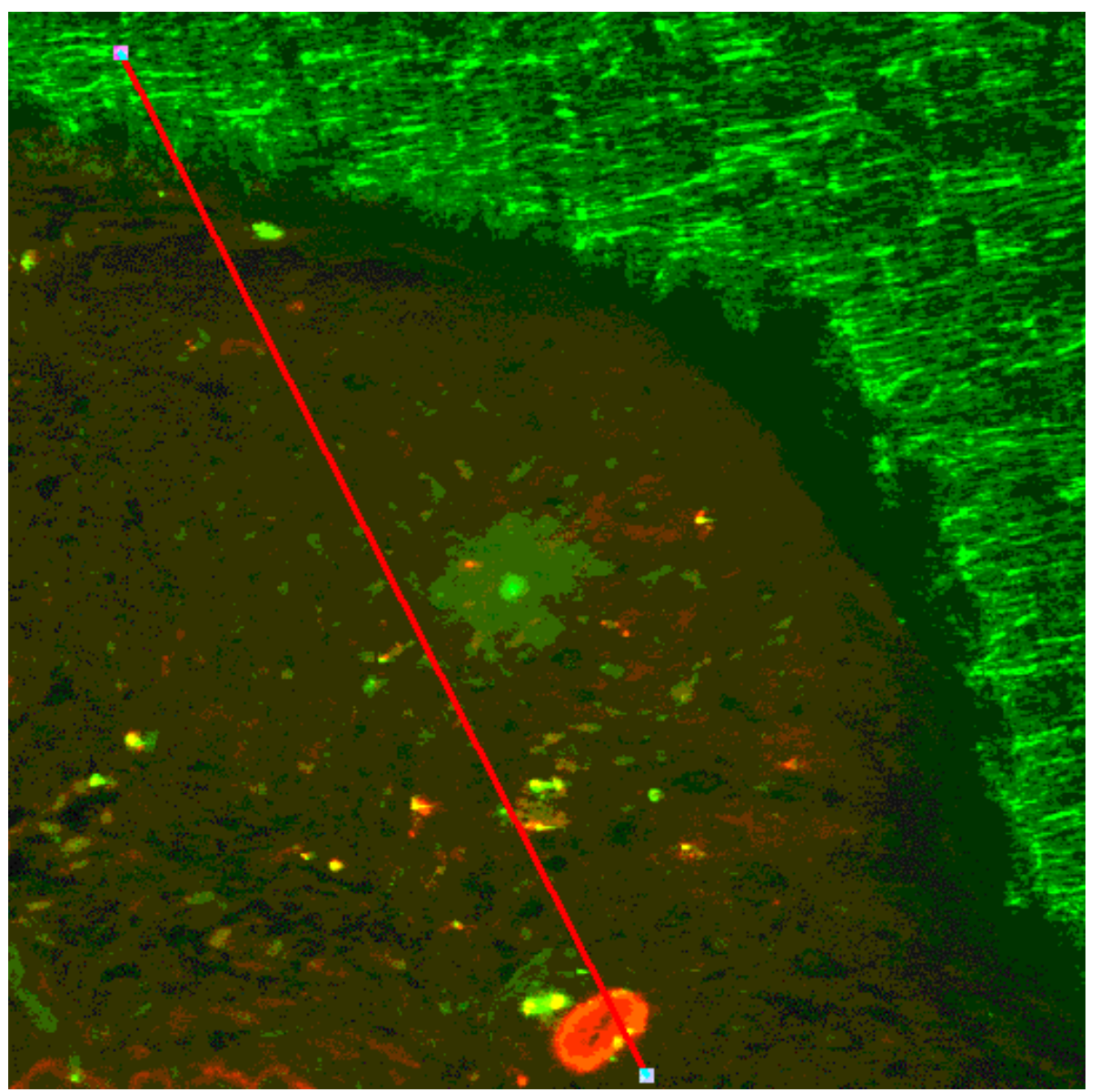

FIGURA 18 - Imagem obtida para a região cortical, lâmina 3 e respectiva $R O I$, em aumento de 40 vezes 


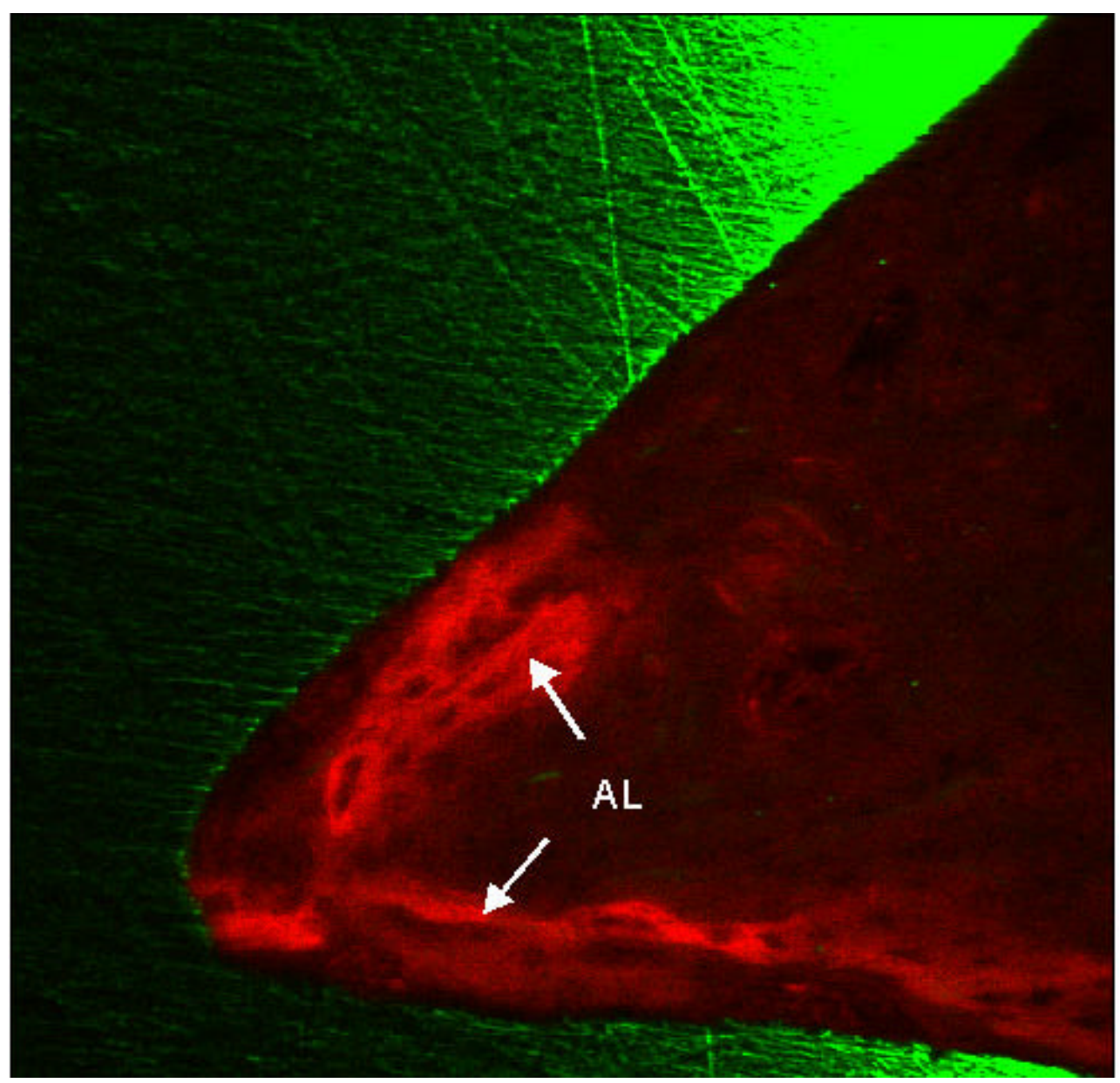

FIGURA 19 - Imagem obtida da região sub-cortical (roscas 3 e 4) da lâmina 3 


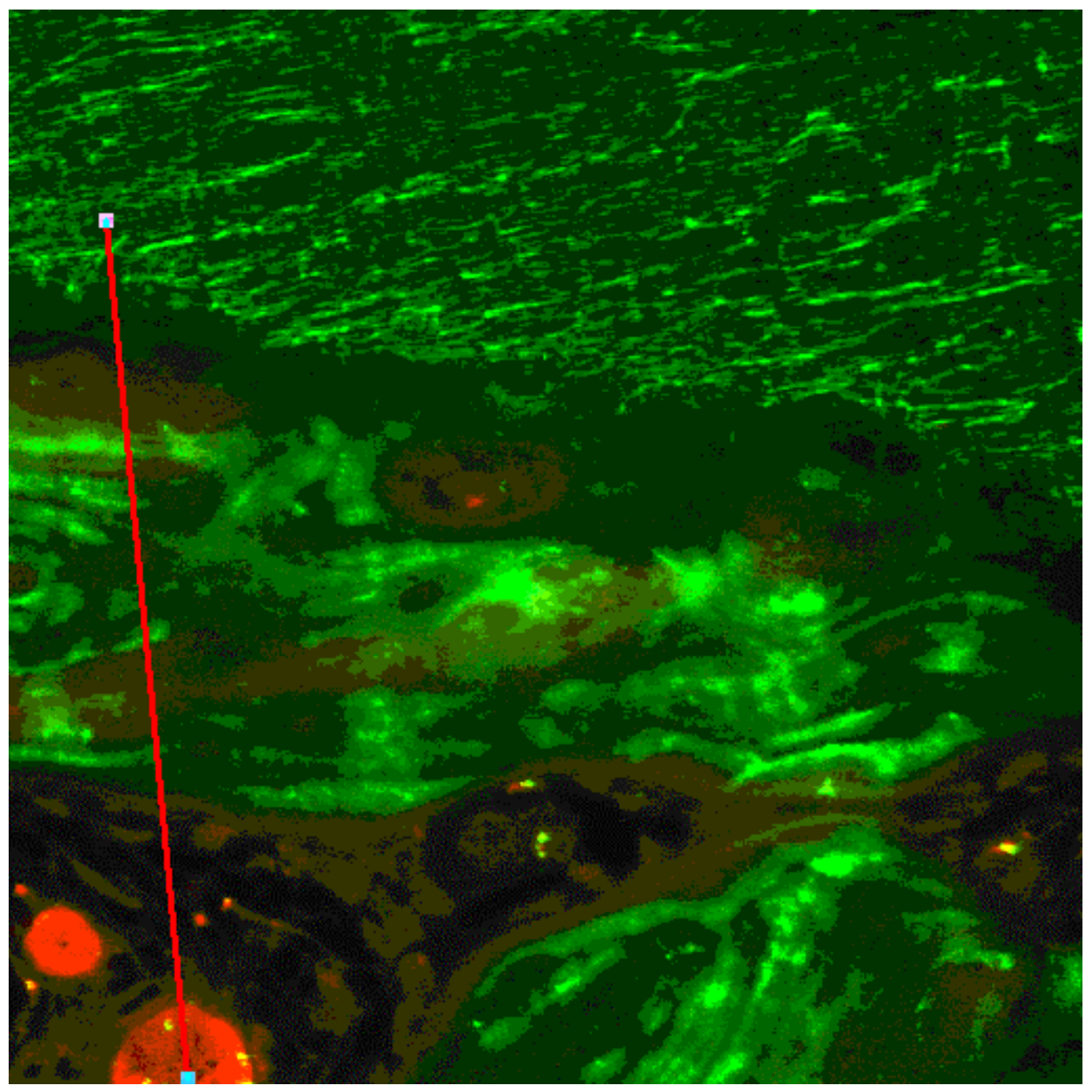

FIGURA 20 - Imagem obtida para a região sub-cortical, lâmina 3 e respectiva ROI em aumento de 40 vezes 


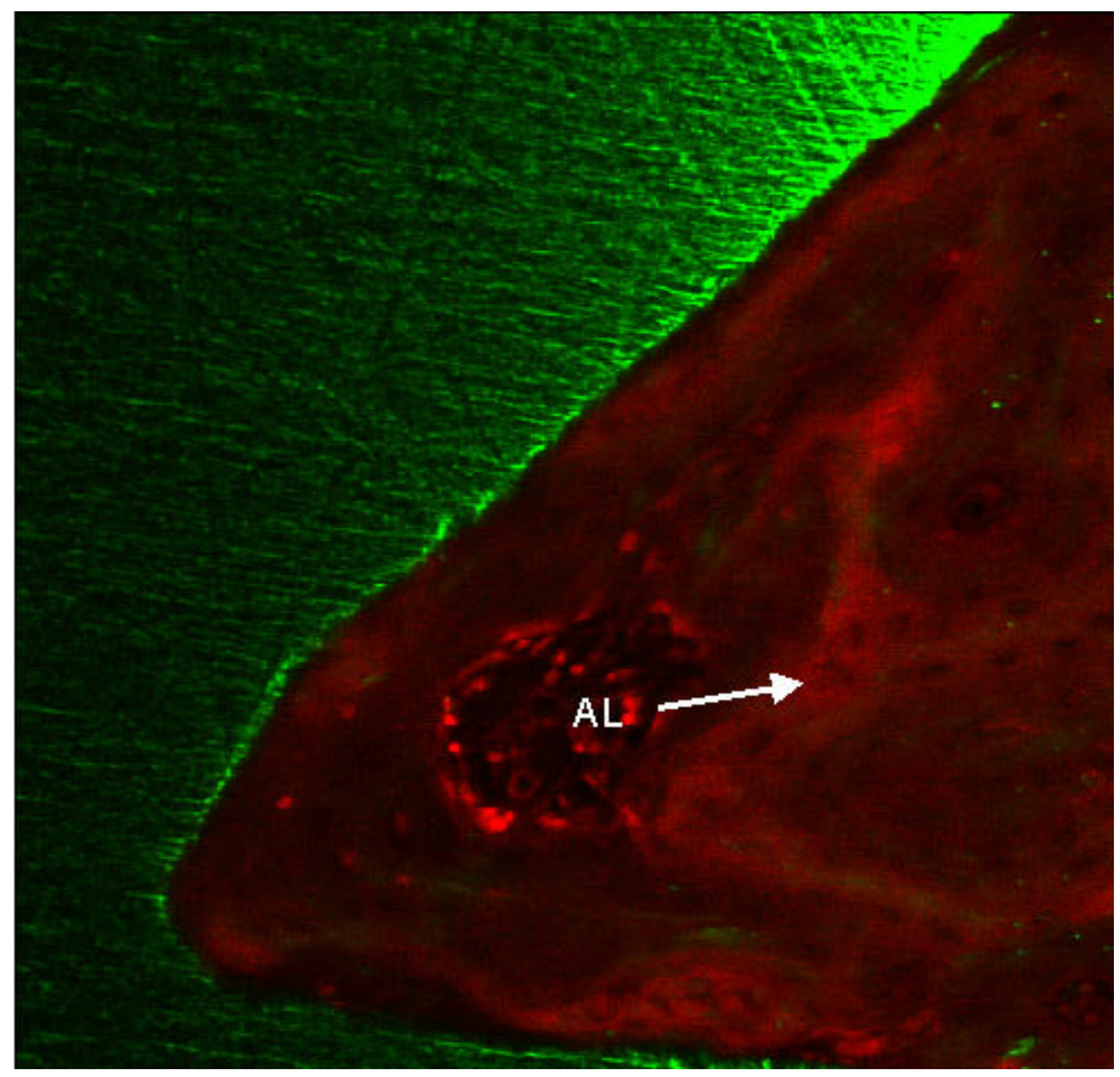

FIGURA 21 - Imagem obtida da região medular (roscas 5 e 6) da lâmina 3 


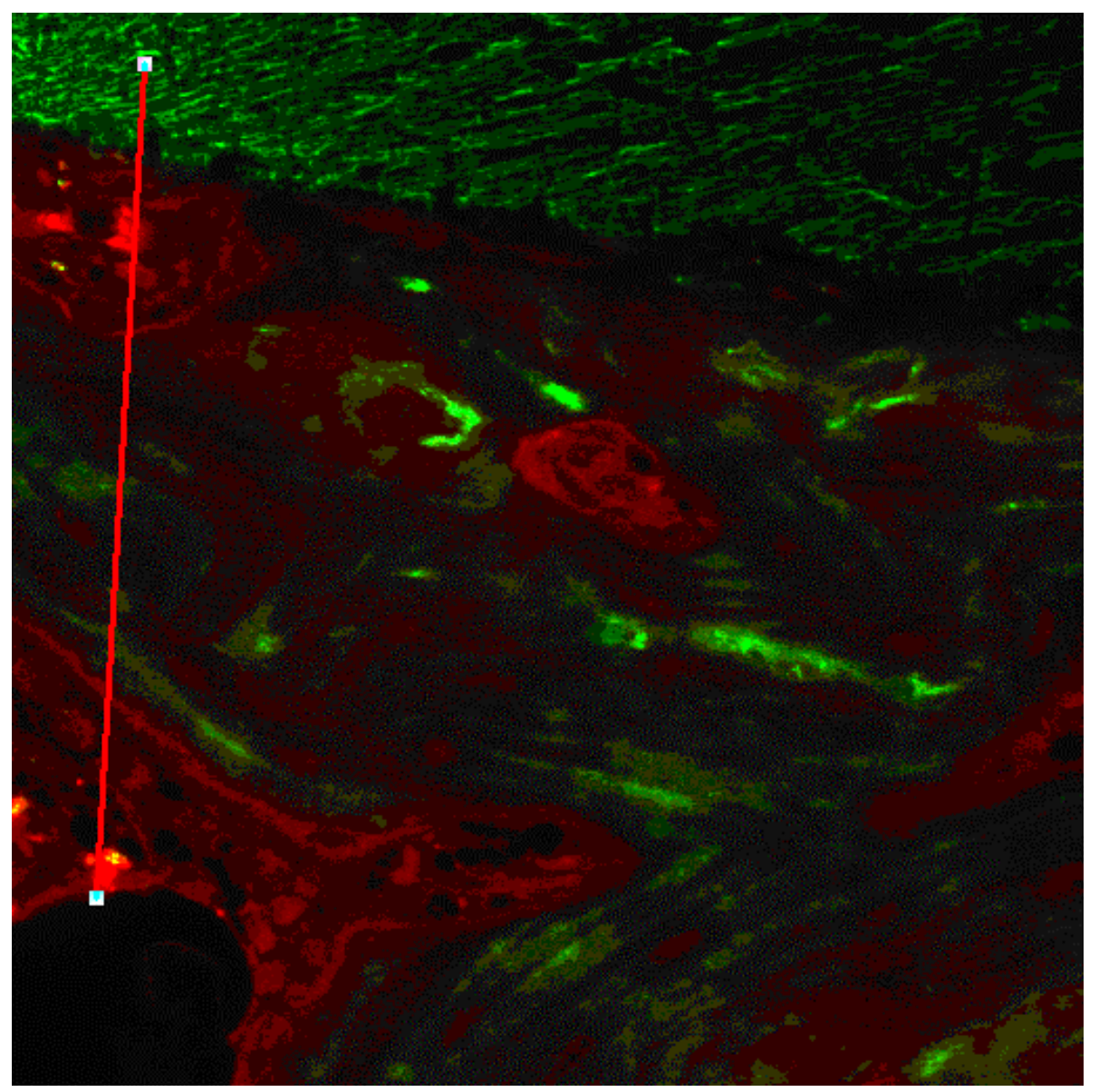

FIGURA 22 - Imagem obtida da região medular, lâmina 3 e respectiva $R O$ em aumento de 40 vezes 


\section{Lâmina 4 (observações gerais):}

O padrão geral apresentado nesta lâmina foi semelhante à anterior. Na região cortical (roscas 1 e 2), pequenas regiões apresentaram marcação específica para $A L$, especialmente aquelas correspondentes às paredes de canais vasculares intra-ósseos, podendo-se observar a existência de uma área mais externa e outra mais internamente localizada, separadas entre si por distância de 7,9 $\mu \mathrm{m}$, não sendo possível a distinção das camadas de TTC (Figura 23). Em maior aumento, observase a presença de áreas concêntricas bem definidas, com brilho intenso de AL, sem distinção de TTC. Também é possível a visualização de um "gap" entre o metal e o tecido ósseo (Figura 24). Na rosca 3, observa-se maior volume ósseo do que na rosca 4, apresentando marcação para $\mathrm{AL}$ em maior intensidade comparativamente à área cortical, não sendo possível a distinção com TTC (Figura 25). Em maior aumento, observa-se a existência de duas camadas, sendo uma camada com $A L$ e outra com TTC (Figura 26). As roscas 5 e 6 não apresentaram áreas marcadas, estando preenchidas por material amorfo (Figura 27). 


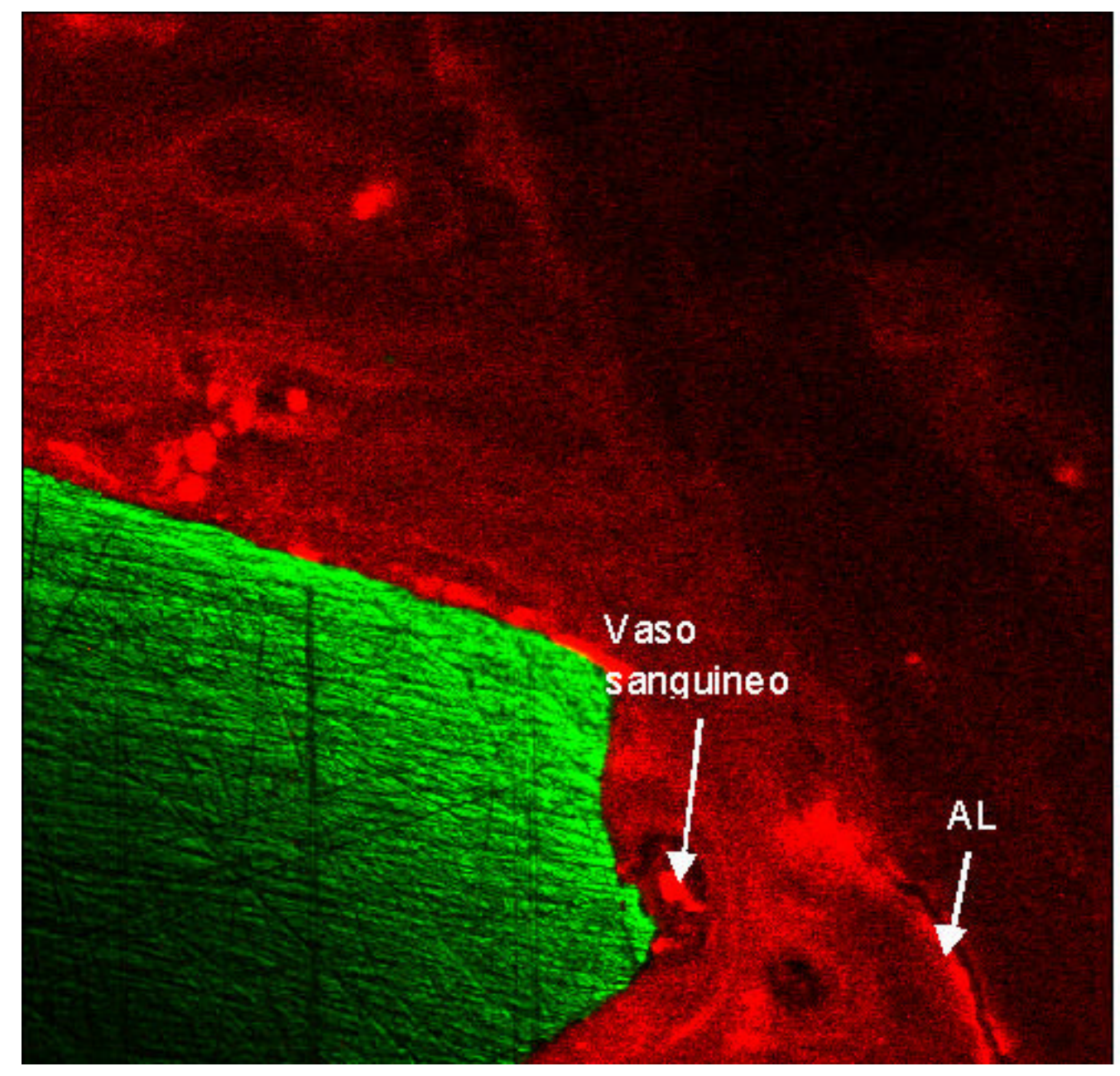

FIGURA 23 - Imagem obtida da região cortical (roscas 1 e 2) da lâmina 4 


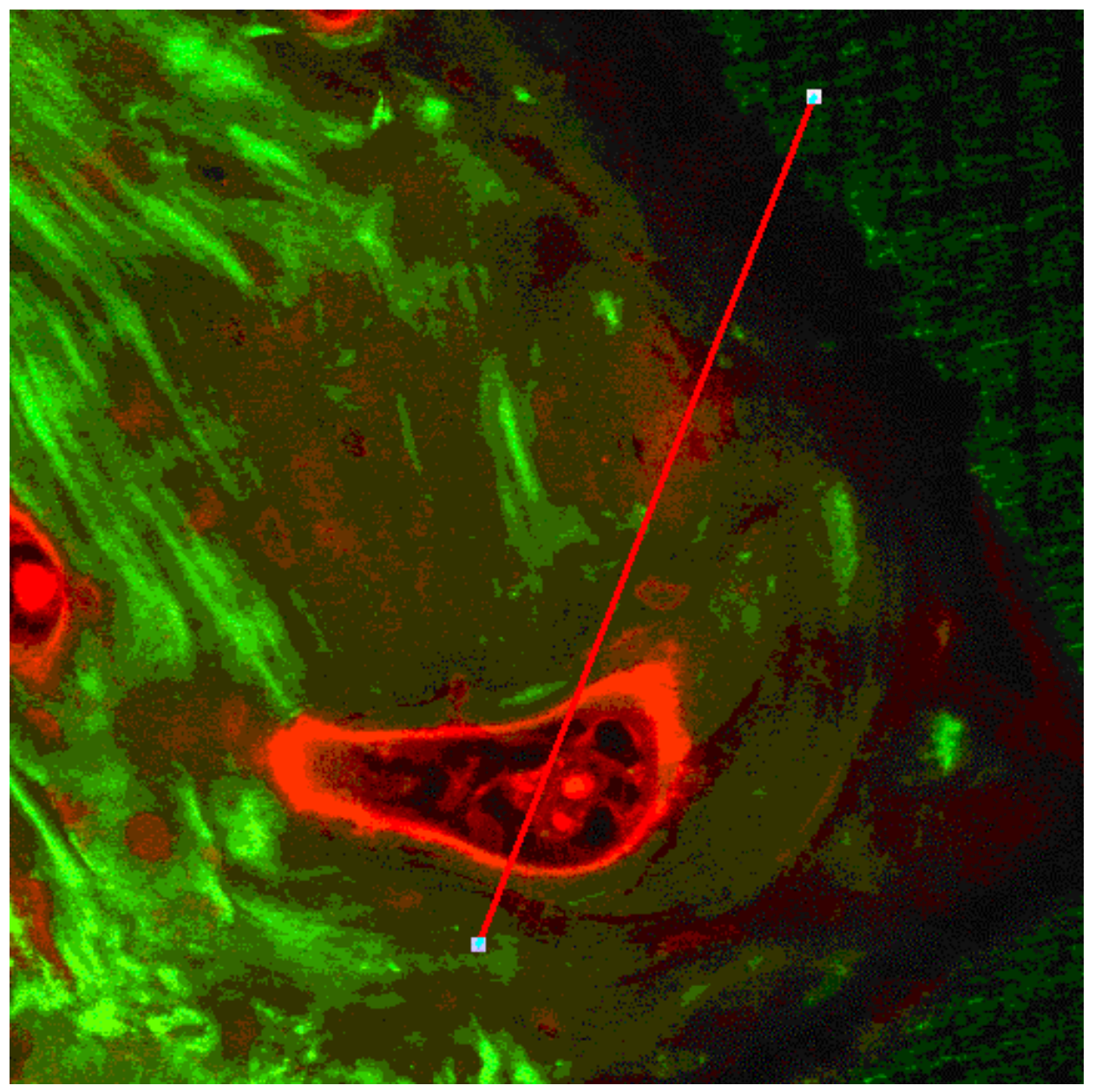

FIGURA 24-Imagem obtida da região cortical, lâmina 4 e respectiva $R O$ em aumento de 40 vezes 


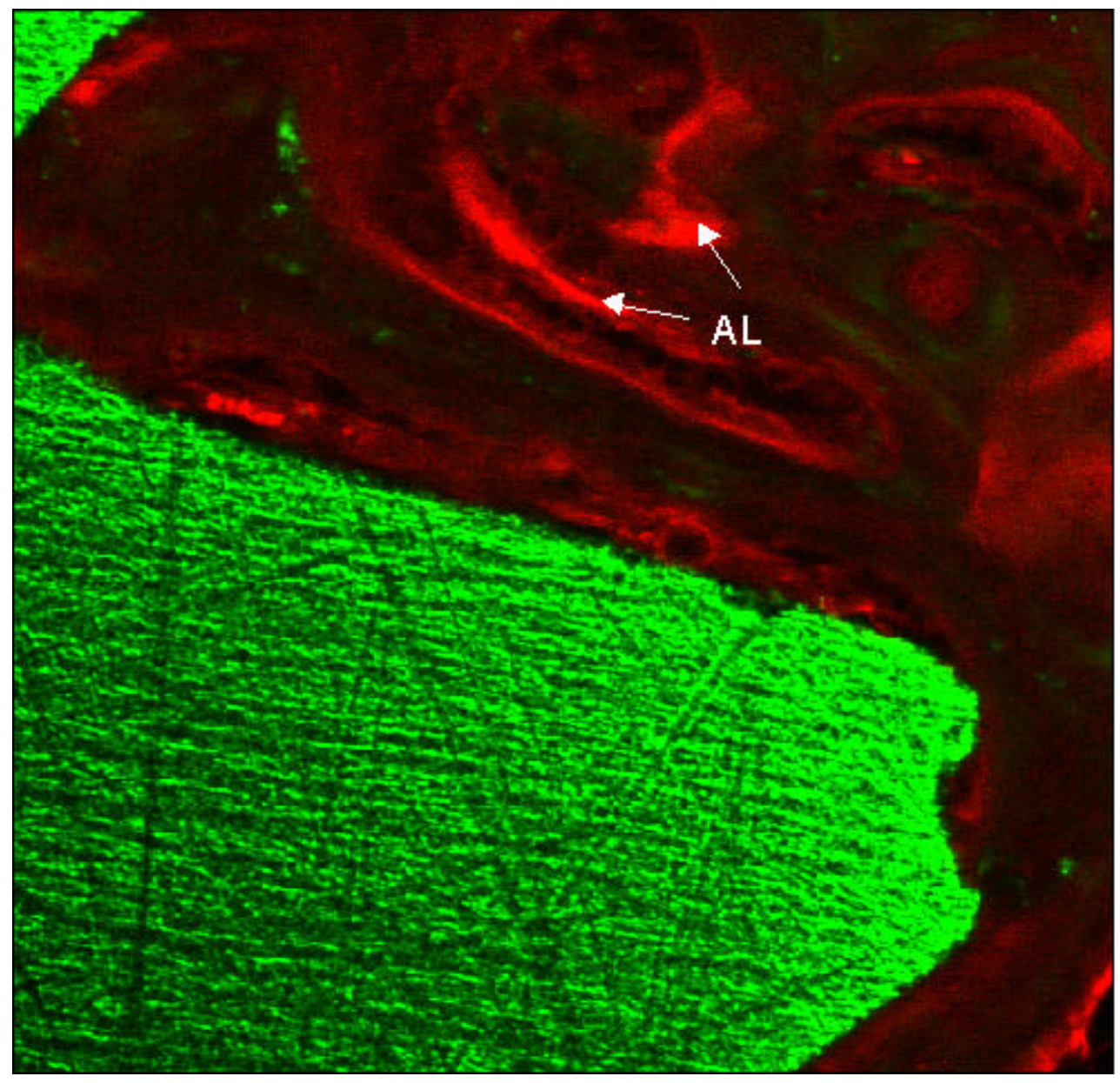

FIGURA 25 - Imagem obtida da região sub-cortical (roscas 3 e 4) da lâmina 4 


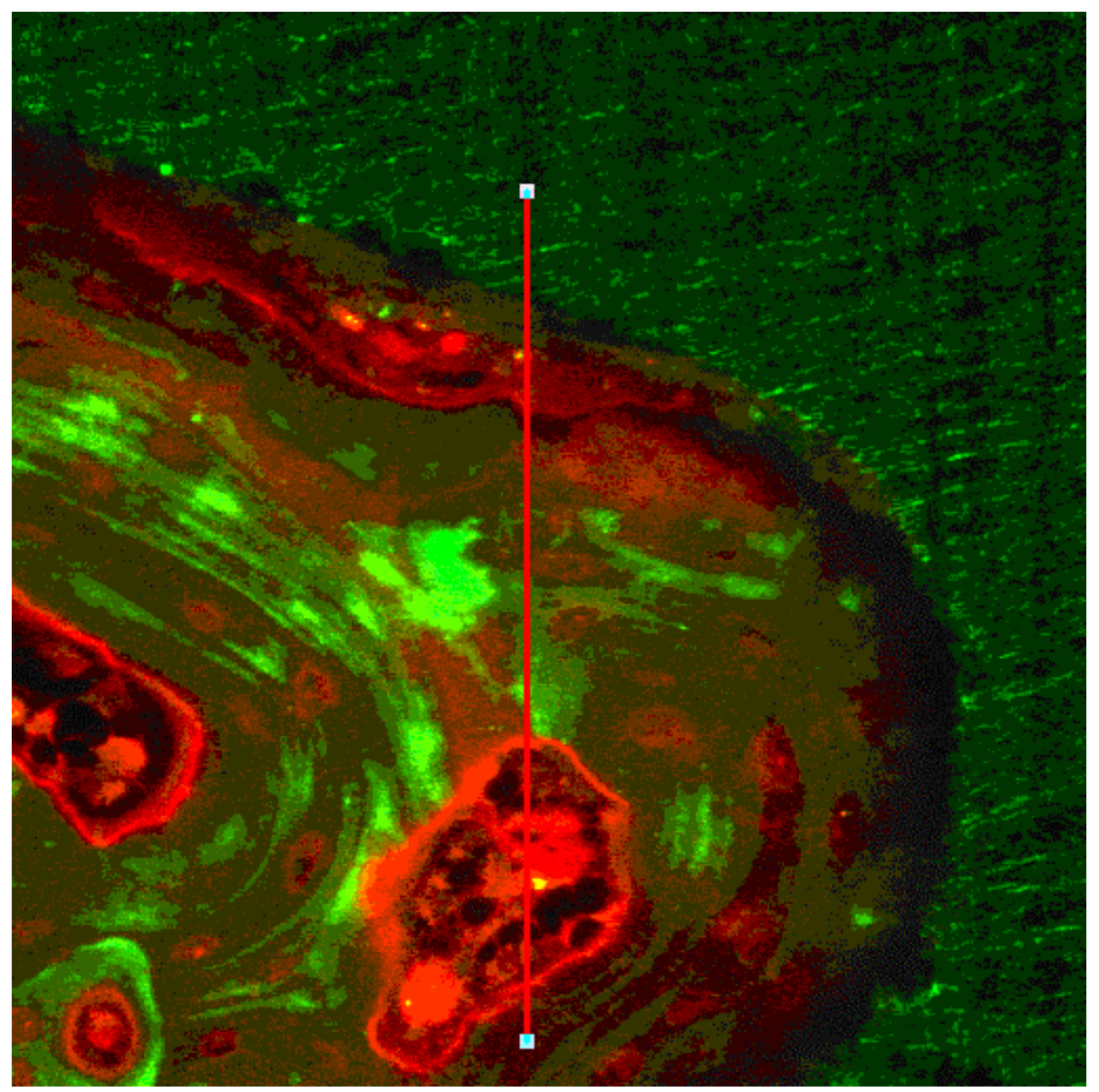

FIGURA 26 - Imagem obtida da região sub-cortical, lâmina 4 e respectiva $R O I$ em aumento de 40 vezes

FIGURA 27 - Região medular - lâmina 4 - imagem amorfa - não incluída na avaliação 


\section{Lâmina 5 (observações gerais):}

Pode-se observar nas roscas correspondentes à região cortical a presença de CAL e AL em pequenas quantidades. Comparativamente às lâminas avaliadas anteriormente, nota-se maior quantidade de tecido ósseo ao redor de todo o implante. Nas roscas 1 e 2, distingue-se camadas de AL e TTC (Figura 28). Em maior aumento, observa-se a presença de AL e TTC próxima à superfície do metal. Em outras regiões, nota-se área marcada por TTC e CAL. Também visualiza-se a presença de áreas pequenas e arredondadas, coradas internamente por CAL e externamente por TTC e/ou AL (Figura 29). Na região sub-cortical em aumento de 20 vezes, as áreas marcadas com calceína estão separadas por uma distância de 698,62 $\mu \mathrm{m}$ (Figura 30), enquanto que, em aumento de 40 vezes, observase extensas áreas coradas externamente por TTC e internamente por CAL, não sendo possível a identificação de AL. Uma única região apresenta uma pequena área marcada com AL, embora de brilho pouco intenso e de pequena extensão (Figura 31). Em pequeno aumento, na área medular, mais próximo à cortical inferior, observa-se a presença de $A L$, TTC e CAL próximos à superfície do metal e pequenas áreas concêntricas marcadas com AL e CAL (Figura 32) e, em maior aumento, estas mesmas características podem ser visualizadas. Nota-se uma região de formato arredondado bem definido, marcada externamente por TTC (em amarelo) e internamente por CAL (em verde), provavelmente correspondente à luz de um vaso sangüíneo, sem se identificar a presença de AL (Figura 33). 


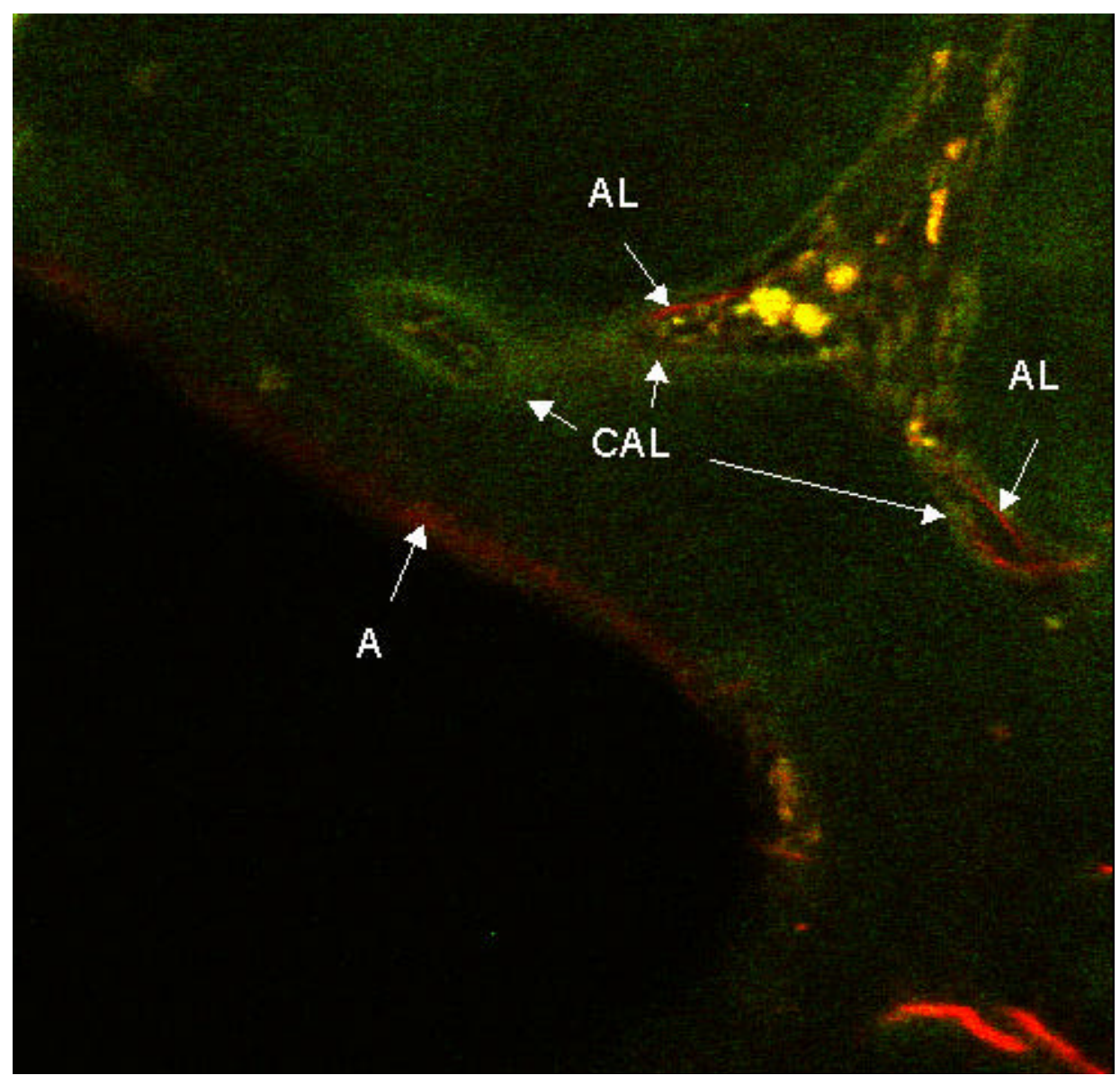

FIGURA 28 - Imagem obtida da região cortical (roscas 1 e 2) da lâmina 5 


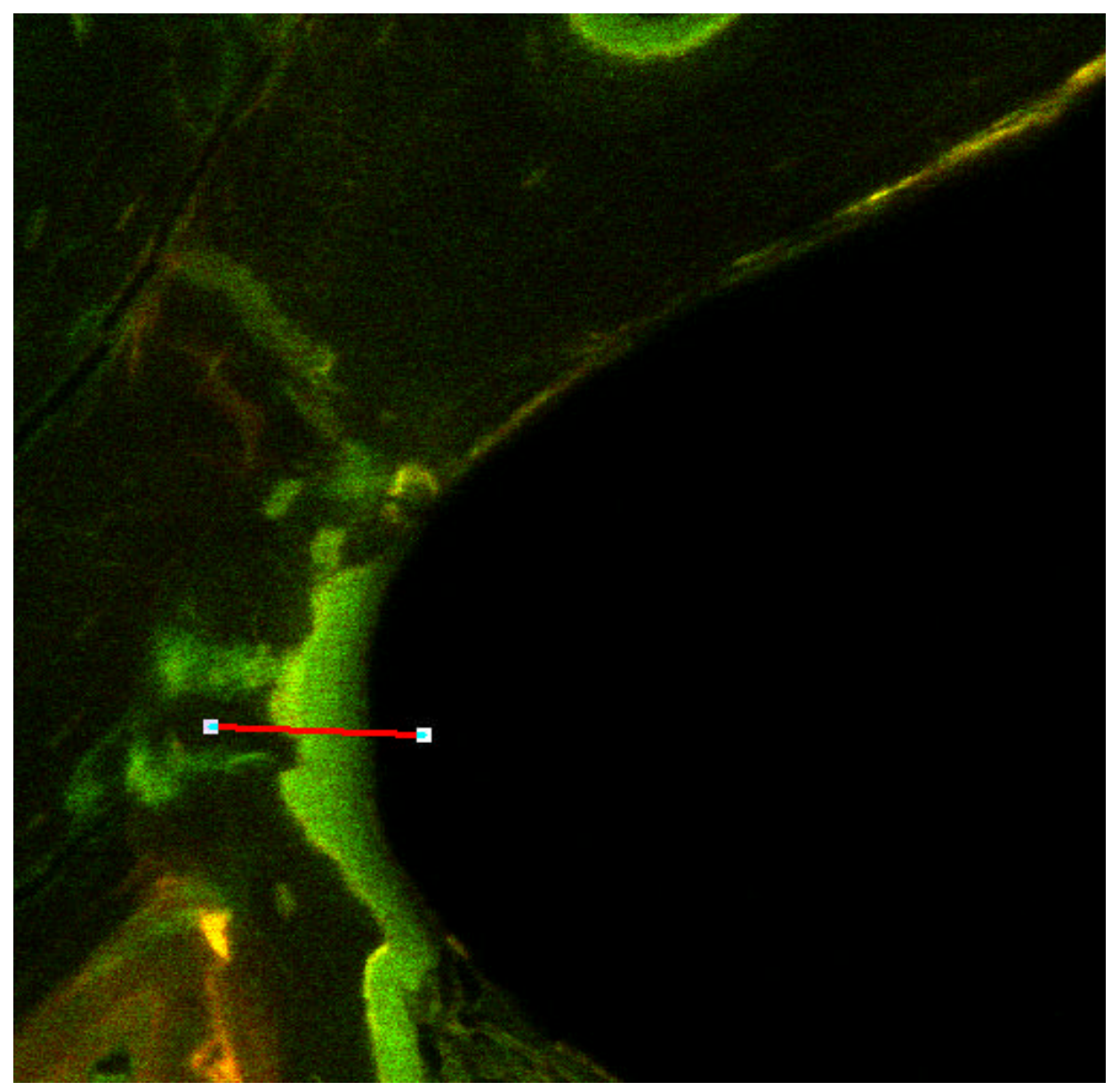

FIGURA 29 - Imagem em aumento de 40 vezes obtido da região cortical da lâmina 5 


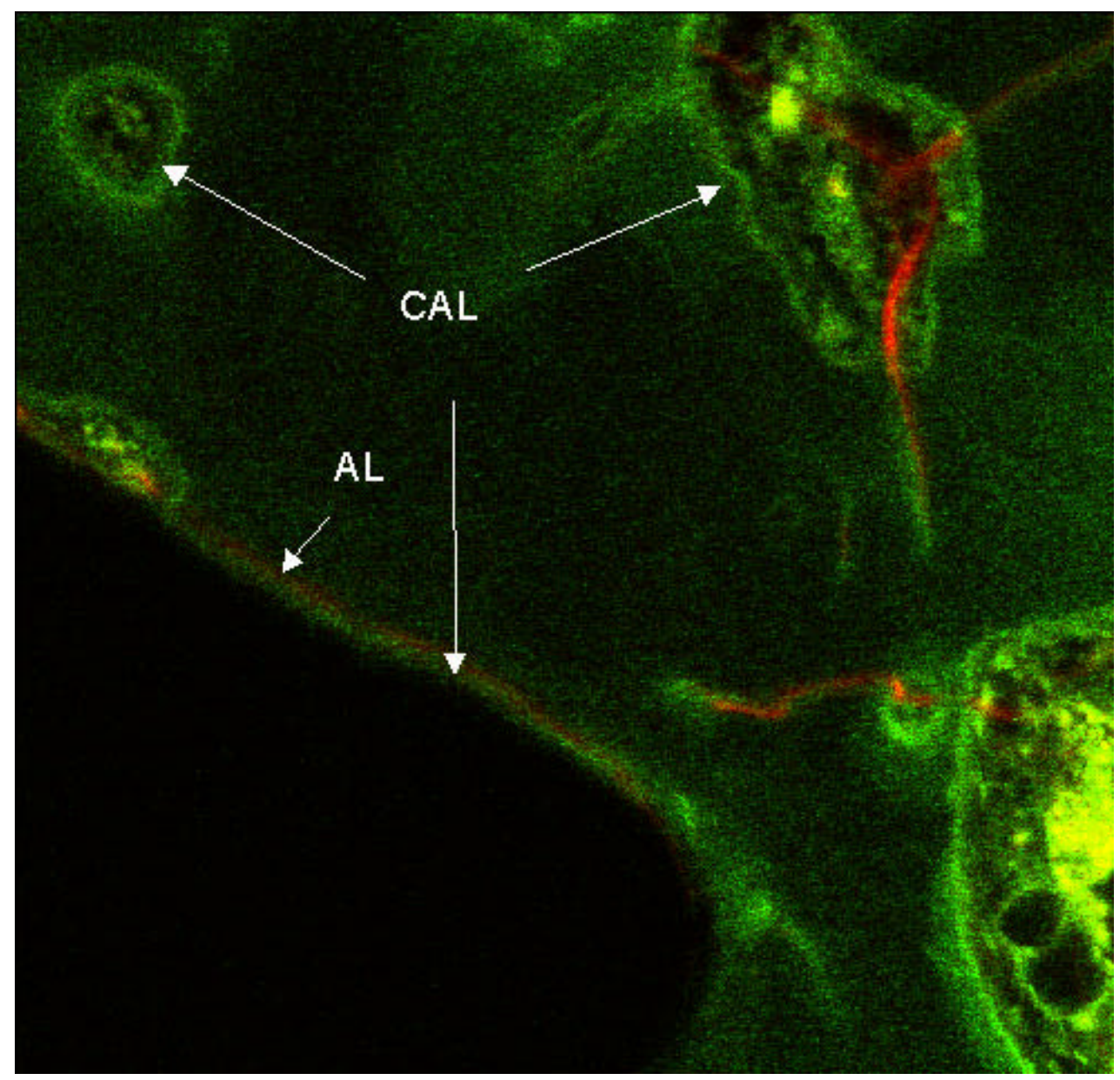

FIGURA 30 - Imagem obtida da região sub-cortical (roscas 3 e 4) da lâmina 5 


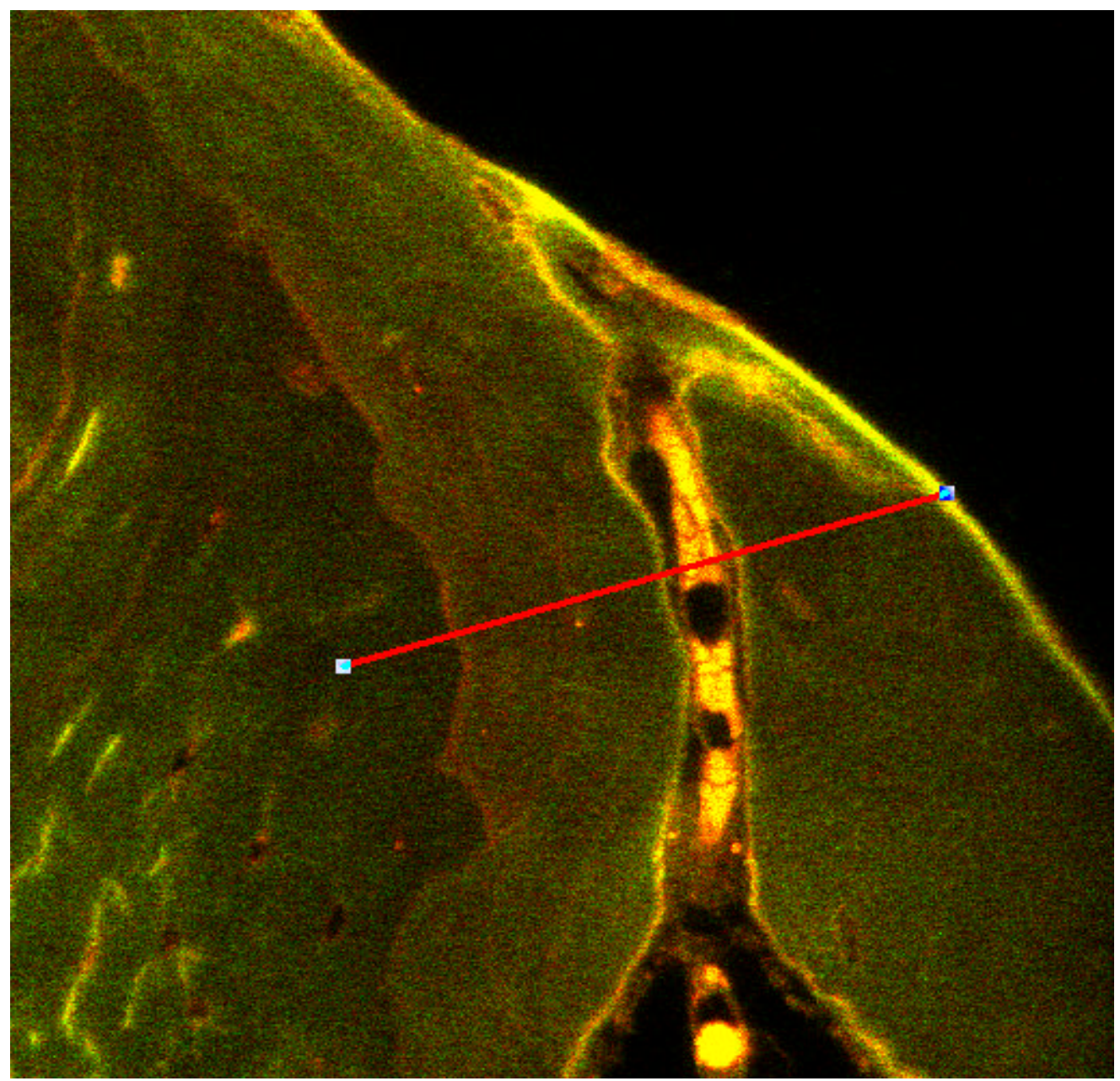

FIGURA 31 - Imagem obtida da região sub-cortical, lâmina 5 e respectiva $R O$ em aumento de 40 vezes 


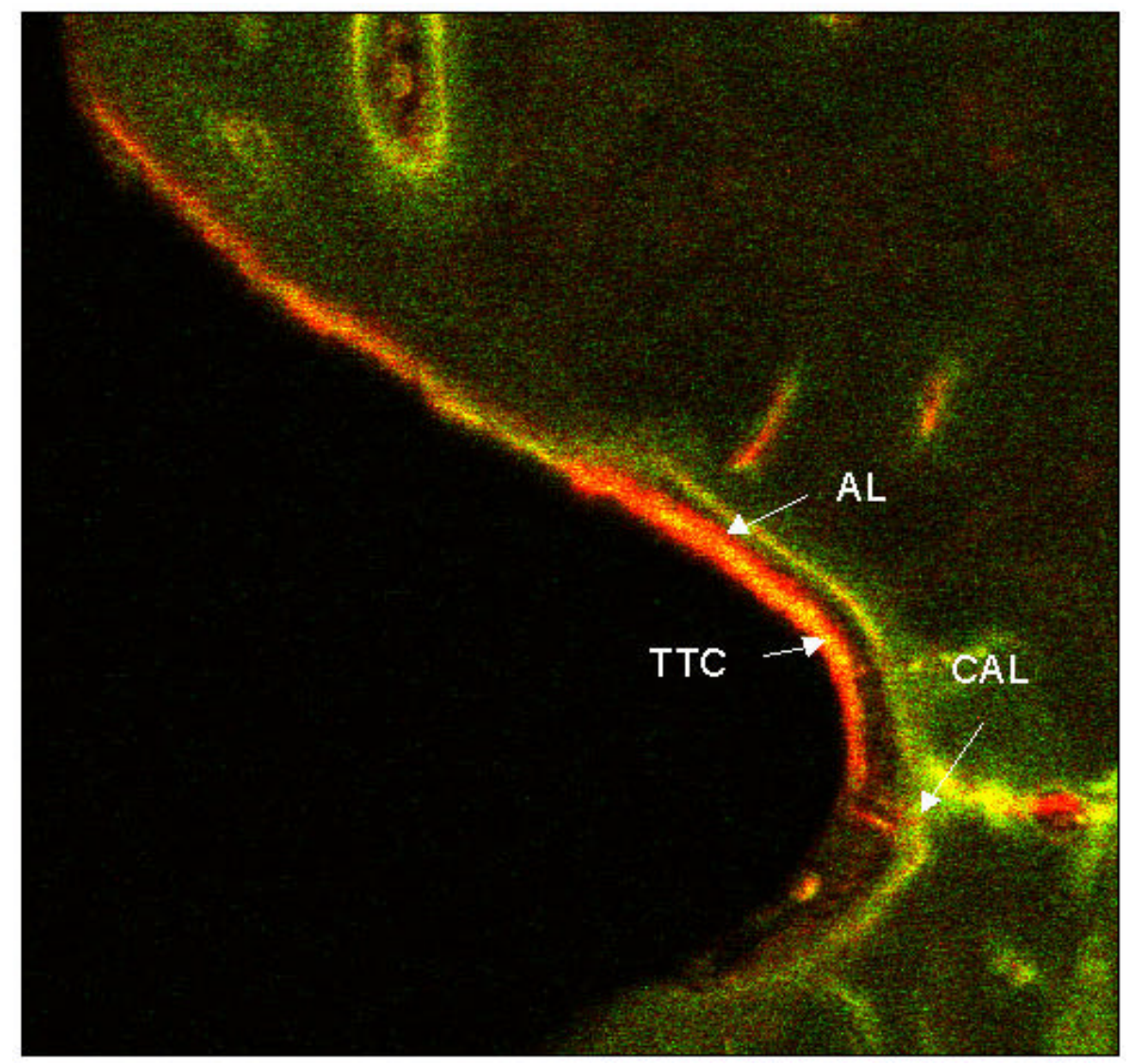

FIGURA 32 - Imagem obtida da região medular (rosca 5 e 6) da lâmina 5 


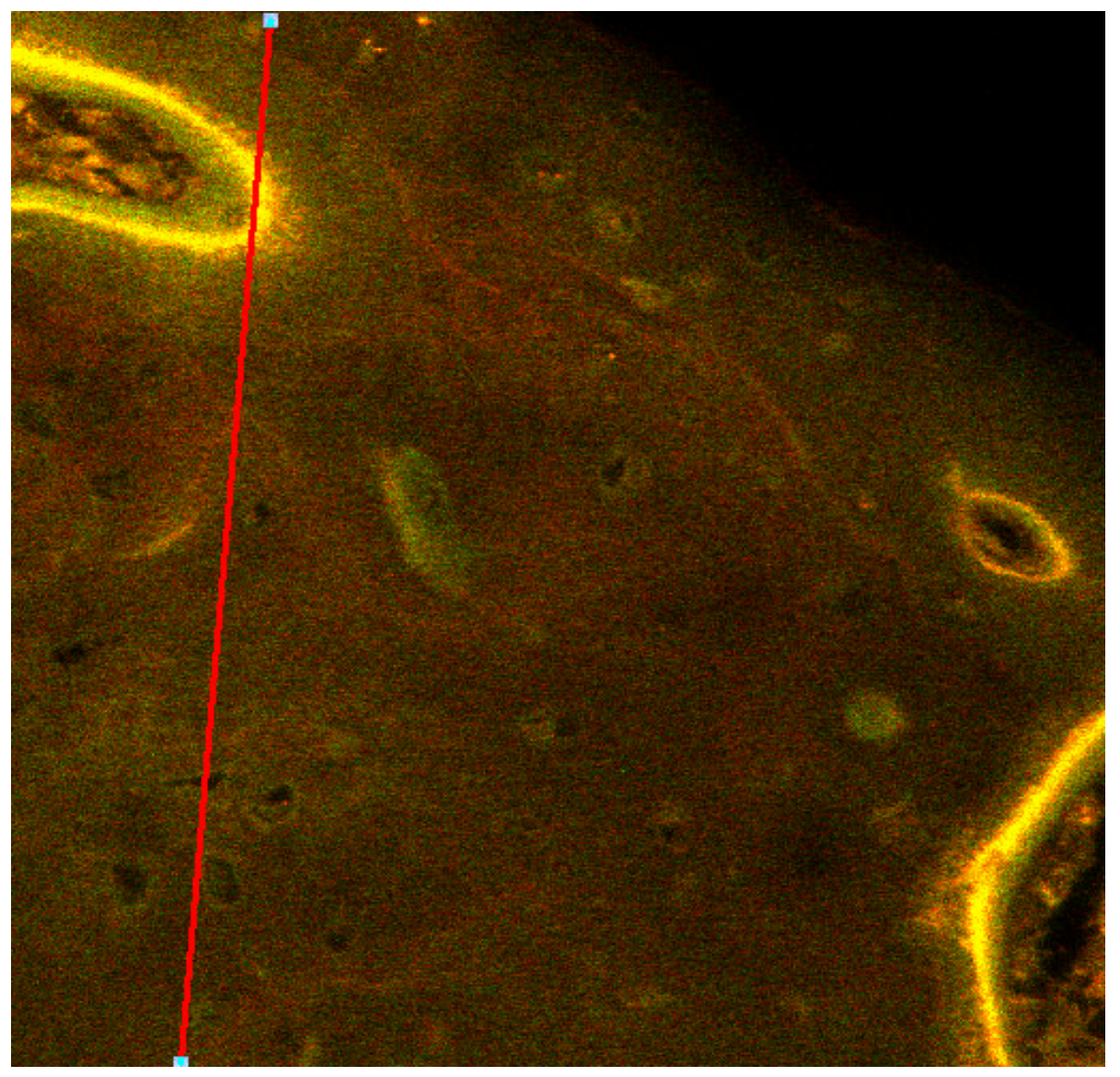

FIGURA 33 -Imagem obtida da região medular, lâmina 5 e respectiva $R O$ em aumento de 40 vezes 


\section{Lâmina 6 (observações gerais):}

De modo geral, o padrão observado na lâmina 6 é semelhante à lâmina 5, observando-se entretanto, a presença de maior volume ósseo nas áreas correspondentes às corticais superior e inferior. Nas roscas 1 e 2 não se visualiza a presença dos marcadores em alta intensidade, podendo se observar extensa área fracamente corada com CAL e TTC, sem AL, com exceção de pequena área marcada em contato direto com a superfície do metal (Figura 34). Em maior aumento, observa-se nesta região extensas áreas marcadas externamente com TCC e internamente com CAL, sem observar-se a presença de AL, com exceção da pequena área anteriormente descrita (Figura 35). Nas roscas 3 e 4, nota-se uma pequena faixa corada com AL em contato direto com a superfície do metal. As paredes dos vasos sangüíneos são coradas com TTC e CAL, indicando diminuição de sua luz em função do crescimento ósseo (Figura 36). Em maior aumento, observa-se nesta região extensa área marcada externamente por TTC (amarelo) e internamente por CAL (verde), próximo à superfície do metal. Em outra região, nota-se a presença de $A L$, em vermelho (Figura 37). Novamente em menor aumento, observa-se a presença de CAL e TTC, mais afastada da superfície do metal, embora esta última não esteja bem característica (Figura 38). Em maior aumento, especialmente para a rosca 6 , não se observa a presença de nenhum dos marcadores utilizados (Figura 39). 


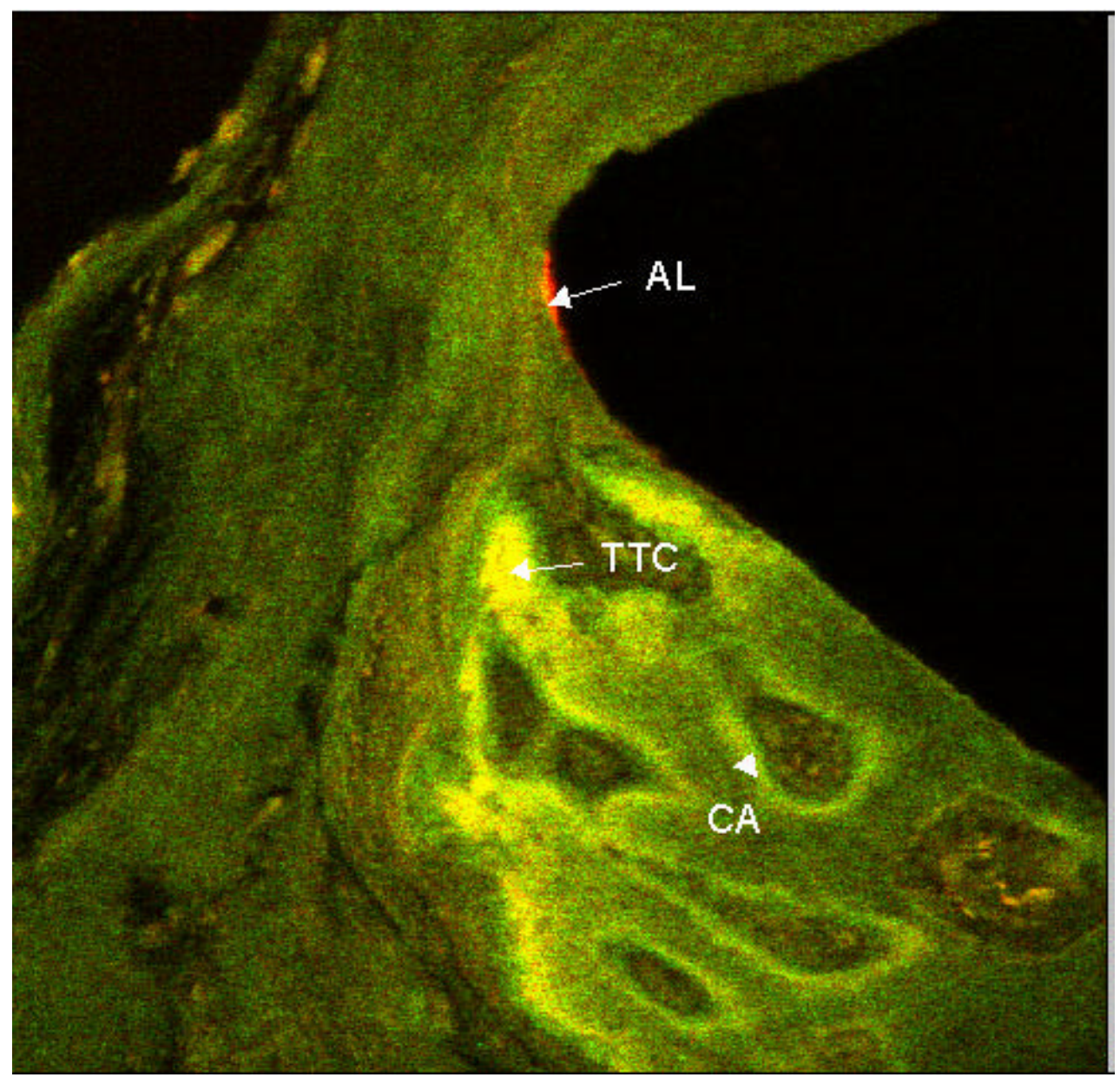

FIGURA 34 - Imagem obtida da região cortical (roscas 1 e 2) da lâmina 6 


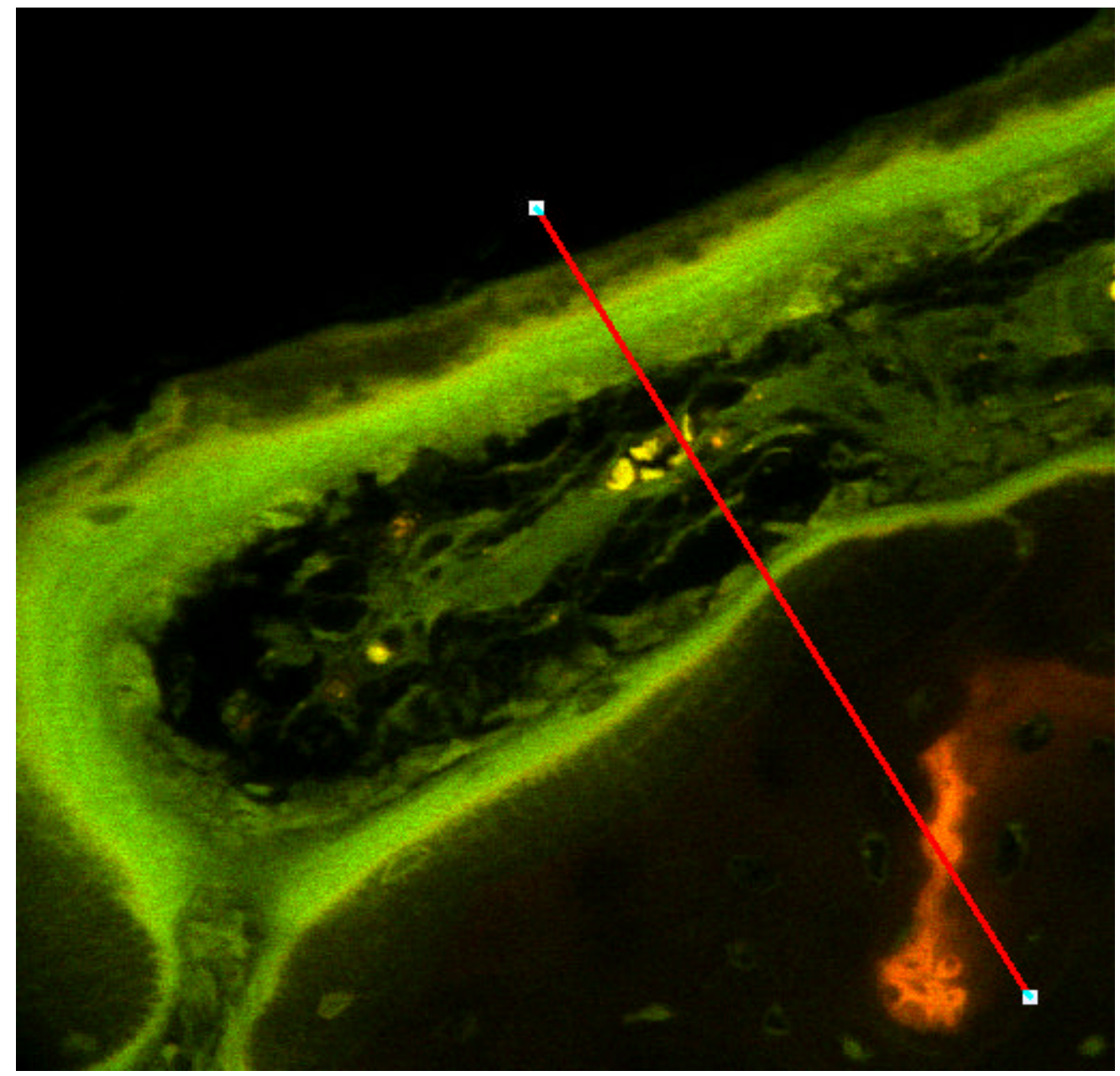

FIGURA 35-Imagem obtida da região cortical, lâmina 6, e respectiva $R O I$ em aumento de 40 vezes 


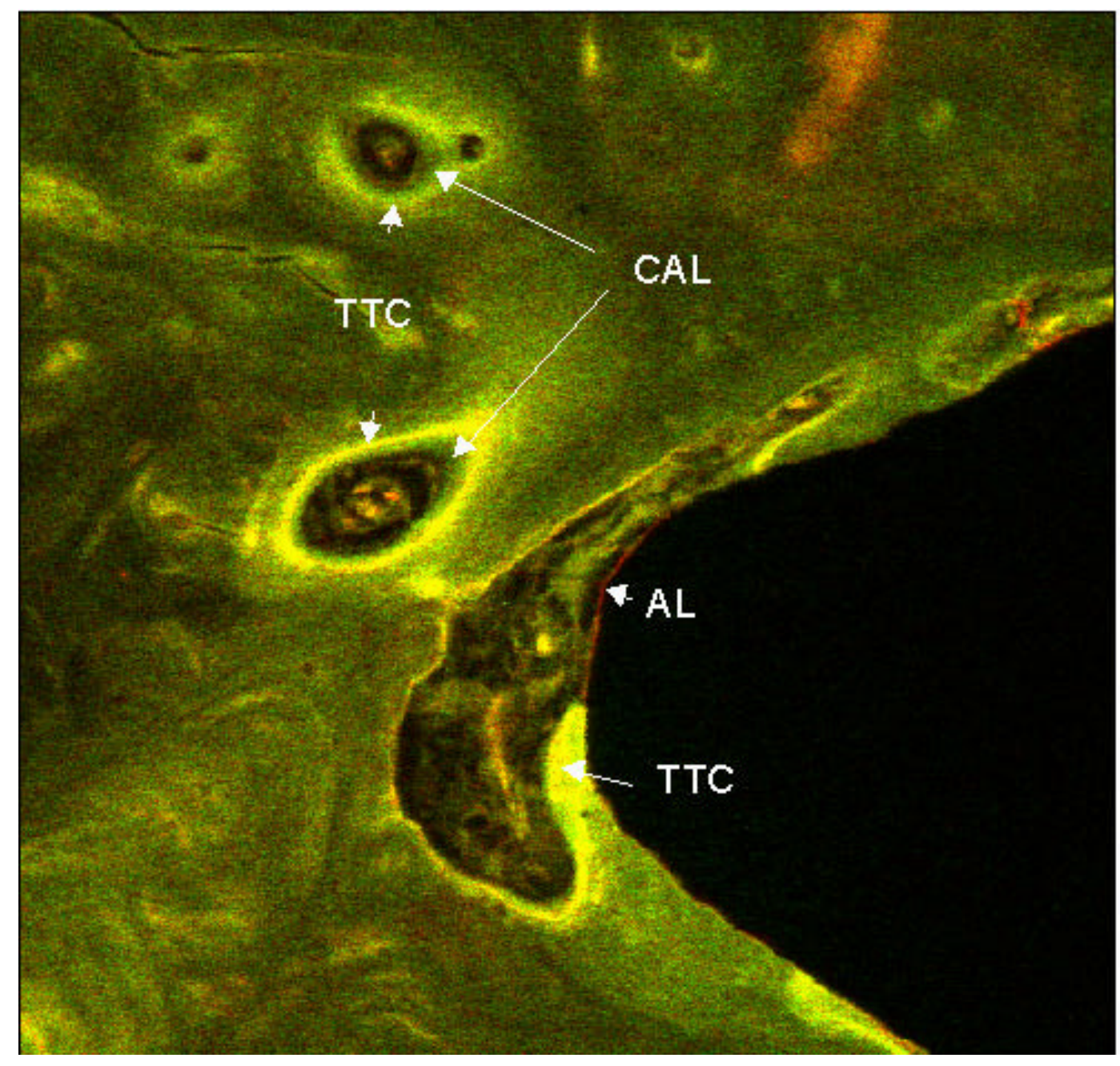

FIGURA 36 - Imagem obtida da região sub-cortical (roscas 3 e 4) da lâmina 6 


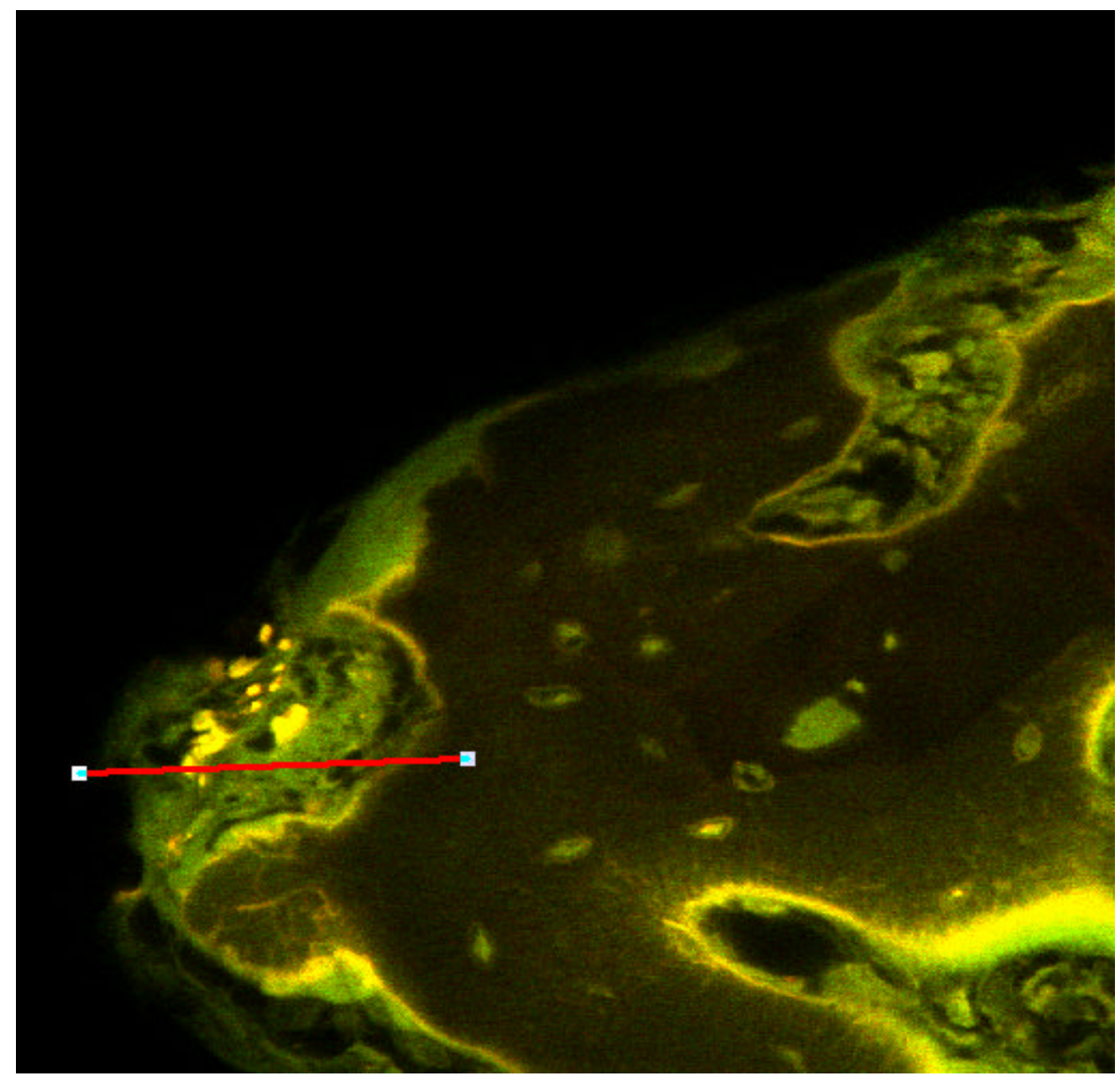

FIGURA 37 - Imagem obtida da região sub-cortical, lâmina 6, e respectiva $R O$ em aumento de 40 vezes 


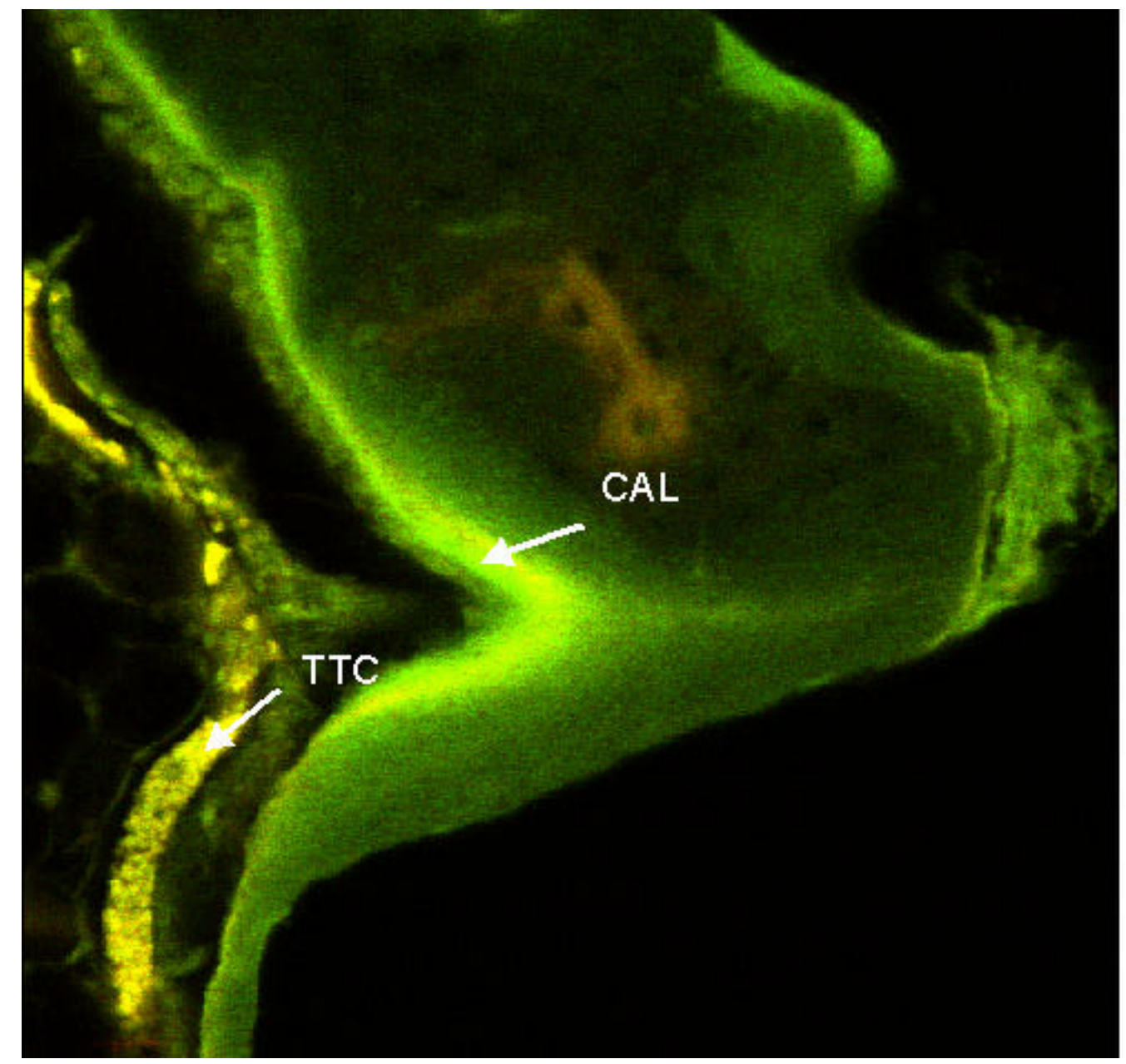

FIGURA 38 - Imagem obtida da região medular (roscas 5 e 6) da lâmina 6 


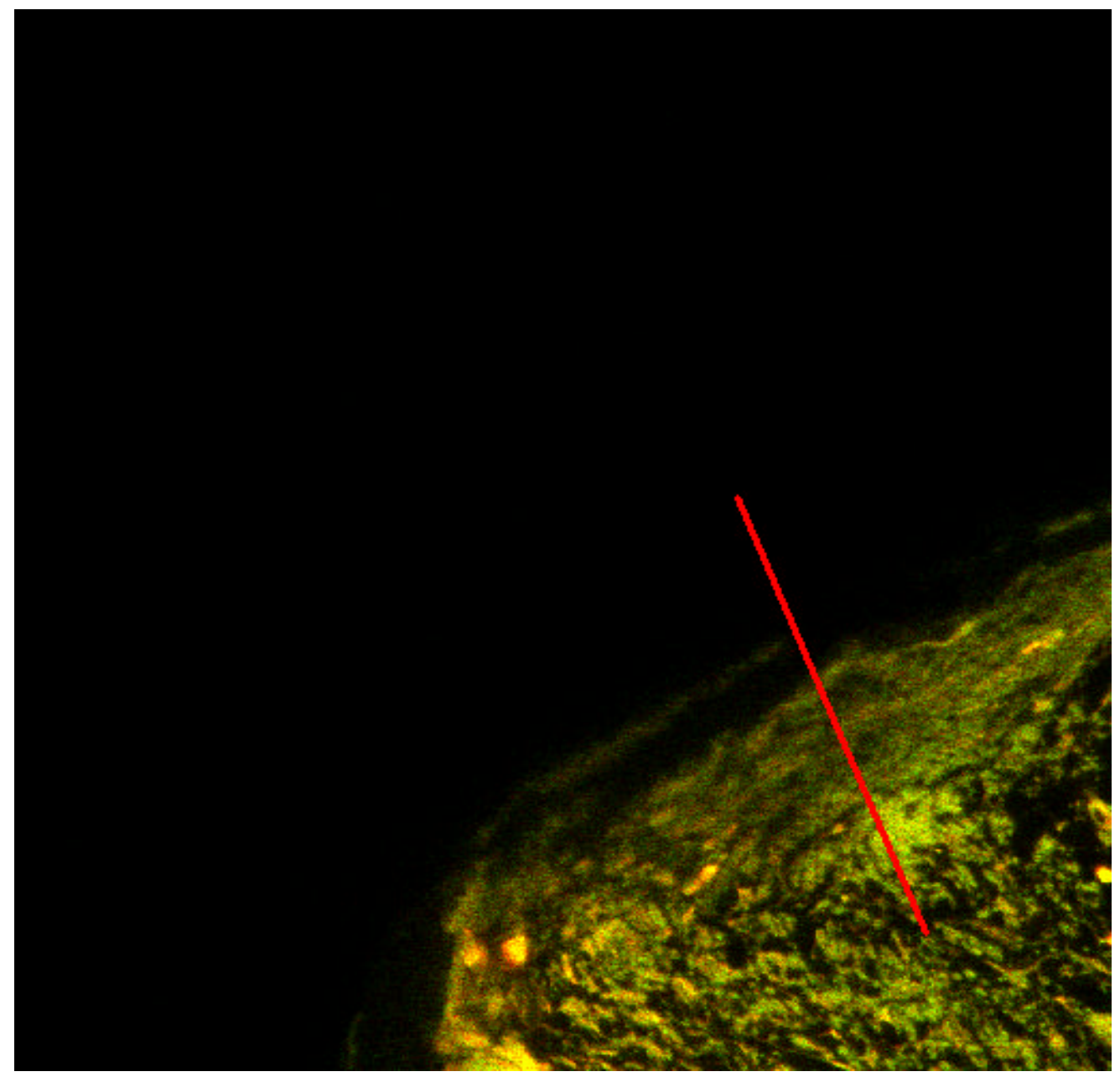

FIGURA 39 -Imagem obtida da região medular, lâmina 6 , e respectivo $R O$ em aumento de 40 vezes 


\section{ANÁLISE DO PERFIL DA LÂMINA 1}

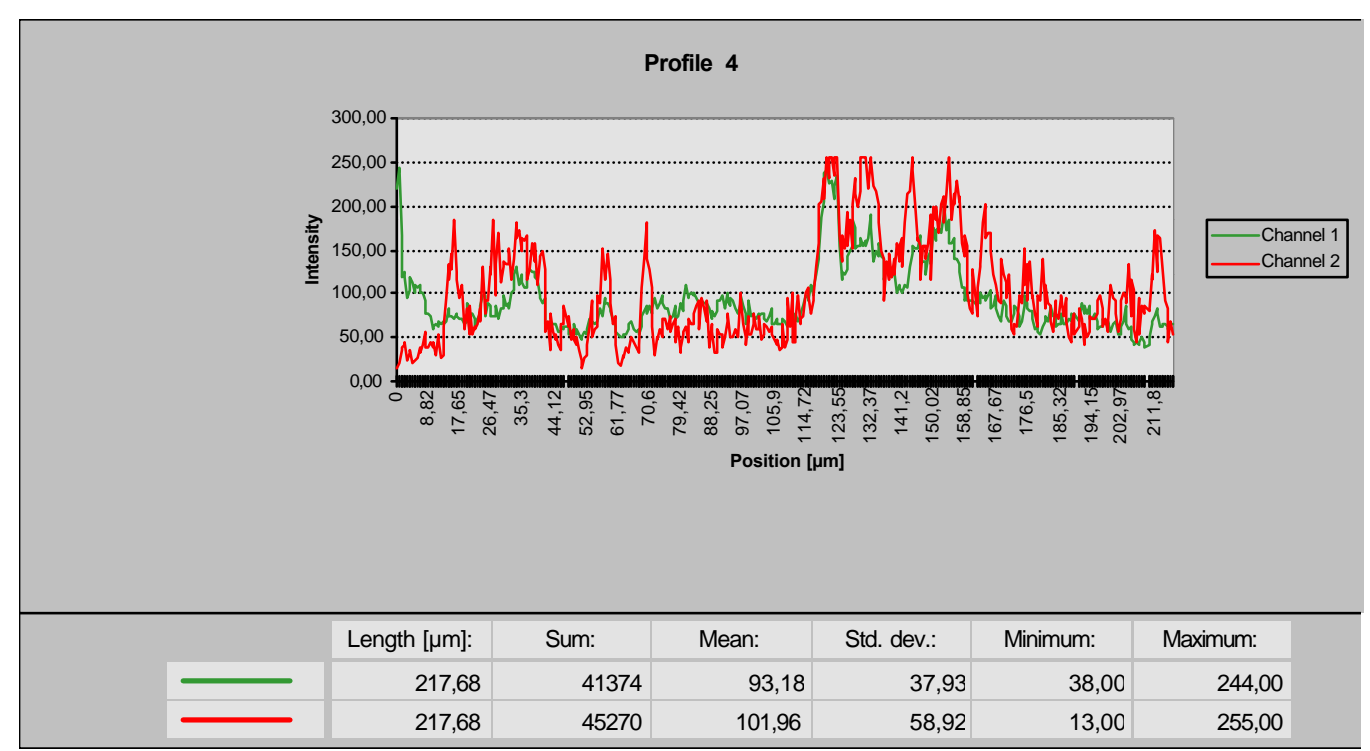

FIGURA 40 - Região cortical

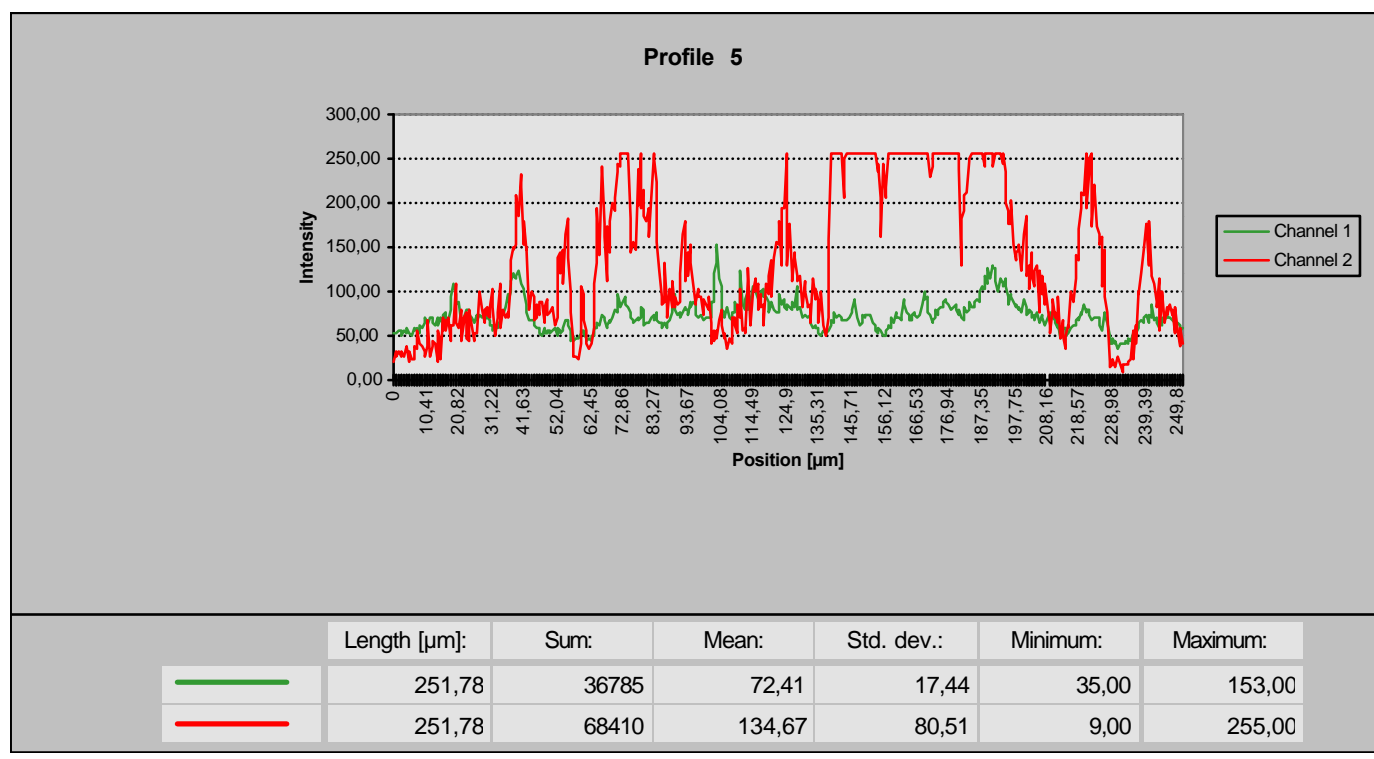

FIGURA 41 - Região sub-cortical 


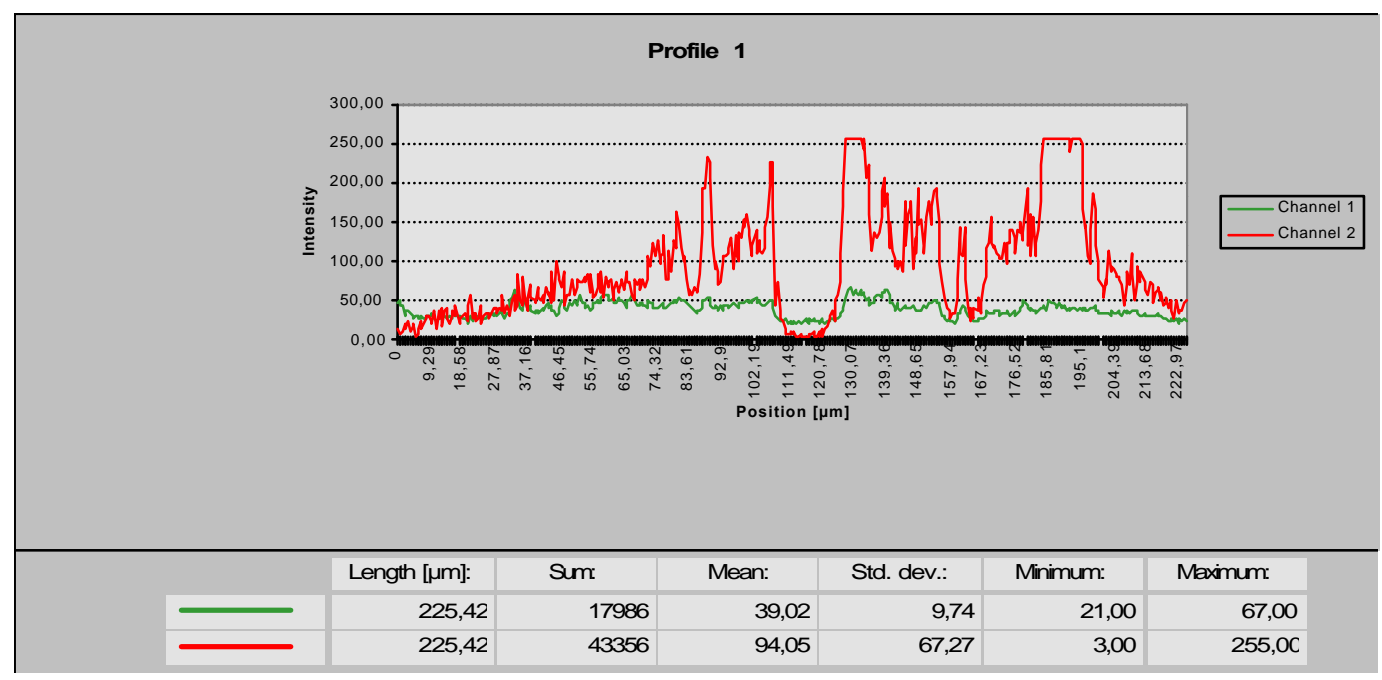

FIGURA 42 - Região medular

ANÁLISE DO PERFIL DA LÂMINA 3

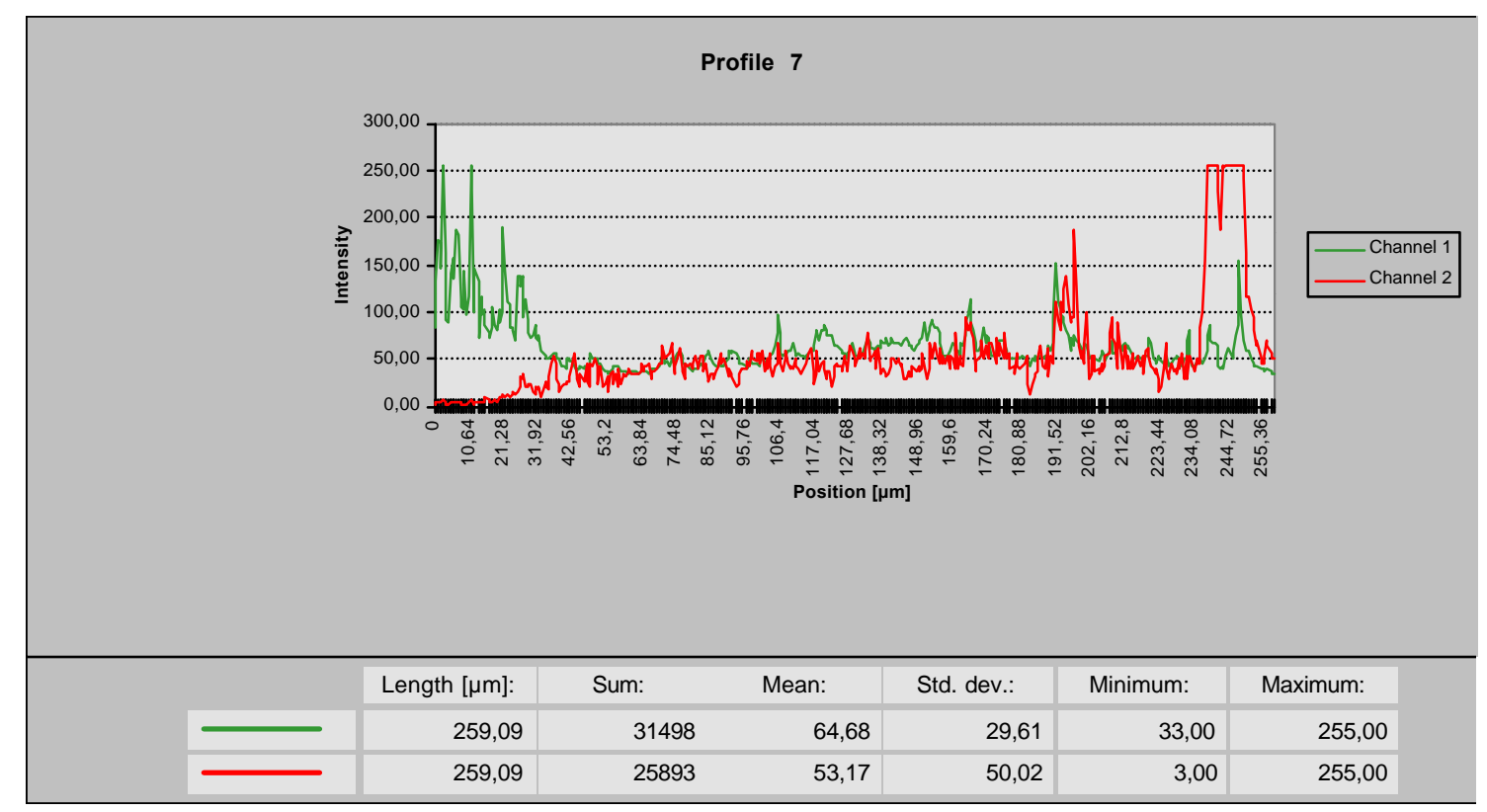




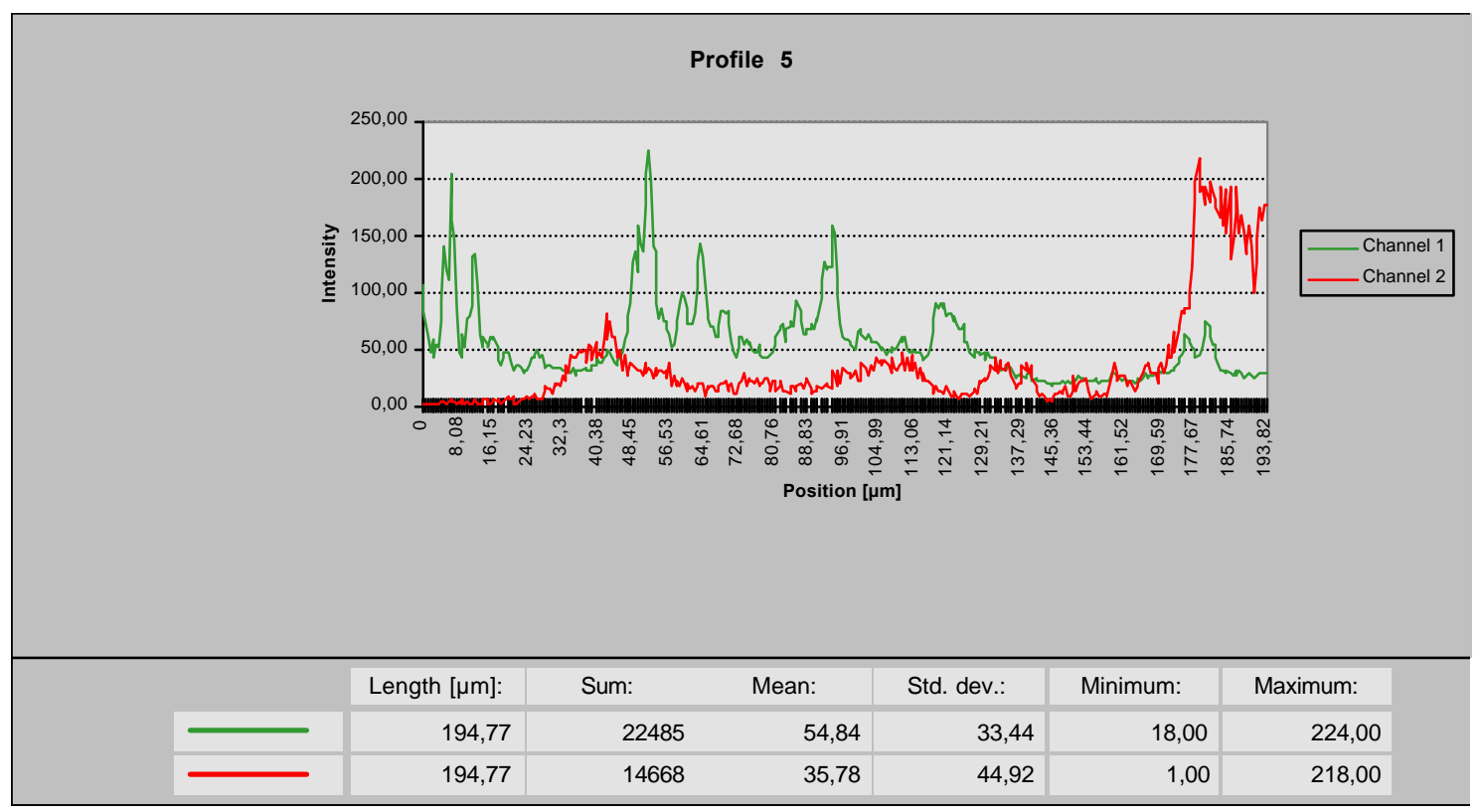

FIGURA 44 - Região sub-cortical

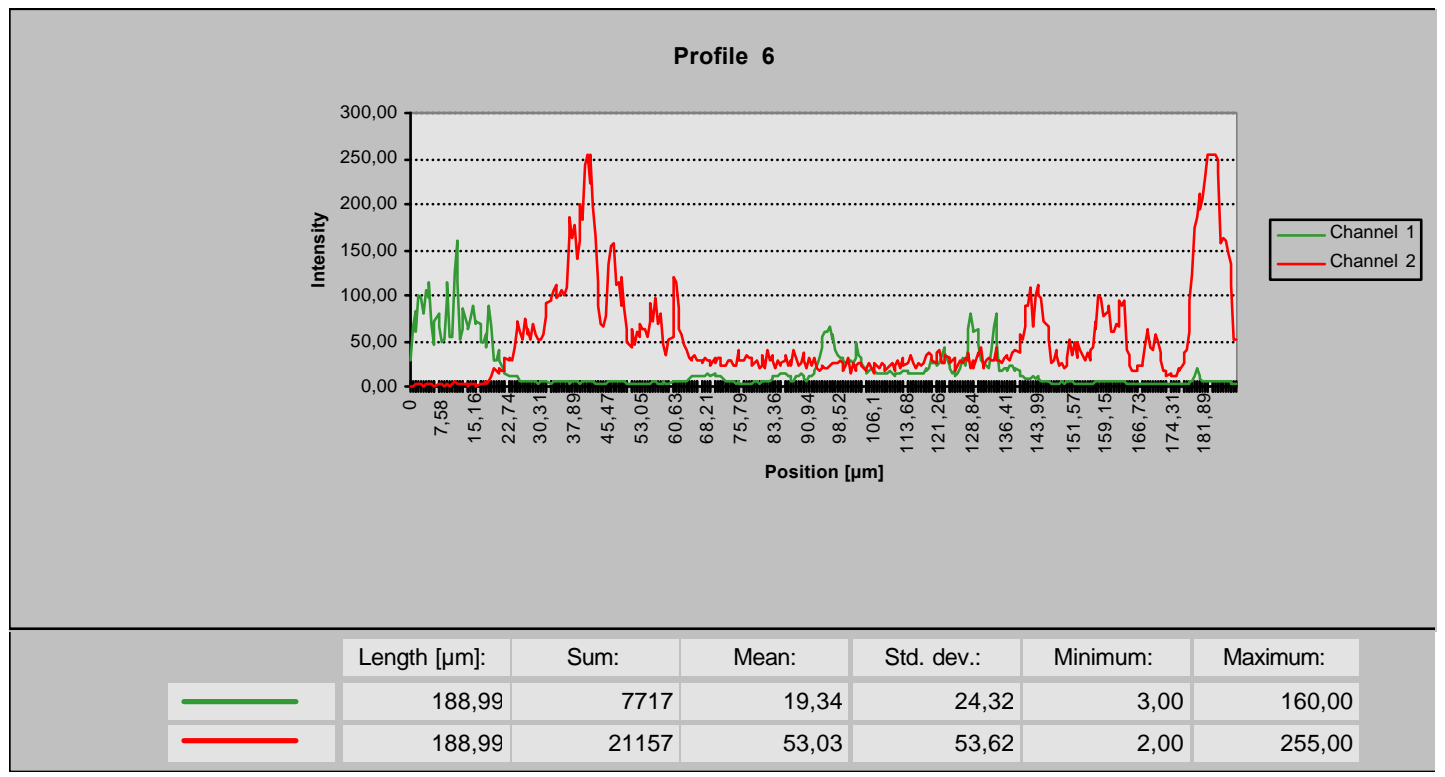

FIGURA 45 - Região medular 


\section{ANÁLISE DO PERFIL DA LÂMINA 4}

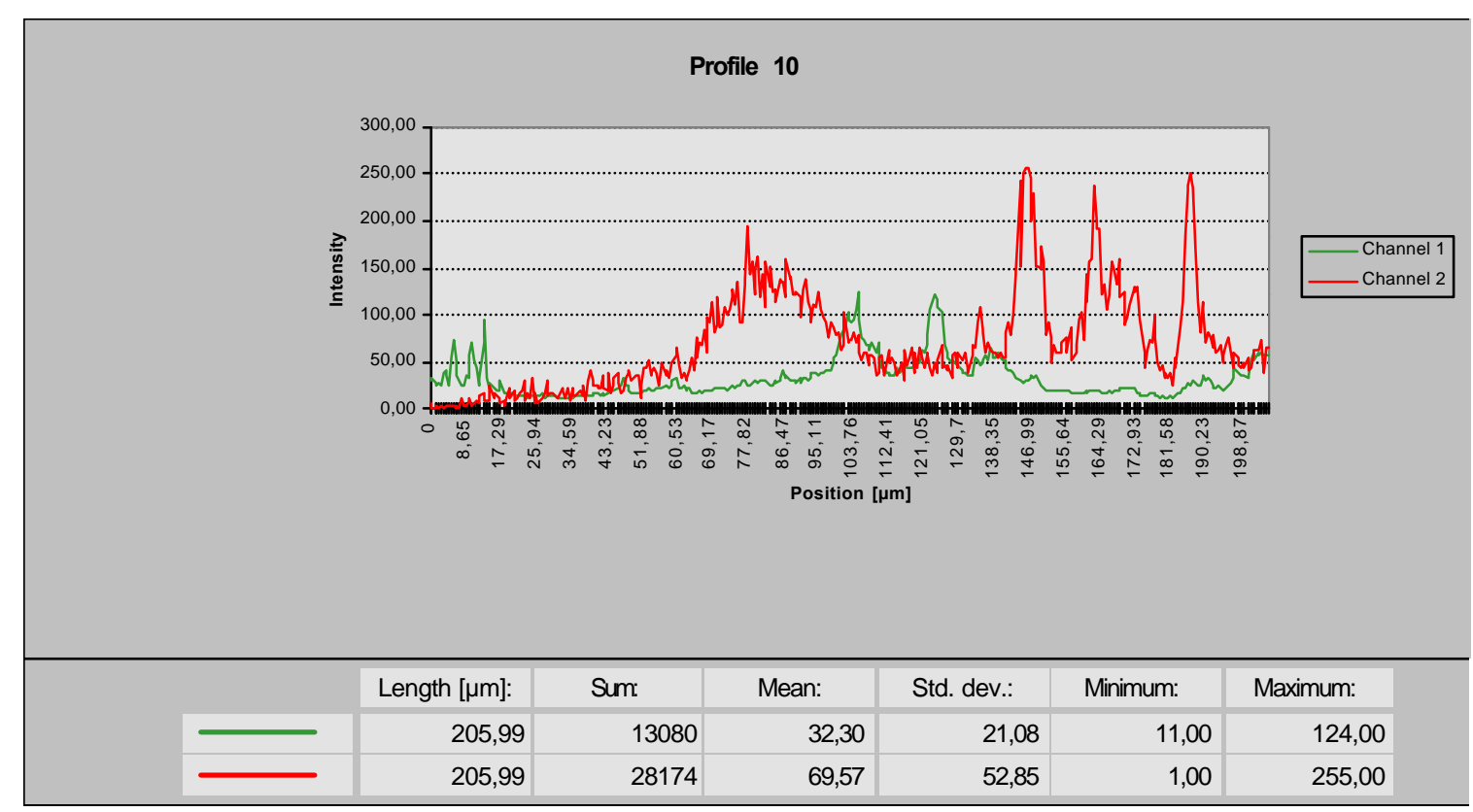

FIGURA 46 - Região cortical

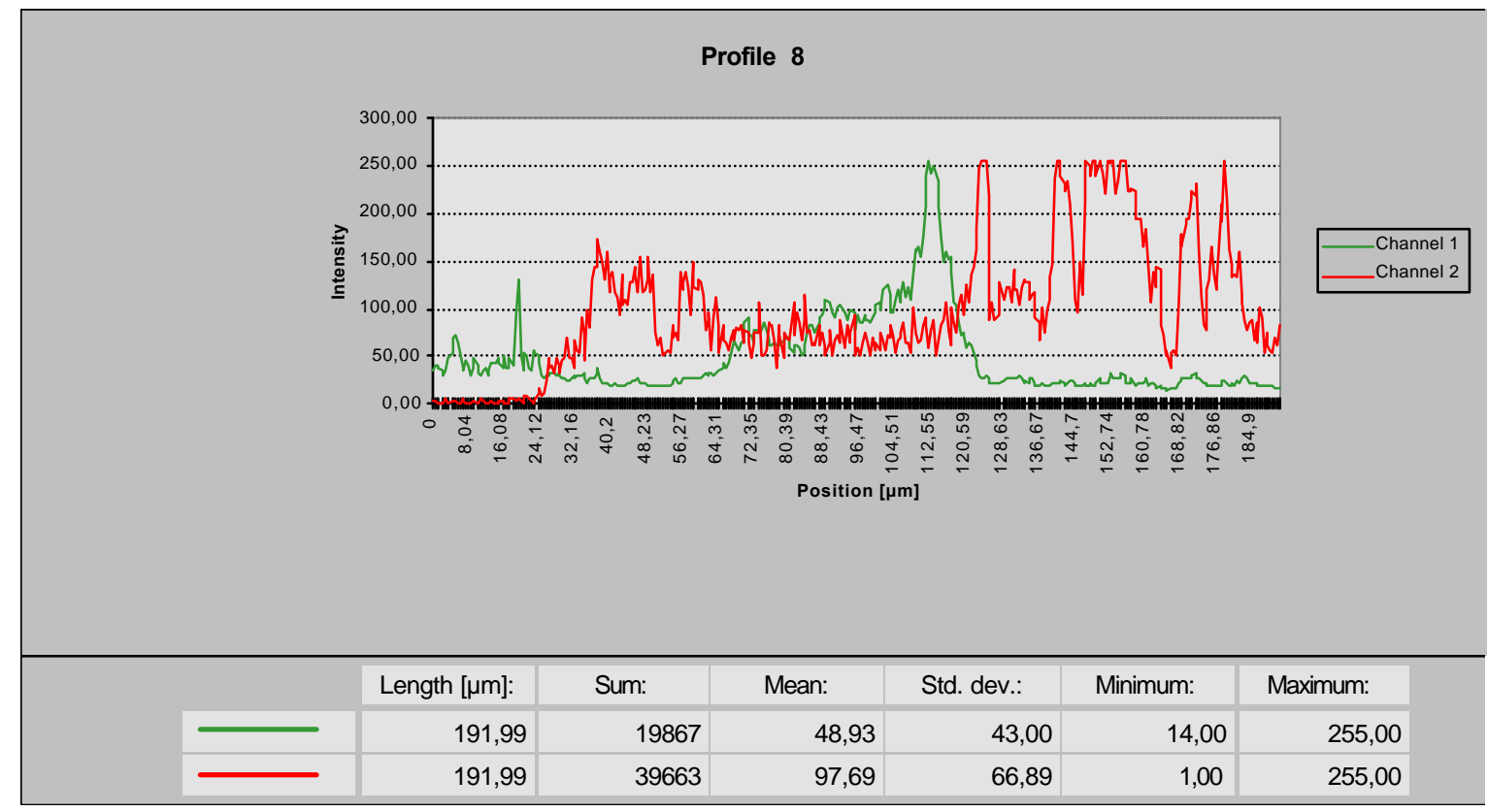

FIGURA 47 - Região sub-cortical 


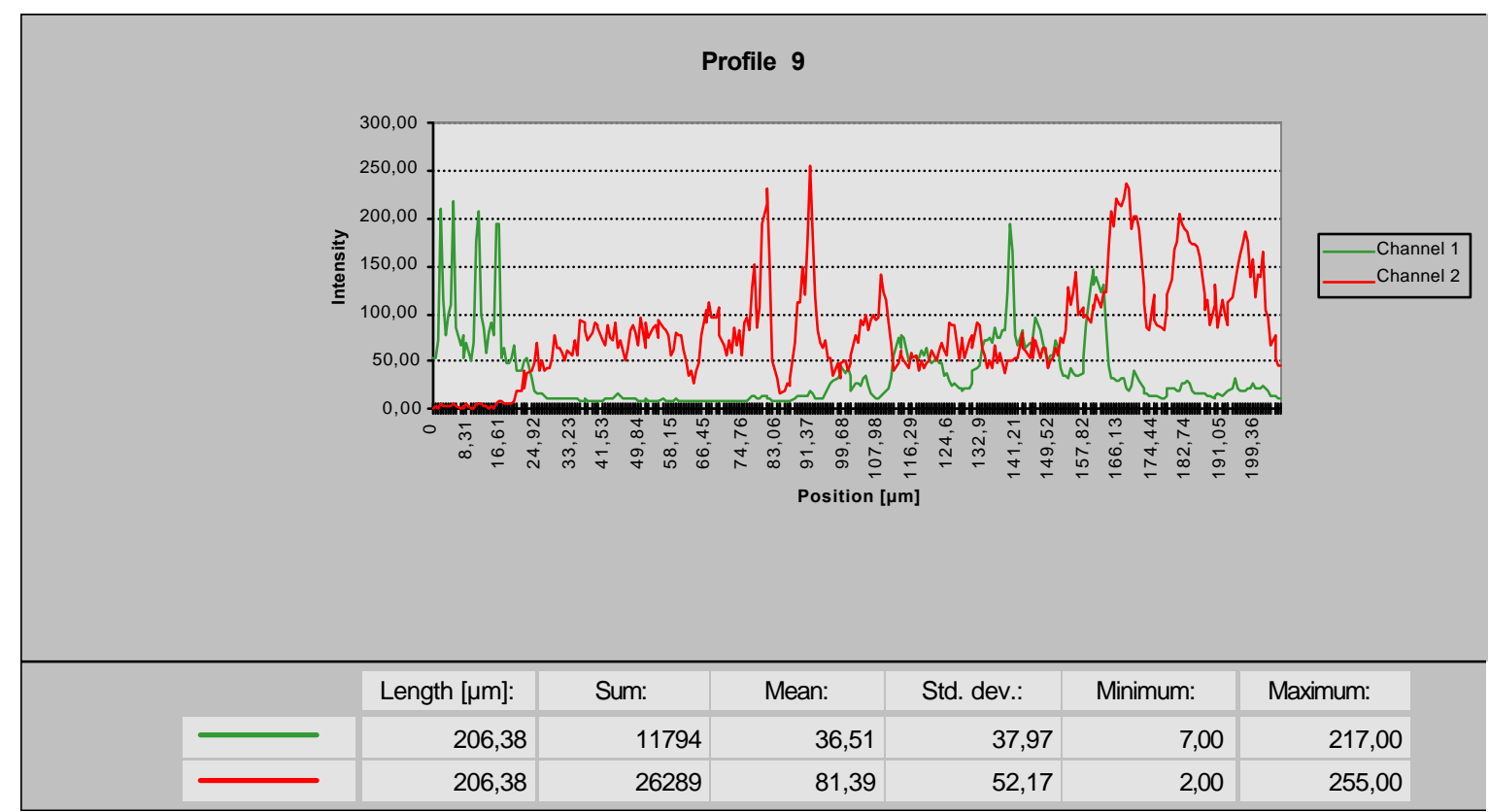

FIGURA 48 - Região medular

ANÁLISE DO PERFIL DA LÂMINA 5

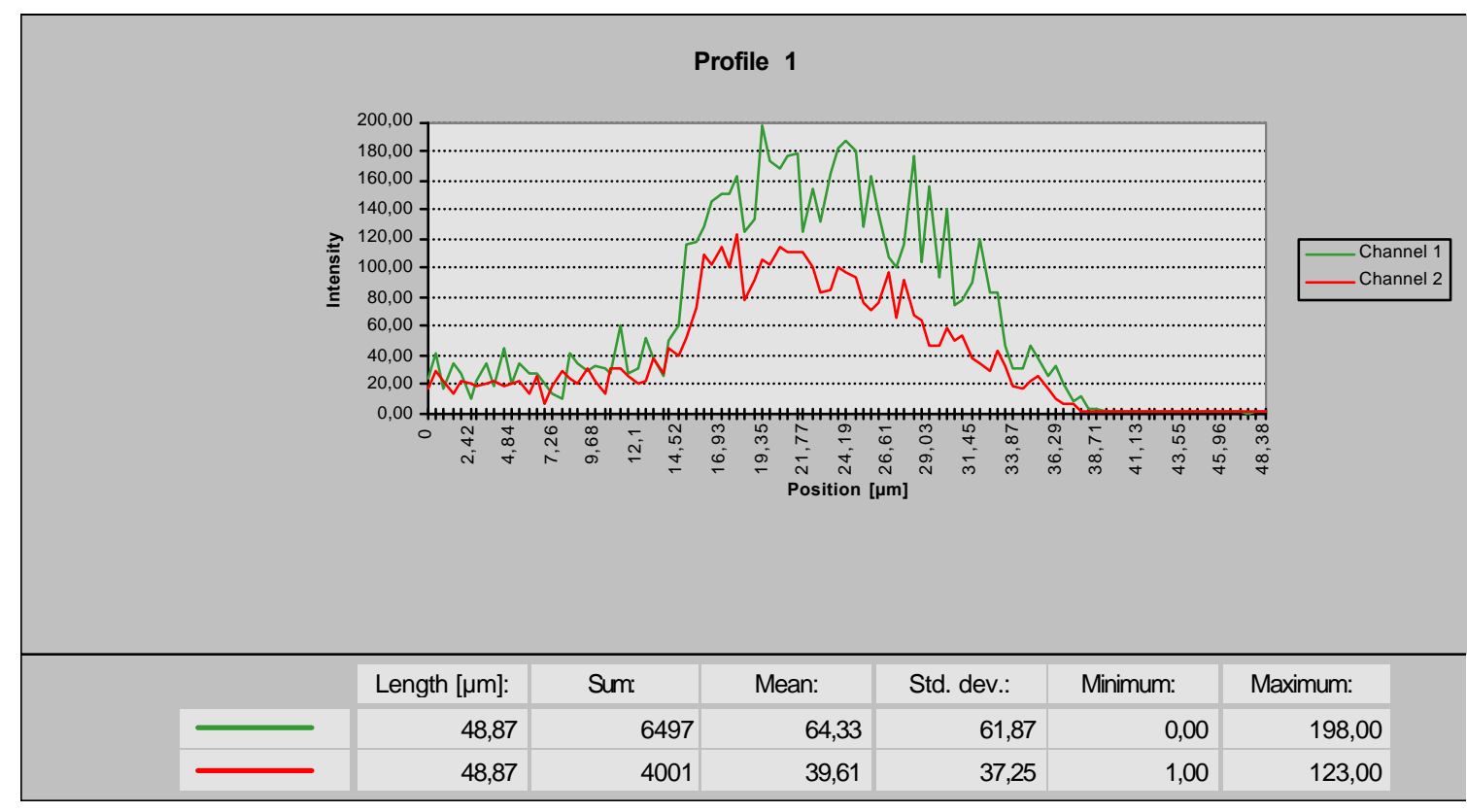

FIGURA 49 - Região cortical 


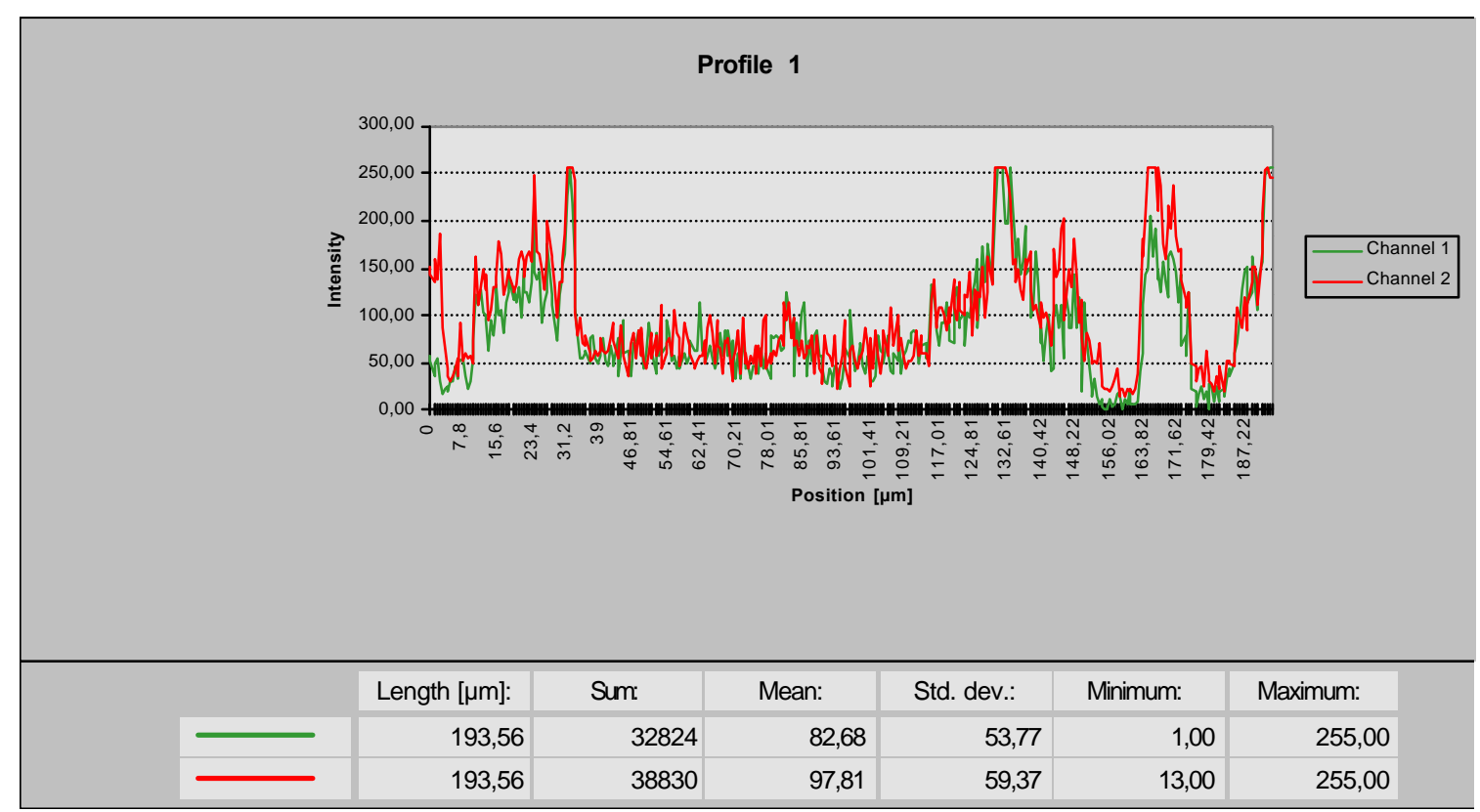

FIGURA 50 - Região sub-cortical

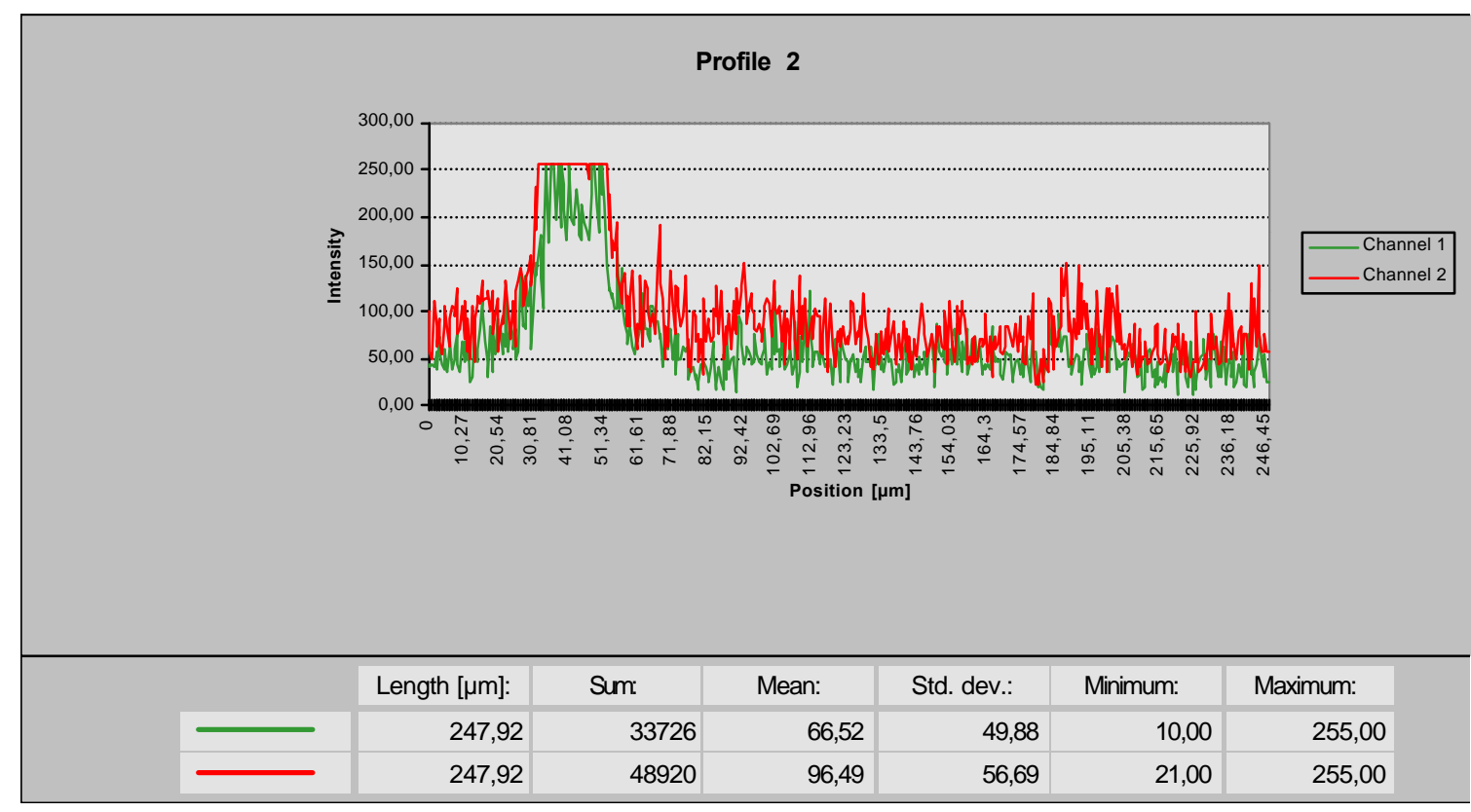

FIGURA 51 - Região medular 


\section{ANÁLISE DO PERFIL DA LÂMINA 6}

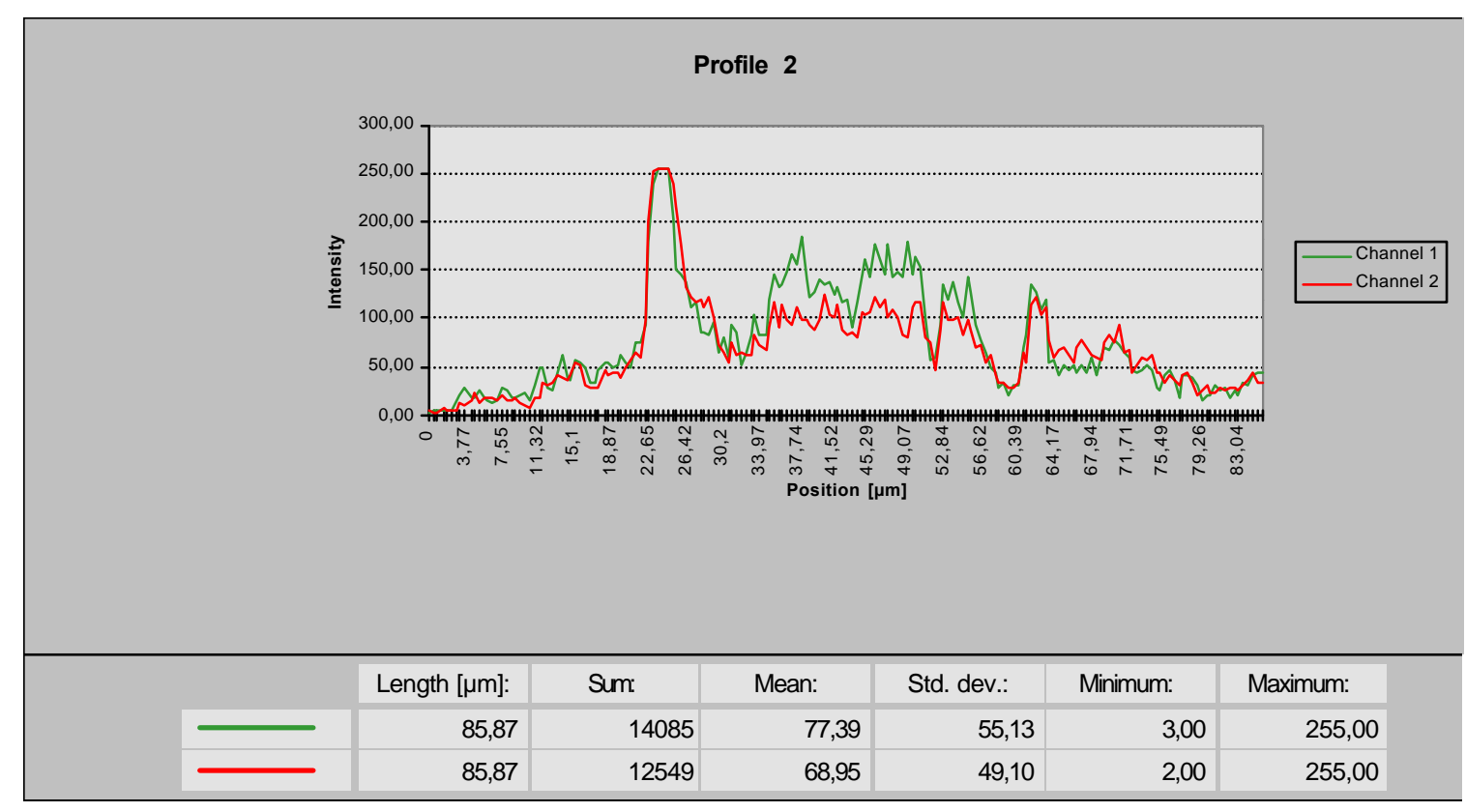

FIGURA 52 - Região cortical

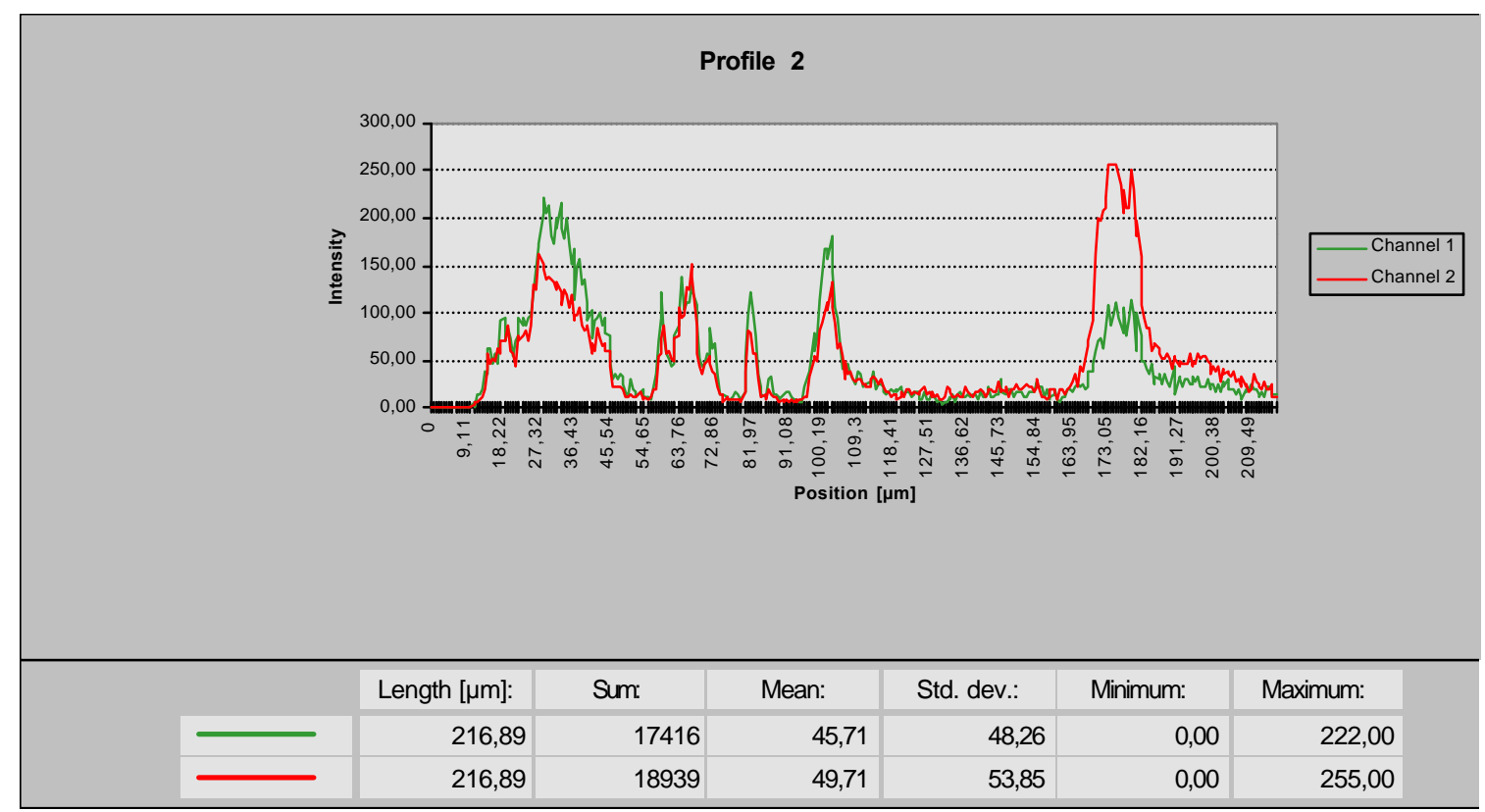

FIGURA 53 - Região sub-cortical 


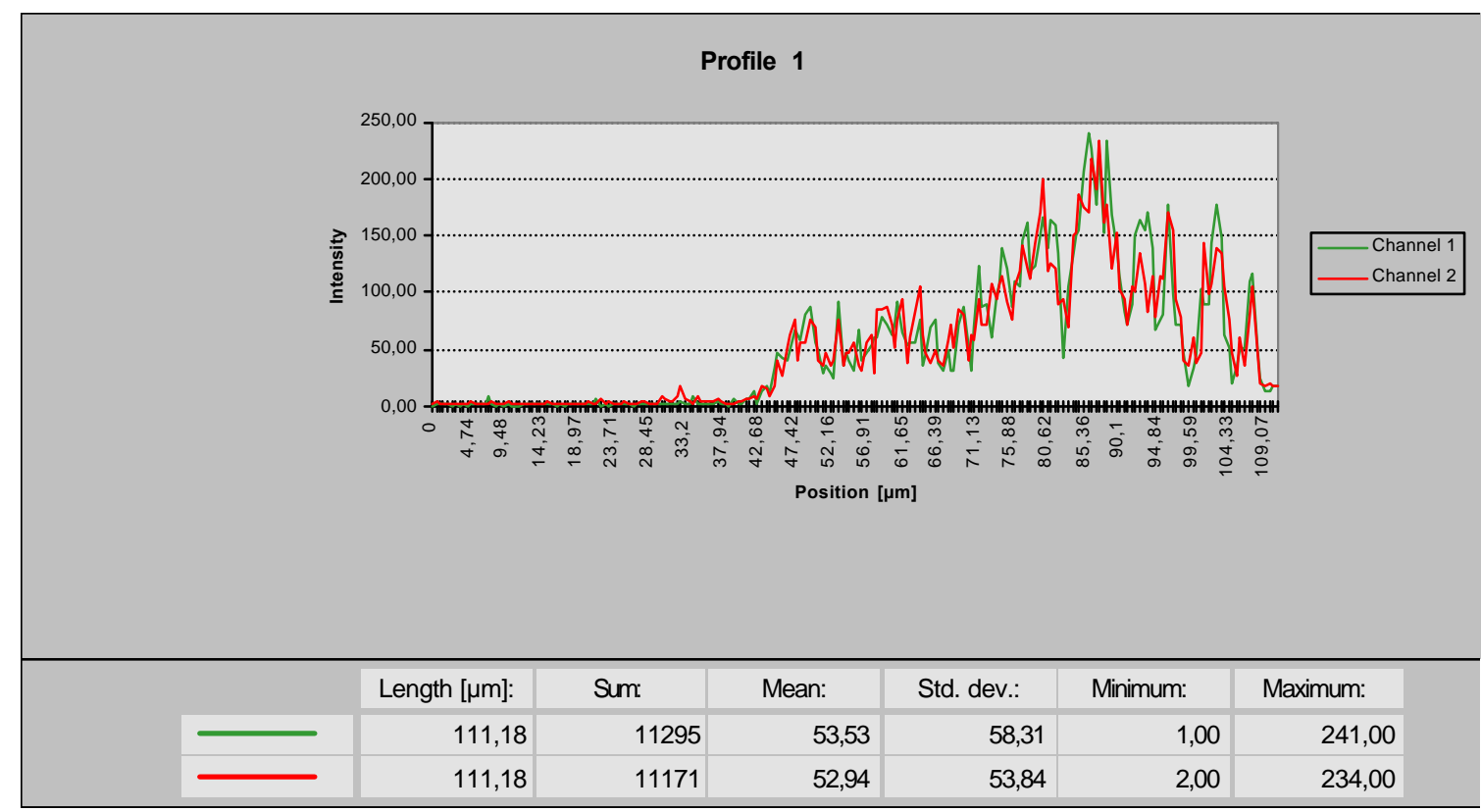

FIGURA 54 - Região medular

HISTOGRAMA DA LÂMINA 1

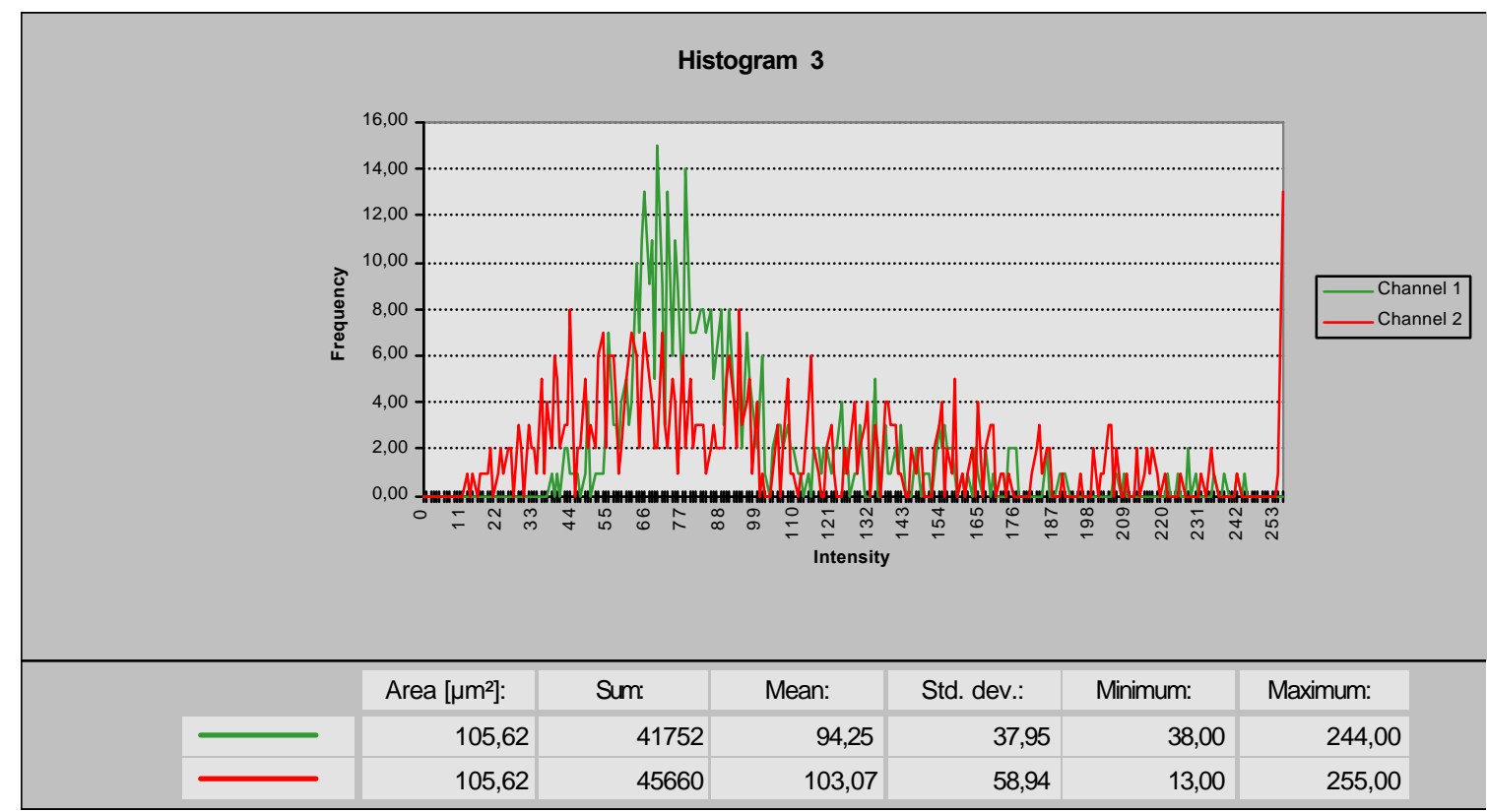

FIGURA 55 - Região cortical 


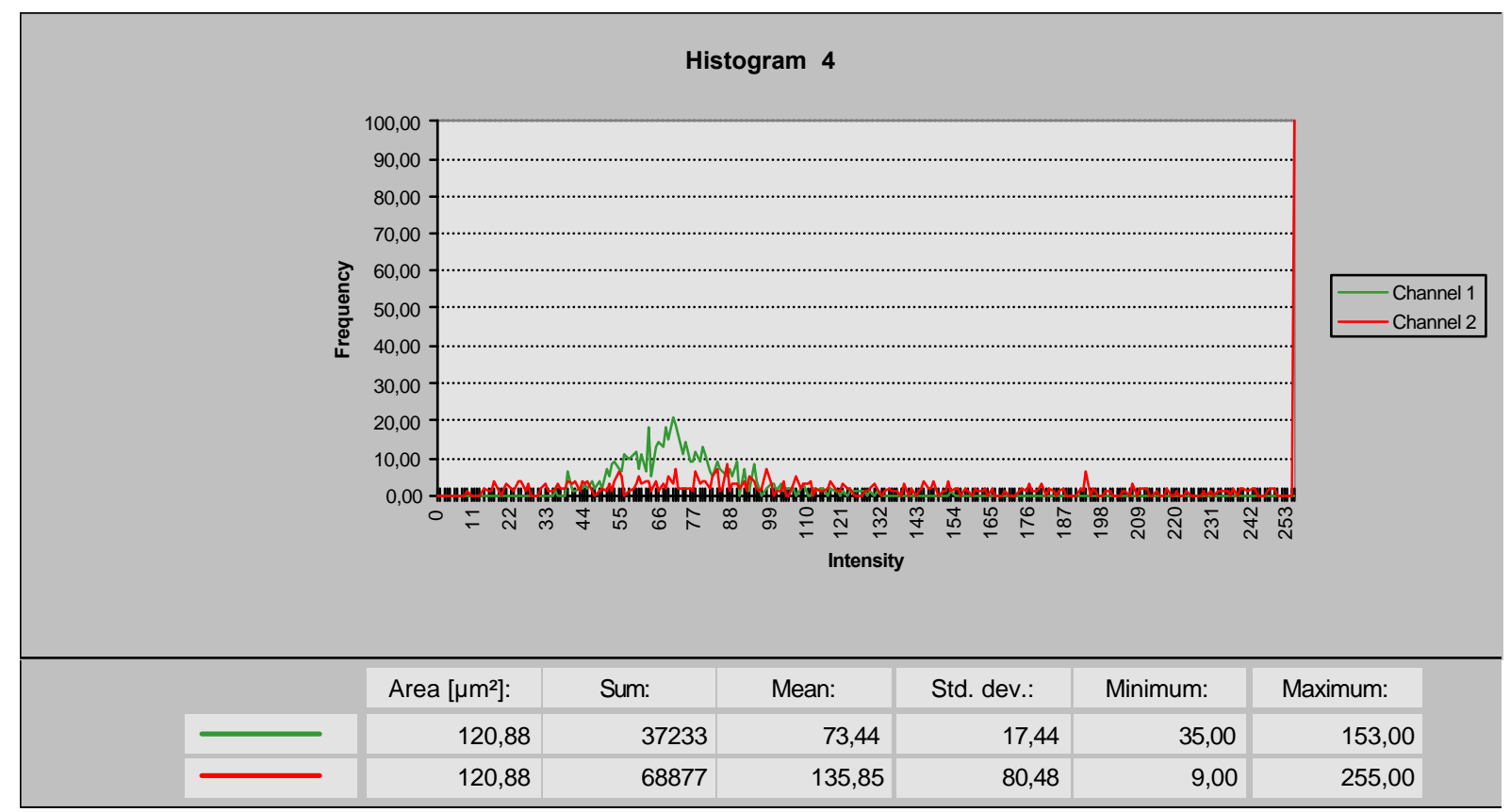

FIGURA 56 - Região sub-cortical

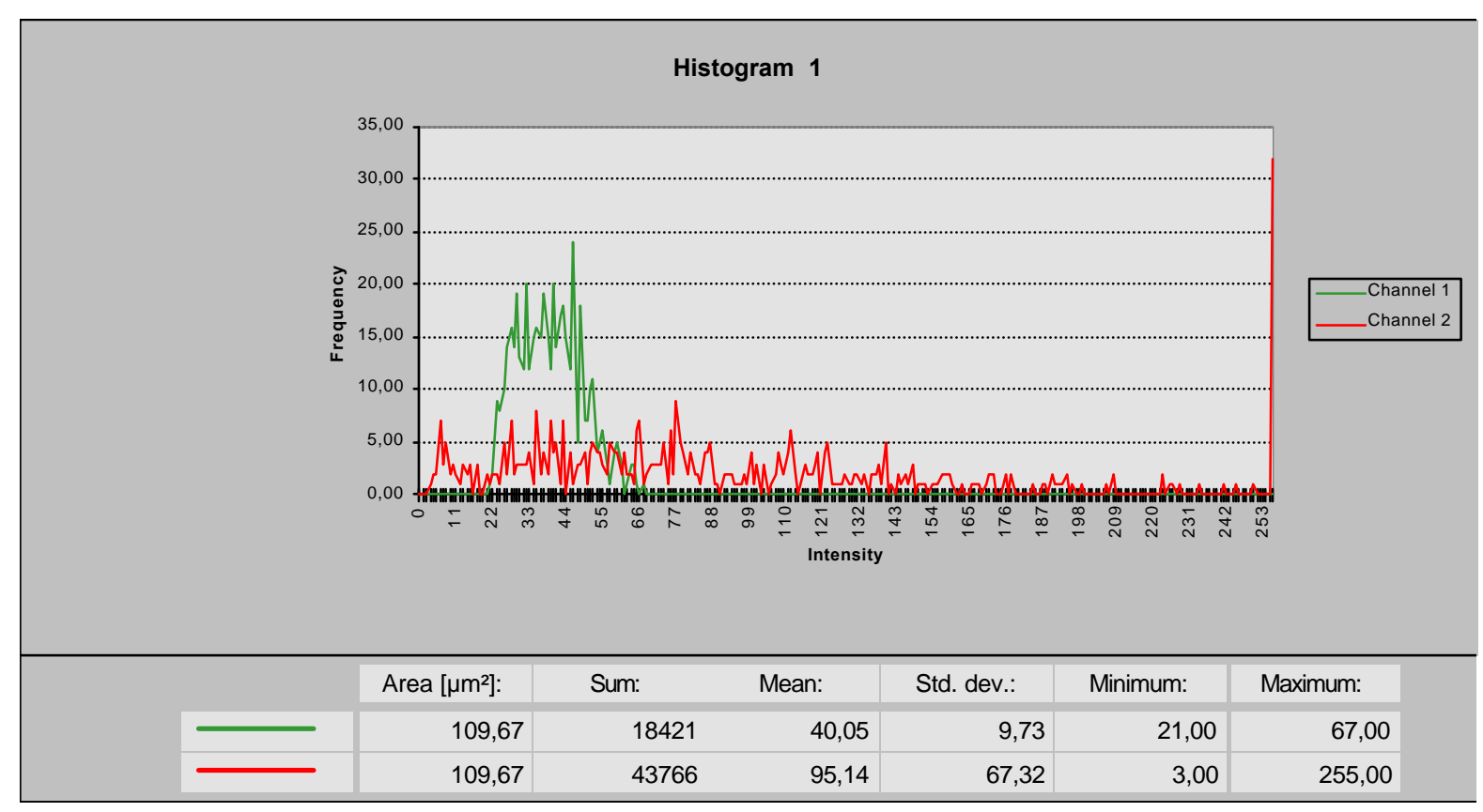

FIGURA 57 - Região medular 
HISTOGRAMA DA LÂMINA 3

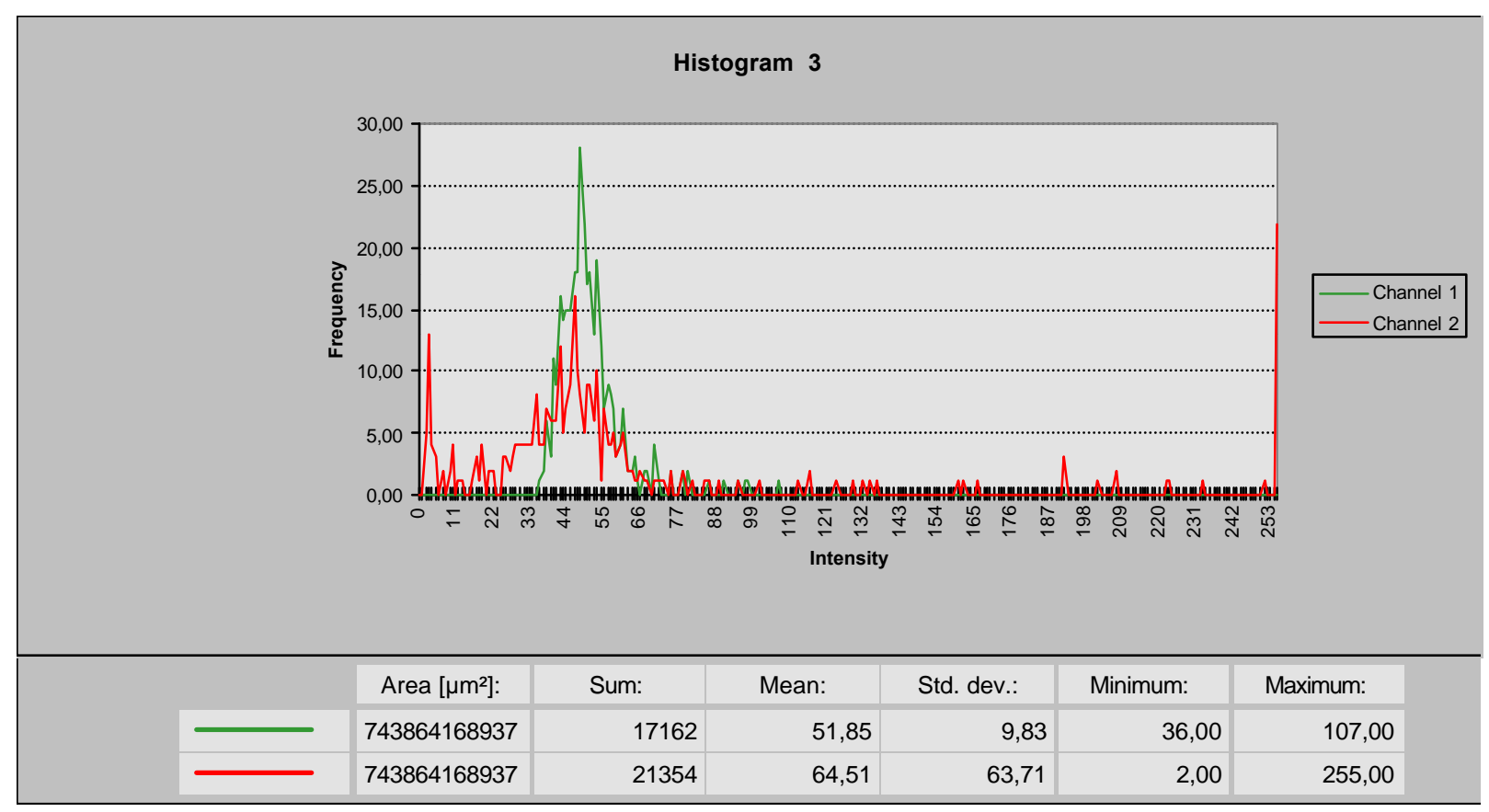

FIGURA 58 - Região cortical

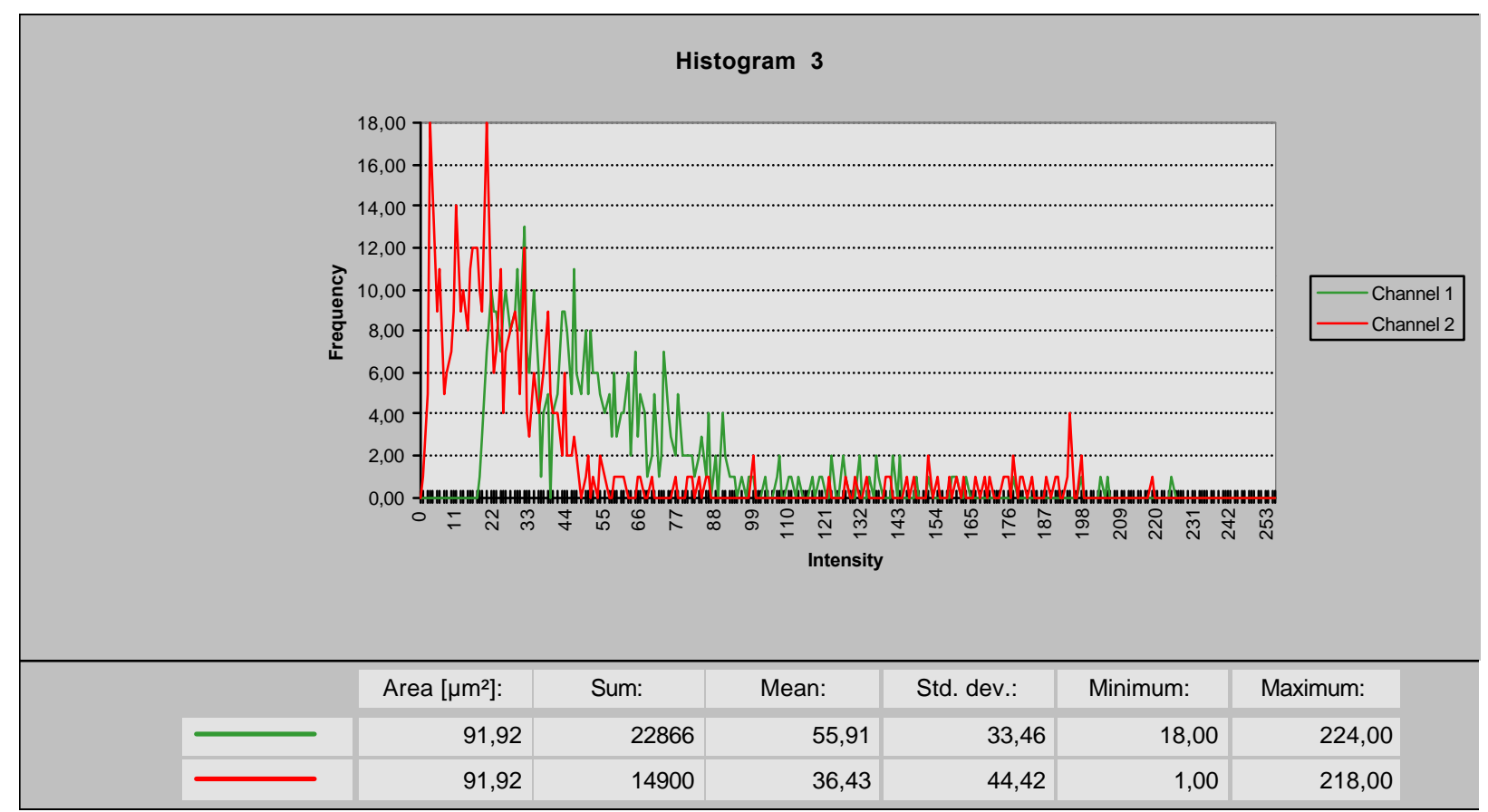




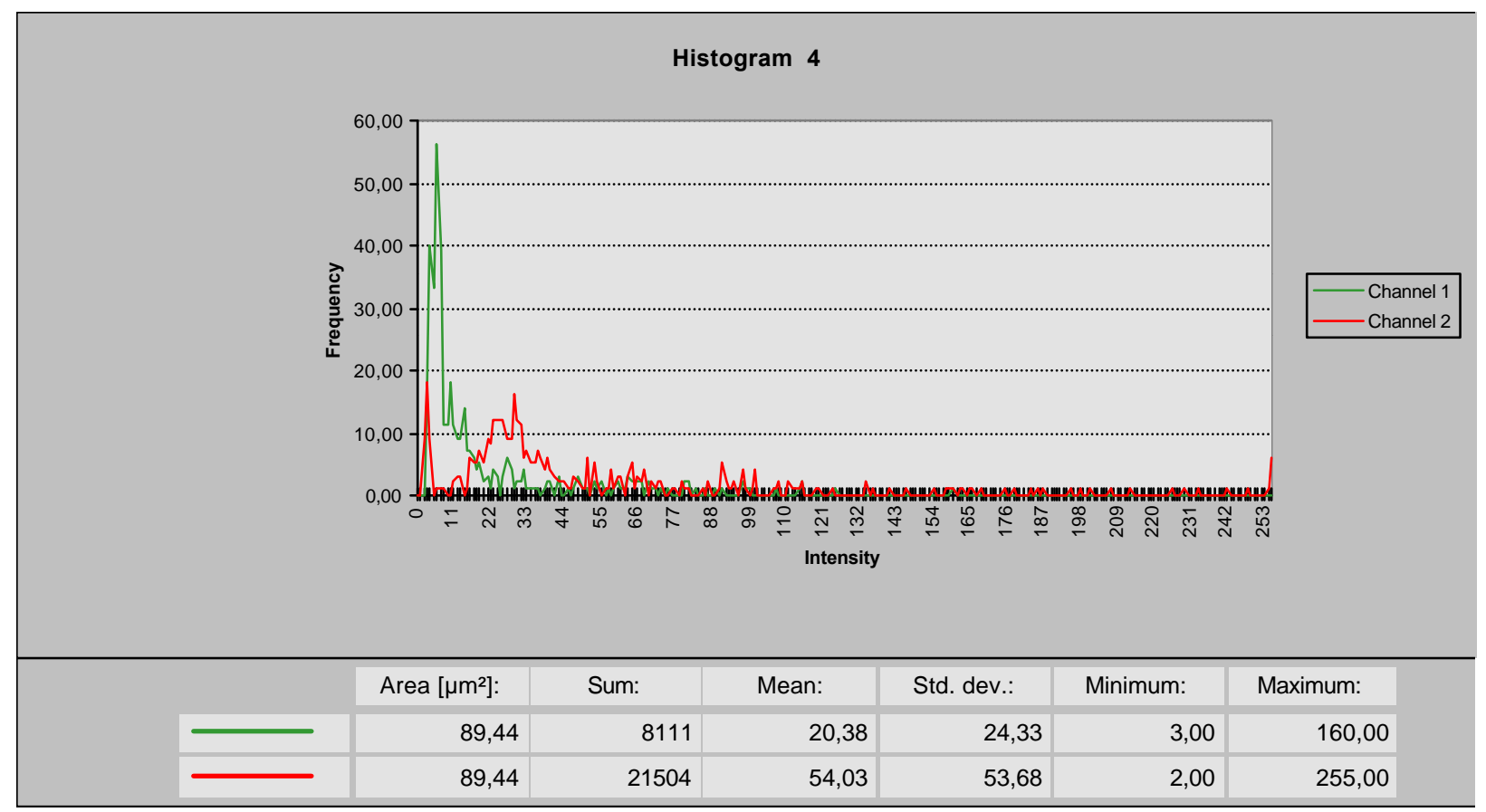

FIGURA 60 - Região medular

\section{HISTOGRAMA DA LÂMINA 4}

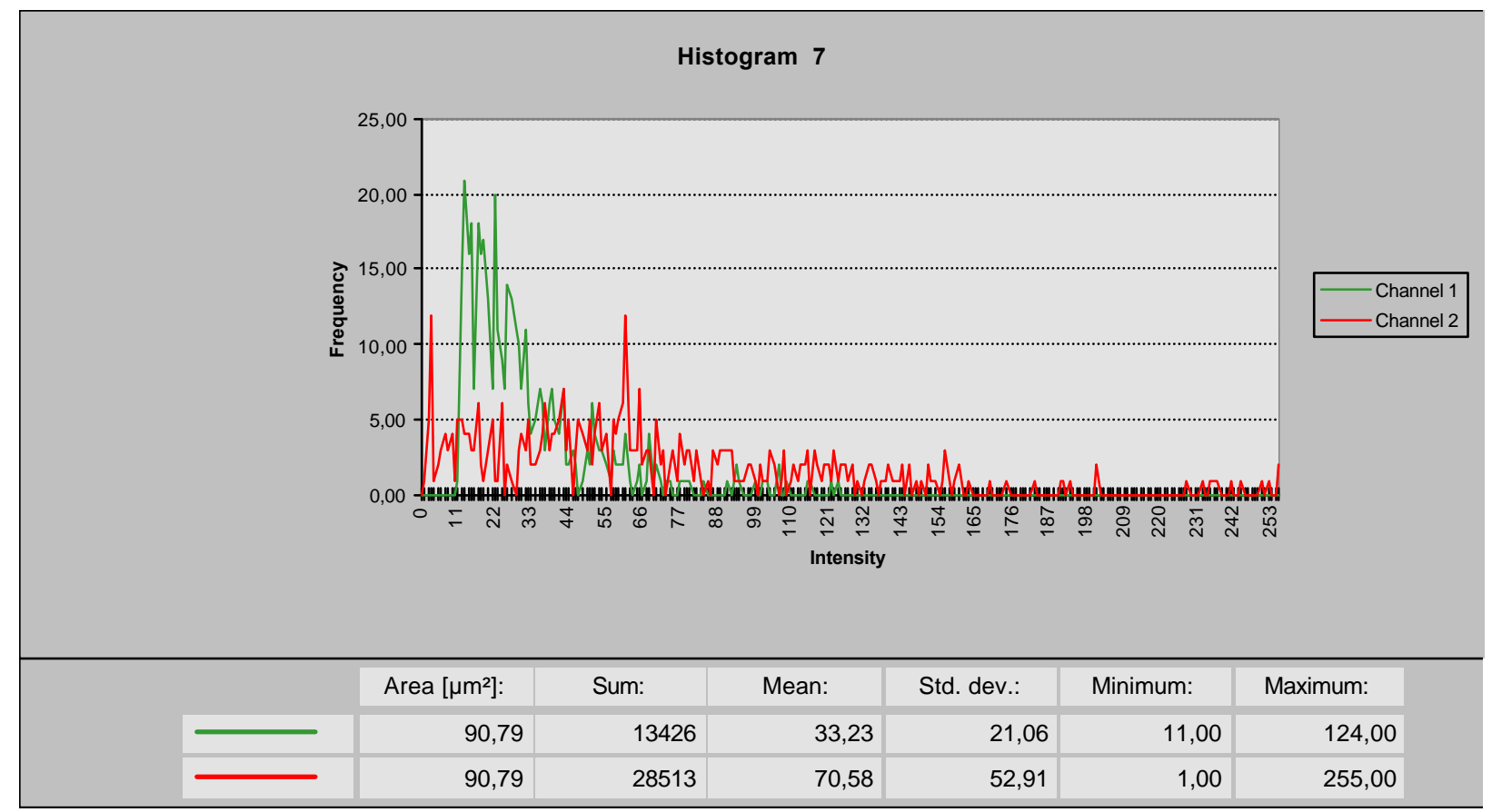

FIGURA 61 - Região cortical 


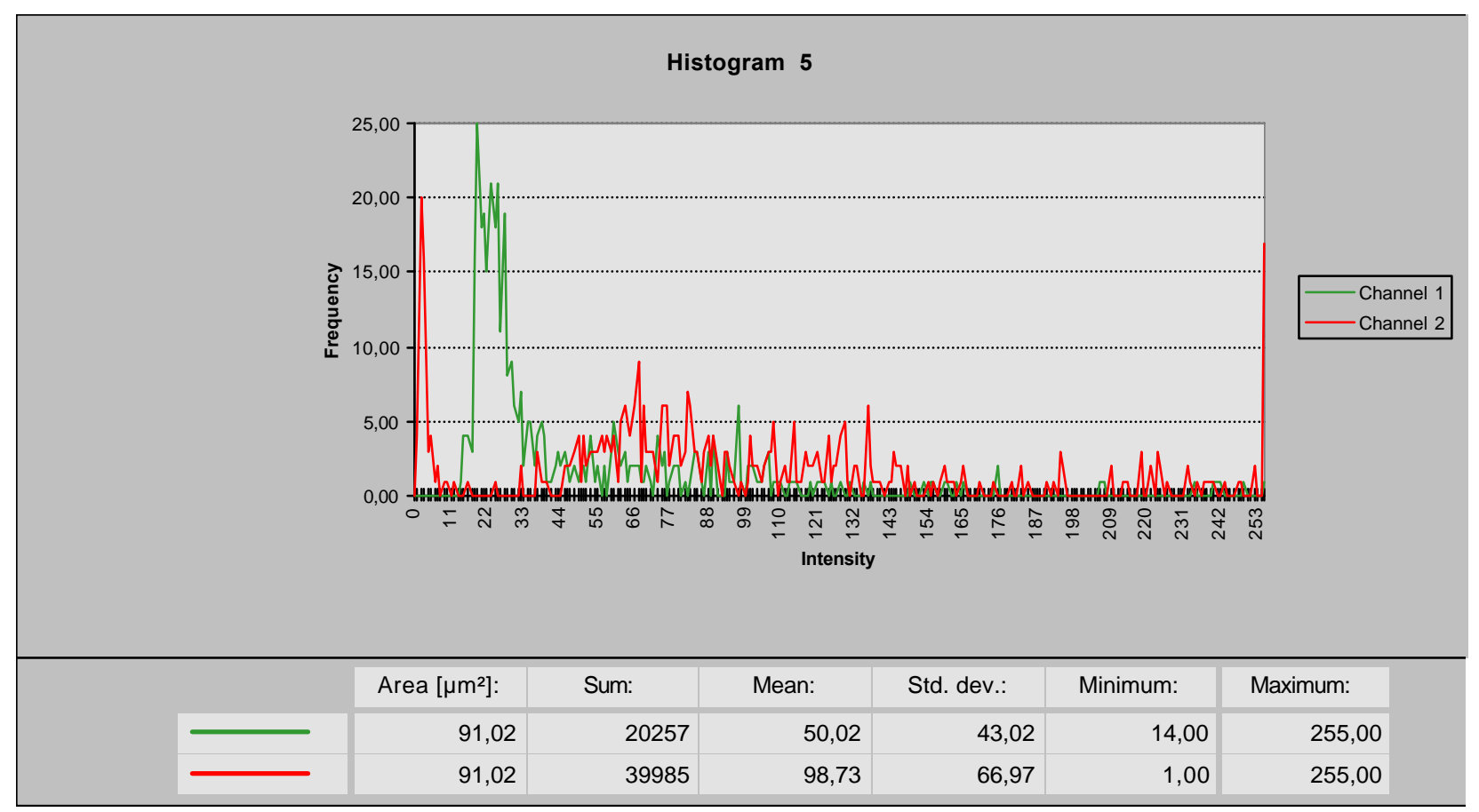

FIGURA 62 - Região sub-cortical

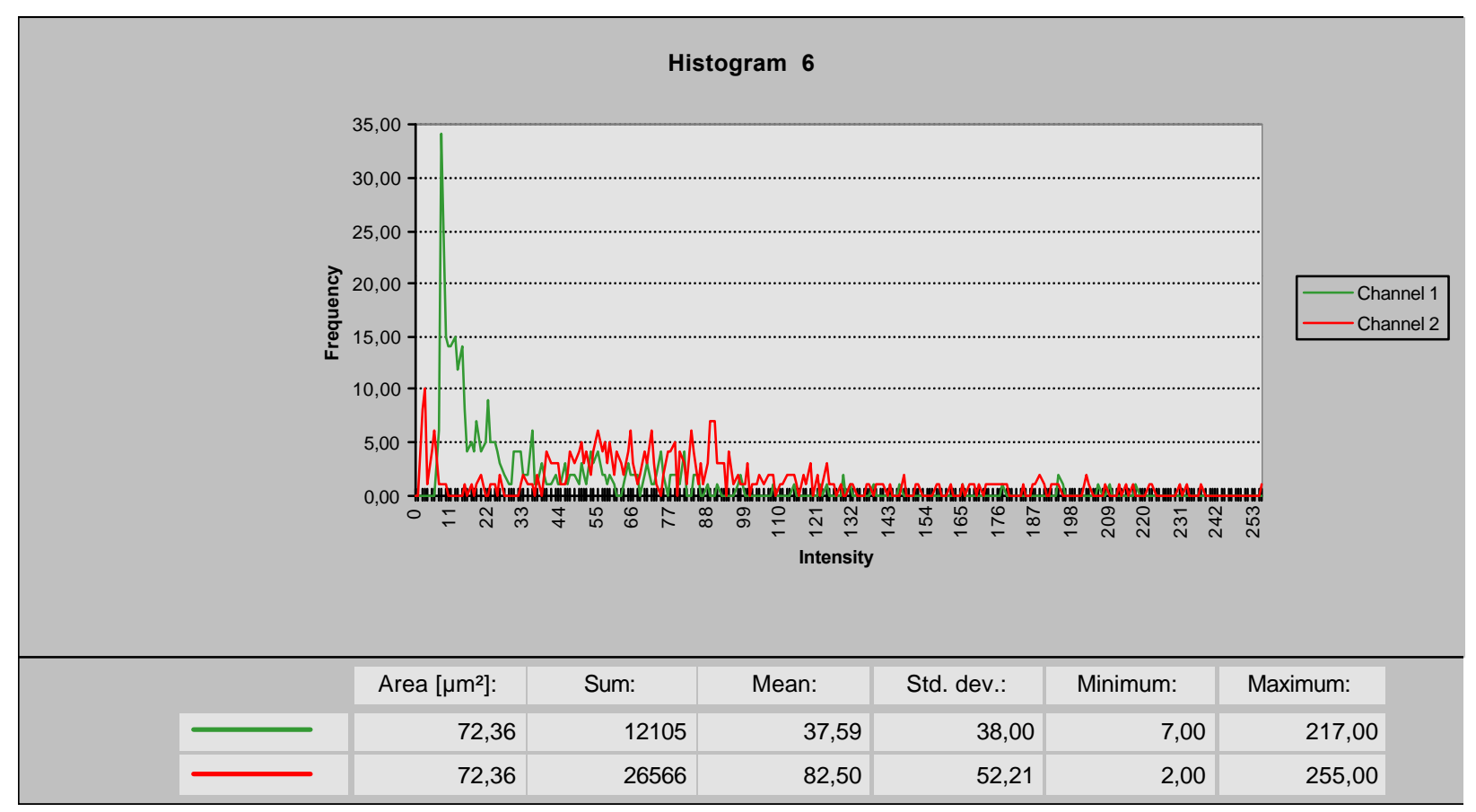

FIGURA 63 - Região medular 


\section{HISTOGRAMA DA LÂMINA 5}

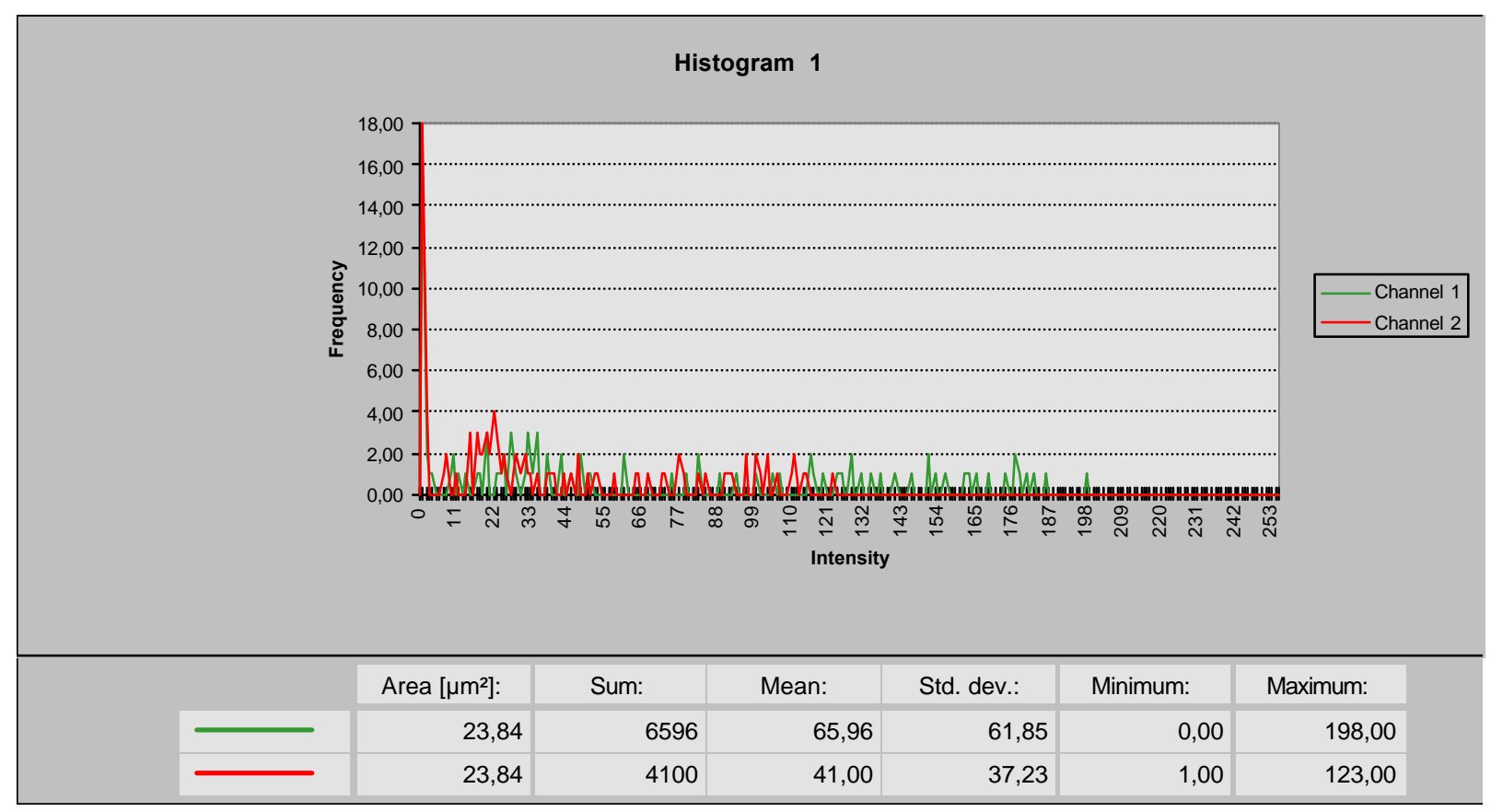

FIGURA 64 - Região cortical

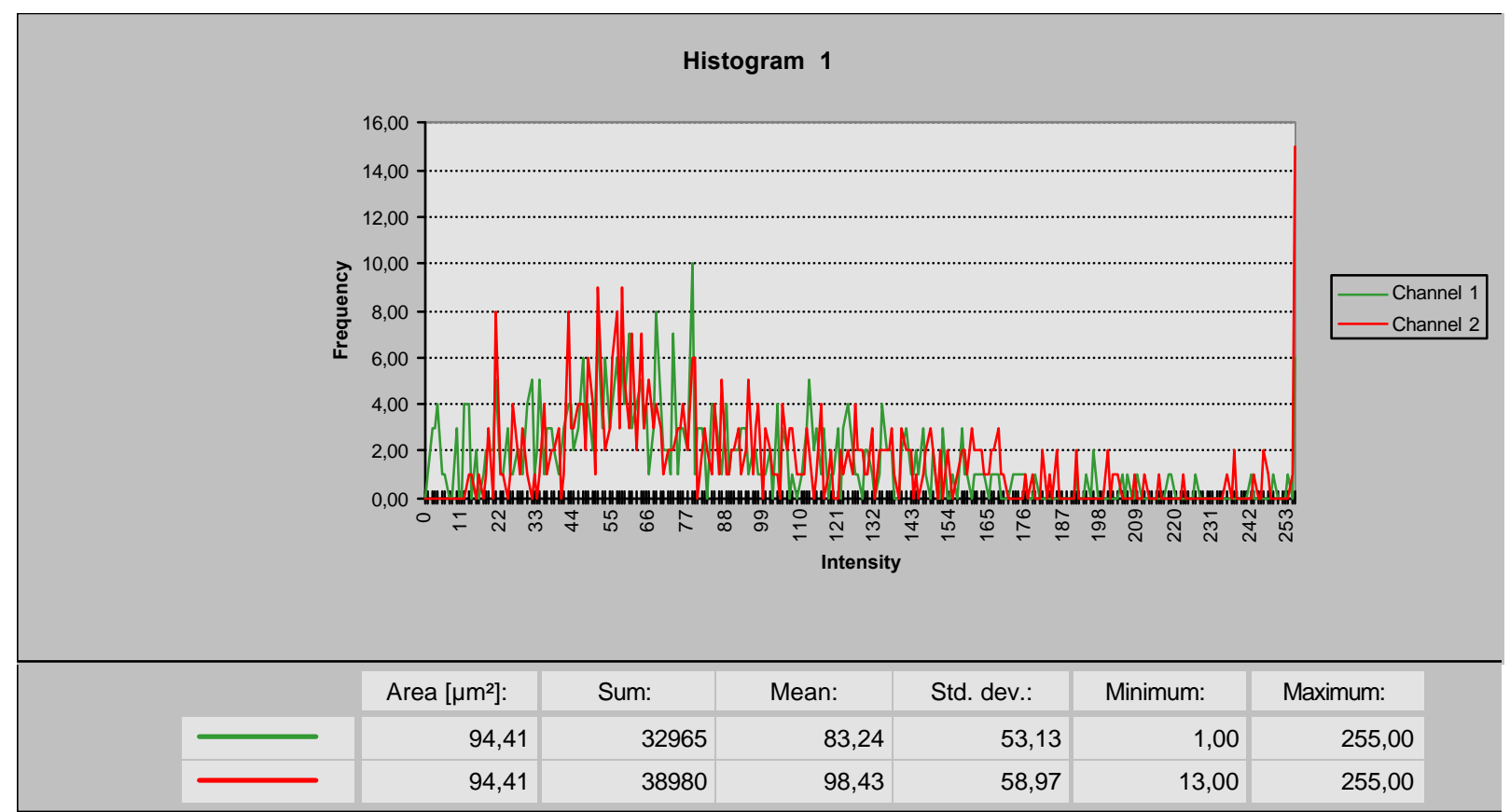

FIGURA 65 - Região sub-cortical 


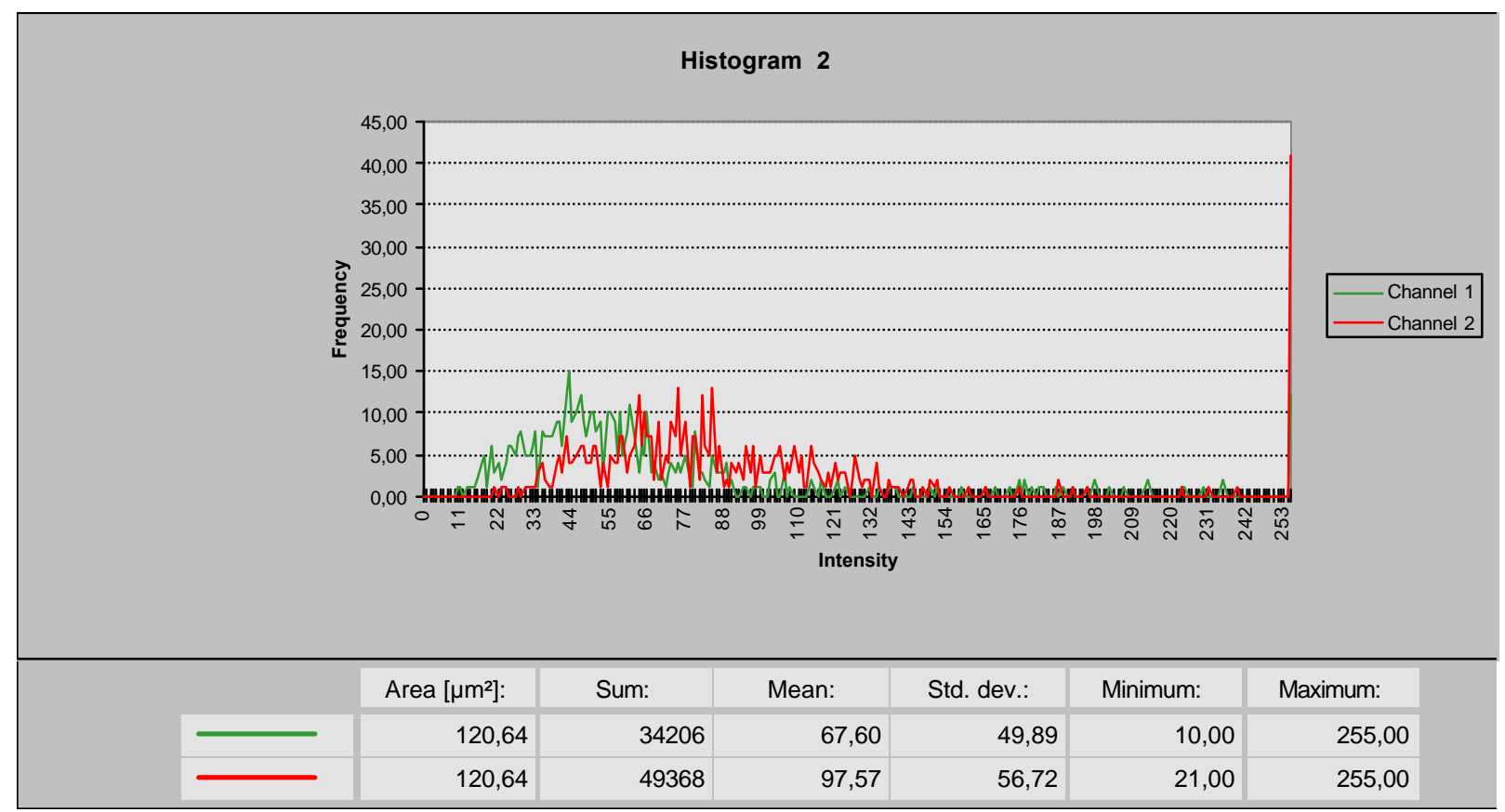

FIGURA 66 - Região medular

\section{HISTOGRAMA DA LÂMINA 6}

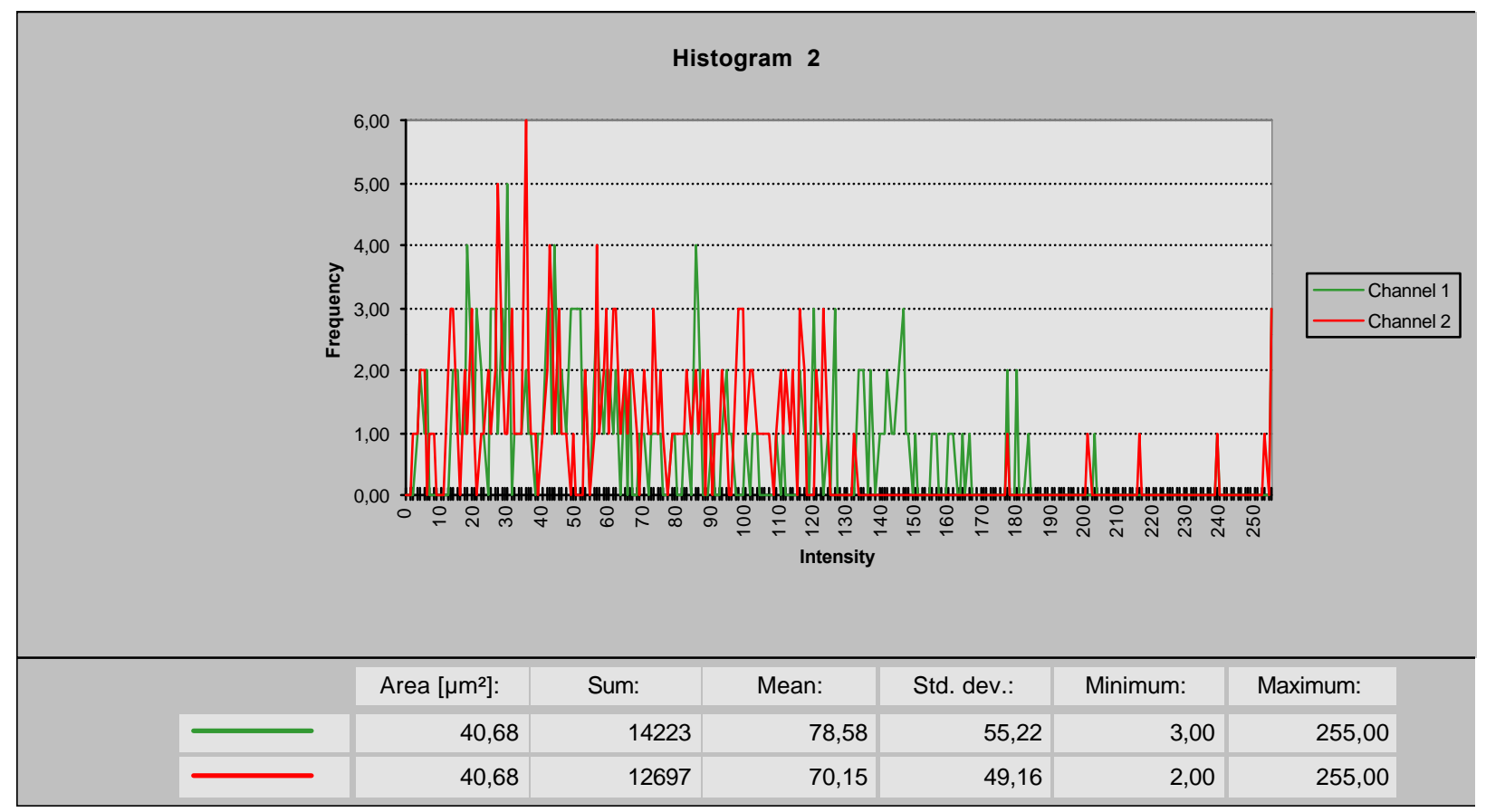

FIGURA 67 - Região cortical 


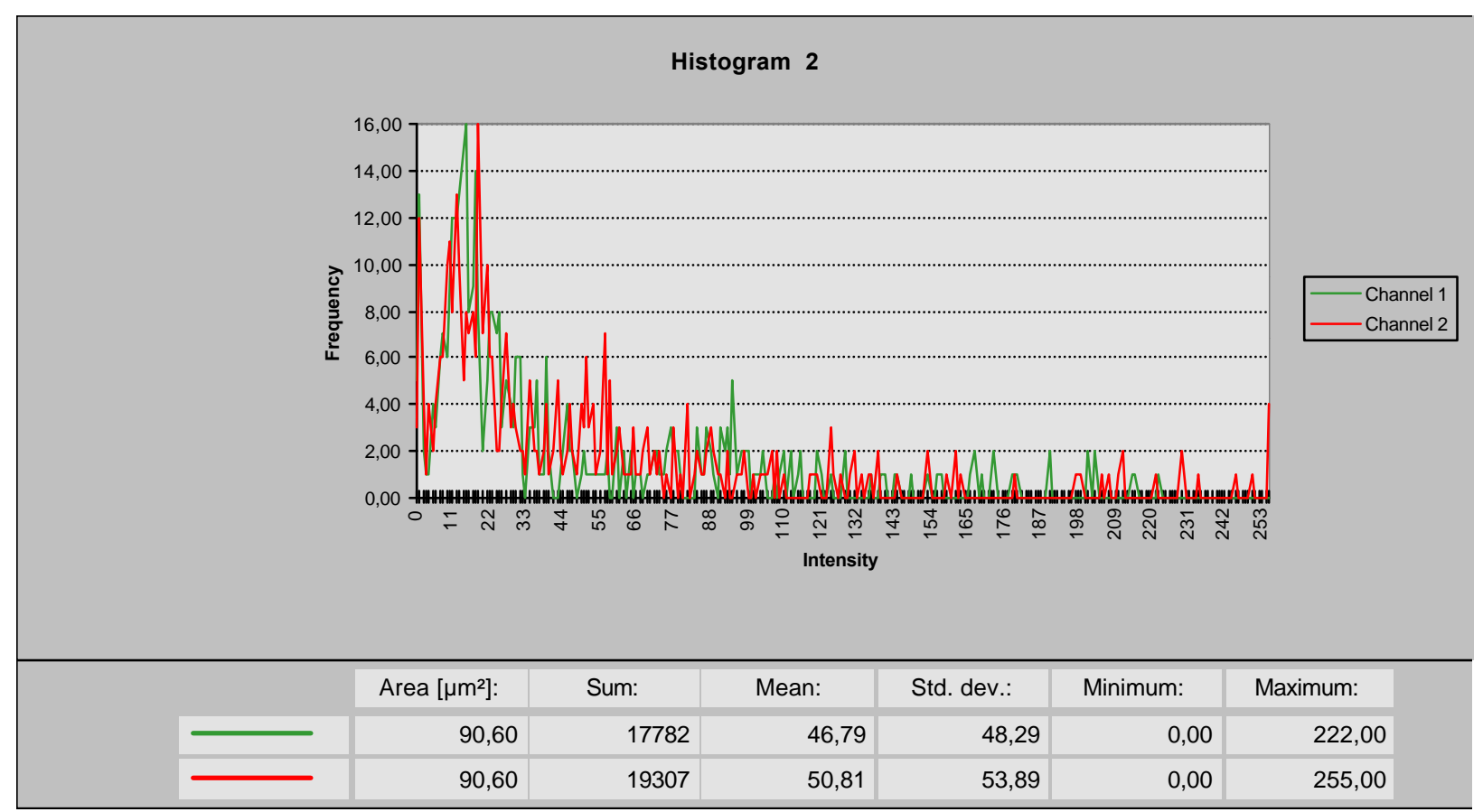

\section{FIGURA 68 - Região sub-cortical}

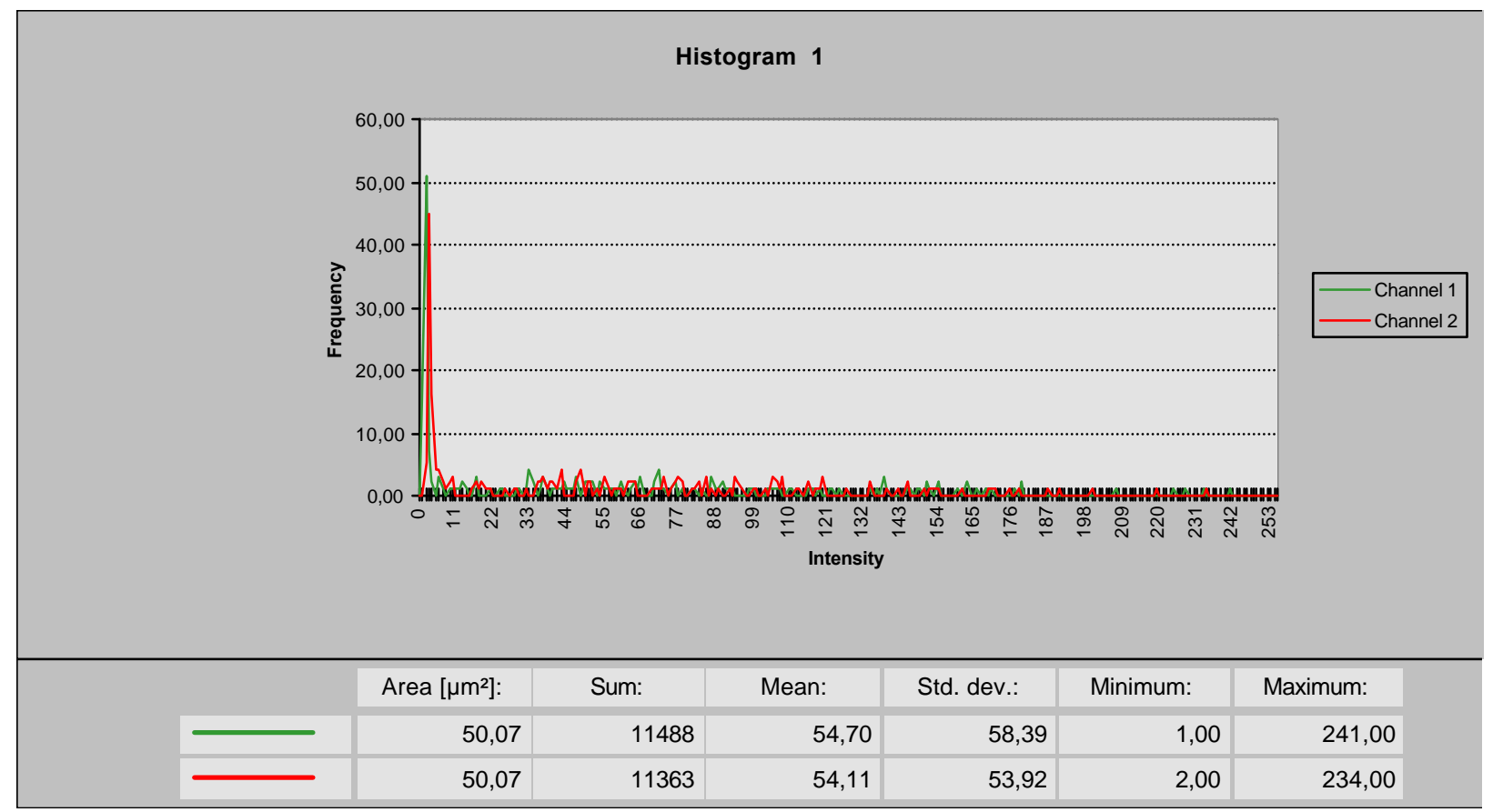

FIGURA 69 - Região medular 
6 - DISCUSSÃO 


\section{6 - DISCUSSÃO}

Os implantes odontológicos apresentaram notáveis avanços nos últimos 20 anos, porém os pesquisadores ainda tentam elucidar e, ao mesmo tempo, aprimorar os sistemas de implantes, buscando uma otimização de suas características.

Os sistemas de implantes mais modernos utilizam-se do titânio comercialmente puro grau I, para confecção dos dispositivos a serem instalados no tecido ósseo. O formato da grande maioria dos implantes atuais é o de parafuso, e a razão para esta escolha baseia-se no fato de apresentarem maior superfície de contato com o tecido ósseo, maior estabilidade inicial favorecendo a cicatrização e uma melhor distribuição de forças na superfície entre 0 implante a 0 tecido ósseo ${ }^{5,6,7,8,9}$.

Os princípios que regem a inserção dos implantes para que se possa assegurar uma alta taxa de sucesso, com a permanência dos mesmos a longo prazo são: a) uso de materiais biocompatíveis em sua confecção; b) formato de parafuso; c) técnica cirúrgica que permita ao osso circunjacente realizar a osseointegração e d) permanência por um período de tempo sem carga funcional sobre o implante. Os processos químicos e biológicos que ocorrem na interface implante/osso dependerão destes fatores para que a osseointegração possa ocorrer 
com sucesso. O uso do titânio puro como material escolhido para a confecção dos implantes modernos permite a ocorrência de um fenômeno cicatricial com ausência de cápsula fibrosa ao redor dos mesmos, conhecido como osseointegração ${ }^{14,15}$.

Atualmente, os trabalhos publicados na área da implantodontia demonstram grande interesse dos pesquisadores em desenvolver o tratamento da superfície dos implantes para que estes possam obter a melhor resposta possível do osso circunjacente tornando a formação óssea cada vez mais intensa na sua periferia ${ }^{18,19,35,62,73,83}$.

Alguma características da superfície do implante tais como composição, topografia, rugosidade e energia são fundamentais e tornase difícil diferenciar os efeitos individuais de cada fator. Inicialmente todos estes fatores influenciarão a cicatrização, determinando quais serão as proteínas adsorvidas sobre a superfície do implante, assim como as células que sofrerão ou não adesão. Desta forma, a energia superficial pode ter um efeito sobre os estágios finais da formação óssea e da calcificação influenciando os tipos de células que inicialmente se aderem sobre o material e diferenciam a interface implante-célula. $O$ efeito combinado do material e da resposta celular inicial determina a resposta orgânica ao material implantado a longo prazo ${ }^{10}$.

Imediatamente após a inserção de um implante, uma camada de componentes orgânicos e inorgânicos oriundos do plasma revestem sua estrutura. A primeira proteína e ligar-se instantaneamente 
ao implante é a fibronectina, cuja seqüência do sítio de união permitirá a adesão de células mesenquimais posteriormente. Algumas outras proteínas sofrerão adesão durante os primeiros eventos cicatriciais como a albumina e a imunoglobulina G. De uma forma geral as proteínas sofrerão adesão durante os primeiros 5 minutos após a inserção do implante, enquanto as células levarão algumas horas para iniciarem o processo de adesão. Após aderirem sobre a superfície do implante, as células passam por processos de proliferação e diferenciação que são influenciadas pela rugosidade superficial ${ }^{76,83}$.

As diversas teorias sobre que tipo de superfície pode promover a melhor osseointegração pelos tecidos circunjacentes podem ser avaliadas adequadamente por meio de estudos in vivo. O trauma cirúrgico necessário para a inserção de um implante deveria cicatrizar de acordo com os mecanismos normais de inflamação e reparo de uma ferida. A presença do implante, entretanto, fornece a oportunidade para que estes mecanismos sejam alterados, permitindo a cicatrização do tecido ósseo justaposto à estrutura do implante, o que é conhecido como osseointegração. A rugosidade superficial altera a capacidade de um implante sofrer osseointegração em maior ou menor intensidade. Os trabalhos mais recentes apresentados na literatura demonstram que a maior rugosidade superficial leva à ocorrência de uma maior osseointegração ao redor dos implantes ${ }^{13,19,73,41,42,75}$. Tal fato pode ser observado quando implantes com várias configurações e diferentes 
rugosidades foram implantadas na tíbia de coelhos. A força de torque de remoção nos implantes com superfícies mais lisas foram significativamente menores quando comparadas com a remoção dos implantes mais rugosos, tanto para as formas cilíndricas quanto para as formas de parafuso. Estas diferenças puderam ser constatadas até mesmo 3 semanas após a inserção dos implantes ${ }^{36,45,46,47}$.

Os valores do torque de remoção obtidos neste estudo apresentam uma alta correlação com os valores obtidos por diversos trabalhos na literatura, o que pode ser observado ao analisarmos, por exemplo, os valores obtidos por JOHANSSON; ALBREKTSSON ${ }^{45}$ em 1987 para o torque de remoção após 3 semanas $(10 \mathrm{Ncm})$ e neste estudo após 15 dias $(7,30 \mathrm{Ncm})$. Após 3 meses os valores foram 68,0 $\mathrm{Ncm}$ na literatura e neste trabalho 52,65 Ncm, sendo que após 180 dias os autores encontraram $77,6 \mathrm{Ncm}$ enquanto este estudo constatou 79,7 Ncm. Podemos observar um comportamento similar entre os implantes do Sistema NAPIO e os implantes do Sistema NobelPharma, no que diz respeito à força necessária para remoção por torque. Torna-se evidente que as diferenças apresentadas entre os valores podem estar relacionadas às diferenças de rugosidade superficial apresentadas pelos dois sistemas, porém estas diferenças não são significativas para os valores apresentados.

A comparação entre o osso da tíbia de um coelho e o osso alveolar humano não pode ser interpretada como um modelo de estudo 
perfeito, porém quando sistemas de implantes semelhantes produzem resultados parecidos podemos extrapolar a interpretação para um resultado positivo. O osso da tíbia de um coelho apresenta estabilização do implante devido à inserção bicortical nos primeiros momentos da fase cicatricial, porém a evolução dos resultados de torque ao longo de tempo indicam que há melhora progressiva das condições ósseas.

O espécime de 180 dias mostra claramente que 0 resultado de acréscimo na resistência ao torque progride bem além da cicatrização inicial. Mesmo em humanos, os resultados clínicos sugerem este mesmo fenômeno, pois a perda de implantes concentra-se em períodos curtos de cicatrização.

Ao analisarmos os cortes histológicos por microscopia confocal de varredura a laser, podemos perceber que desde o momento da inserção até o sacrifício dos animais, os marcadores da atividade óssea (tetraciclina, calceína e alizarina) demonstraram ocorrer um intenso metabolismo do tecido ósseo ao redor do implante de titânio. Este metabolismo apresentou-se cada vez mais intenso levando a uma contínua aposição óssea até o $90^{\circ}$ dia pós-inserção (lâminas 5 e 6). Outro importante fator observado foi a presença constante dos marcadores da atividade óssea nas regiões sub-cortical e medular, o que poderia sugerir que a estabilidade secundária estaria diretamente ligada à capacidade do endósteo para formar tecido ósseo e à capacidade da superfície do implante em estimular esta proliferação celular, 
favorecendo este tipo de cicatrização. Este hipótese já havia sido citada na tese de doutorado de ARAGONES ${ }^{10}$.

Para análise dos resultados objetivos devem ser observadas as figuras referentes aos resultados de perfil de histograma de absorção de laser.

Os resultados mais precoces (figuras 40,41 e 42) indicam valores médios de atividade de incorporação de marcadores semelhantes para as três áreas observadas ( média de absorção de 93,18 e 101,96 para os dois canais na região cortical) , contra 72,41134,67 para a região sub-cortical e 39,02-94,05 para a região medular. Isto indica que, além da maior penetração do feixe vermelho, devido à sequência de aplicação de marcadores, há maior concentração de atividade ósses na região cortical.

Para o espécime número 3 (figuras 43,44 e 45) acentuase o maior valor para a região cortical, porém com predominância do canal verde. Há porém neste espécime, um crescimento de valores médios para a região sub-cortical, com diminuição dos índices para a área medular. Assim, a região sub-cortical mostra valores próximos $(55,84-35,78)$ aos obtidos na região cortical $(64,68-53,17)$.

Esta tendência fica clara na análise do espécime número 4. Os valores demonstrados nas figuras 46,47 e 48 mostram que houve maior atividade óssea na região sub-cortical do que na região cortical, mostrando ainda valores já expressivos na região medular. Há portanto 
uma migração da cicatrização, ou ao menos da incorporação de marcadores de uma área inicialmente cortical para as regiões mais profundas do tecido ósseo.

Para o espécime 5 (Figuras 49,50 e 51) são mais consistentes, comprovando a ocorrência de fenômenos cicatriciais do endósteo para a formação ósse medular. Na região medular há uma incorporação absolutamente linear de marcadores, como prova a análise gráfica.

O espécime 6 (Figuras 52,53 e 54) mostra atividade de remodelamento ósseo, mesmo em períodos mais longos, demonstrando haver picos bem definidos de maior absorção de marcadores. Estes picos indicam a diferenciação existente entre osso novo e osso já formado. Apesar do comprimento das linhas de análise serem bastante variadas, a atividade óssea medular parece persistir durante longo tempo de cicatrização.

Os picos observados na sequência de tempos de administração de marcadores, indicam forte atividade inicial, com grande velocidade de produção óssea, que se mantém relativamente consistente com o tempo, indicando atividade óssea progressivamente incrementada para áreas mais próximas do osso medular.

Os histogramas de intensidade $\mathrm{X}$ frequência por área foram feitos no sentido de eliminar parcialmente $s$ condições dependentes do operador na escolha de linhas de análise de perfis. 
Como atinge uma área mais vasta, os valores de absorção são melhores distribuídos, embora esta análise não permite a visualização de picos de absorção em relação à áreas previamente definidas, ou seja, não é possível avaliar as velocidades de formação óssea.

As figuras do espécime 1 ( Figuras 55,56 e 57) indicam nitidamente picos de absorção menores, contrastando com uma aparência mais retilínea em outras áreas. Esta "turbulência" da absorção indica atividade metabólica para a área cortical maior que em ourtas áreas, onde a distribuição uniforme sugere a presença de ruídos de absorção em todas as frequências.

Já para o espécime 3 (Figuras 58,59 e 60), começam a surgir frequências maiores para absorção de ambos os canais, de maneira mais intensa na região sub-cortical, comprovando os resultados das análises de linhas de perfil. Estes resultados também comprovam que a atividade óssea distribui-se mais profundamente com o tempo.

Para o espécime 4 (Figuras 61,62 e 63) há uma situação de bastante semelhança da distribuição de valores de absorção. As médias indicam predominância, ainda, para a região sub-cortical $(50,02-$ 98,73), mas os valores de medular são agora ligeiramente maiores aos obtidos na região cortical, ao contrário do espécime anterior.

Há diminuição expressiva de atividade ósse cortical no espécime 5 (Figuras 64,65 e 66). A observação simples dos gráficos indica atividades mais intensas nas áreas mais profundas, embora a 
incorporação de marcadores seja, de maneira esperada, menor que nos espécimes de tempos menores de cicatrização. Estas imagens comprovam a hipótese que a área sub-cortical alimenta a migração celular para as regiões mais profundas do osso.

Nas Figuras 67,68 e 69 esta observação pode ser claramente confirmada. Há atividade metabólica expressiva na área subcortical, muito maior que em outras regiões.

Desde conjunto de dados pode-se portanto depreender uma série de fatos, sugeridos em outras observações, aqui comprovadas:

- a atividade metabólica inicial se concentra na região cortical, talvez em razão de seu alto "turn-over" ou em razão ainda de ser a área , æo menos no coelho, mais afetada pelo trauma cirúrgico;

- é absolutamente consistente a formação óssea que se "aprofunda" no tecido ósseo.

- A fonte formadora de tecido ósseo é tipicamente a região sub-cortical, ou mais precisamente, no endósteo. Esta região é estimulada, não pelo trauma cirúrgico, mas devido ao tempo que ocorrem os processos formativos, pela presença de superfície metálica osteocondutora. 
- A superfície metálica não possui efeito osteoindutor, pois a formação de maior atividade óssea medular se dá após o estímulo sub-cortical. O reforço de trabéculas, que implica em maior resistência mecânica á remoção por torque se dá aparentemente por aposição de tecido ósseo vindo da região sub-cortical. O estímulo á formação óssea medular no coelho é bastante diminuto, talvez pela baixa densidade celular desta área.

- Há, portanto, estreita correlação entre os valores obtidos por torque e aqueles visualizados pela incorporação de marcadores excitáveis por argôniokriptônio.

- Os valores de resistência mecânica aumentadas ocorrem devido ao aumento da espessura de tecido ósseo mais denso na região sub-cortical, aumentando assim a faixa de travamento mecânico do implante, embora ocorra atividade proliferativa na região medular.

O tratamento ácido realizado na superfície dos implantes NAPIO pode ser o responsável pela boa resposta do tecido ósseo medular em contato com o implante. Não podemos afirmar com toda 
certeza a existência de uma relação direta entre 0 grau de osseointegração e a força de remoção por torque, porém, para um mesmo animal, verificamos que quanto maior a quantidade de tecido ósseo observada ao redor do implante, maior a força de torque necessária para a remoção do implante de cabeça quadrada associado.

A osseointegração, portanto, não pode ser definida, como em muitos trabalhos, como aumento da área de contato total do tecido ósseo. Isto na verdade não ocorre, à não ser na região sub-cortical. Talvez o melhor conceito de osseointegração seja derivado da capacidade de 1) promover estímulo migratório a partir das células do endósteo) e 2) aumento da resistência mecânica à remoção derivado da maior espessura de cortical e maior grau de mineralização do osso medular.

À luz destas novas observações, o conceito clássico de osseointegração, por análise de percentual de área de contato, deve ser imediamente revisto.

O mérito do alto grau de sucesso dos implantes modernos é creditado a uma série de fatores como o formato do implante (parafuso), o material constituinte, sua energia superficial, sua rugosidade superficial, e a todo o extenso protocolo cirúrgico e cuidados pós-operatórios necessários para que o processo de osseointegração possa ocorrer sem perturbações. O sucesso destes implantes pode ser demonstrado na literatura pela correlação dos resultados entre a 
ocorrência de osseointegração e os resultados clínicos positivos.

Sem dúvida, para melhoria dos resultados clínicos, especialmente em áreas de pouca densidade óssea, a chave para maiores índices de sucesso talvez seja a busca de tratamentos superficias de toda espécie que permitam melhora acentuada nas condições de "espessamento" das corticais. Curiosamente, a tendência de pesquisas e marcas comerciais é preservar a área próxima ao colo dos implantes sem tratamento superficial, ou com pouca rugosidade, 0 que não parece ser o melhor caminho para melhoria das condições de sobrevivência dos implantes. 
7 - CONCLUSÕES 


\section{7 - CONCLUSÕES}

Baseado nos resultados apresentados neste estudo, podemos concluir que:

- a força de remoção por torque apresentou uma relação diretamente proporcional ao intervalo de tempo pós-inserção, ou seja, quanto maior o tempo decorrido após o ato cirúrgico, maior a força de torque necessária para a remoção do implante. Há igualmente forte correlação entre as forças de torque obtidas e os fenômenos da cicatrização óssea.

-houve migração das áreas de atividade óssea, com 0 tempo, das regiões mais superficiais para as áreas mais profundas, demonstrando que a fonte de maior formação óssea é o endósteo subcortical.

- a técnica de microscopia confocal a laser se mostra de grande auxílio no campo da avaliação dos tecidos periimplantares;

- os trabalhos futuros na área da implantodontia possuirão papel fundamental na melhora da superfície dos implantes com a finalidade de potencializar a osseointegração. 
REFERÊNCIAS BIBLIOGRÁFICAS 


\section{REFERÊNCIAS BIBLIOGRÁFICAS ${ }^{*}$}

1 - ADELL, R. et al. A 15-year study of osseointegrated implants in the treatment of the dentulous jaw. Int. J. Oral Surg., v.10, p.387416, 1981.

2 - ADELL, R. et al. Marginal tissue reactions at osseointegrated titanium fixtures. (I) A 3year longitudinal prospective study. Int. J. Oral maxillofac. Surg., v.15, p.39-52, 1986.

3 - ALBREKTSSON, T. et al. Osseointegrated oral implants. A swedish multicenter study of 8.139 consecutively inserted novelpharma implants. J. Periodontol., v.59, n.5, p.287-96, 1988.

4 - ALBREKTSSON, T.; HANSSON, H.A. An ultrastructural characterization of the interface between bone and spputered titanium or stainless steel surfaces. Biomaterials, v.7, p.201-5, May 1986.

5 - ALBREKTSSON, T.; SENNERBY, L. Direct bone anchorage of oral implants: clinical and experimental considerations of the concept of osseointegration. Int. J. Prosthod., v.3, n.1, p.30-41, 1990.

6 - ALBREKTSSON, T.; ZARB, G.A. Current interpretations of the osseointegrated response: clinical significante. Int. J. Prosthod., v.6, n.2, p.25-105, 1993.

"Normas recomendadas para uso no âmbito da Universidade de São Paulo, com base no documento "Referências Bibliográficas: exemplos", emanado do Conselho Supervisor do Sistema Integrado de Bibliotecas da USP, em reunião de de 20 de setembro de 1990. 
7 - ALBREKTSSON, T. Direct bone anchorage of dental impalnts. J. prosth. Dent., v.50, n.2, p.255-61, 1983.

8 - ALBREKTSSON, T. et al. Osseointegrated titatium implants: requirements for ensuring a long-lasting, direct bone-to-implant anchorage in man. Acta Orthodp. Scand., v.52, p.155-70, 1981.

9 - ALBRETSSON, T.; HANSSON, H.A.; IVARSSON, B. Interface analysis of titanium and zirconium bone implants. Biomaterials, v.6, p.37-101, Mar. 1985.

10 - ARAGONES, L.C.A. Análise comparativa do comportamente de implante de $\mathrm{Ti}$ cp com diferentes trtamentos de superfície. An;alise microbiológica e de torque de Iremoção. Tese (doutorado), FOB-USP, Bauru, 1996.

11 - ARLIN,M. Dental implants. Periodontal considerations. J. Canad. Dent. Ass., v.8, p.615-7, 1987.

12 - BINON, P.P.; WEIR, D.J.; MARSHALL, J.J. Surface analysis of an original Bränemark implant and three related clones. Int. J. Oral Maxillofac. Implants, v.7, n.2, p.168-75, 1992.

13 - BOWERS, K.T. et al. Optimization of surface micromorphology for enhanced osteoblast responses in vitro. Int. J. Oral Maxillofac. Implants, v.7, n.3, p.203-10, 1992.

14 - BRÄNEMARK, P.I. et al. An experimental and clinical study of osseointegrated implants penetrating the nasal cavity and maxillary sinus. J. Oral Maxillofac. Surg., v.42, p.497-505, 1984.

15 - BRÄNEMARK, P.I. Osseoingration and its experimental background. J. prosth. Dent., v.50, n.3, p.399-410, 1983. 
16 - BROSH, T.; PERSOVSKI, Z; BINDERMAN, I. Mechanical properties of bone-implant interface: an in vivo comparison of the parameters at placement and at 3 months. Int. J. Oral Maxillofac. Implants, v.10, p.729-35, 1995.

17 - BRUNETTE, D.M. The effects of implant surface topography on the behavior of cells. Int. J. Oral Maxillofac. Implants, v.3, n.4, p.231-46, 1988.

18 - BUDD, T.W. et al. Visualization and initial characterization of the titanium boundacy of the bone-implant interface of osseointegrated implants. Int. J. Oral Maxillofac. Implants, v.7, p.151-60, 1992.

19 - BUSER, D. et al. Influence of surface characteristics on bone integration of titanium implants. A histomorphometric study in miniature pigs. J. Biomed. Mater. Res., v.25, p.889-902, 1991.

20 - BUSER, D. et al. Titanium implants with a true periodontal ligament: an alternative to osseointegrated implants? Int. J. Oral Maxillofac. Implants, v.5, n.2, p.123-6, 1990.

21 - CARLSSON, L. et al. Osseointegration of titanium implants. Acta Orthop. Scand., v.57, p.285-9, 1986.

22 - CARLSSON, L. et al. Removal torques for polished abd rough titanium implants. Int. J. Oral Maxillofac. Implants, v.3, n.1, p.214, 1988.

23 - CARLSSON, L.V.; ALBREKTSSON, T.; BERMAN, C. Bone response to plasma-cleaned titanium implants. Int. J. Oral Maxillofac. Implants, v.4, n.3, p.199-204, 1989. 
24 - CARR, A.B. et al. Reverse torque failure of screw-shaped implants in baboons: baseline data for abutment torque application. In. J. Oral Maxillofac. Implants, v.10, p.167-74, 1995.

25 - CLOKIE, C.M.L.; WARSHAWSKY, H. Morphologic and radioautographic studies of bone formation in relation to titanium implants using the rat tibia as a model. Int. J. Oral Maxillofac. Implants, v.10, -.155-65, 1995.

26 - COX, J.F.; ZARB, G.A. The longitudinal clinical efficacy of osseointegrated dental implants: a 3-year report. Int. J. Oral Maxillofac. Implants, n.2, p.91-100, 1987.

27 - DAVIES, J.E.; LOWENBERG, B.; SHIGA, A. The bone-titanium interface "in vitro". J. Biomed. Mater. Res., v.24, n.10, p.1289306, Oct. 1990.

28 -Den BRAGGER, E.T. et al. Scanning electron microscopic, transmission electron microscopic, and confocal laser scanning microscopic observation of fibroblasts cultured on microgrooved surfaces of bulk titanium substrata. J. Biomed. Mater. Res., v.40, p.425-33, 1998.

29 - DEPORTER, D.A. et al. A histological assessment of the initial healing response adjacent to porous-surfaced, titanium alloy dental implants in dogs. J. Dent. Res., v.65, p.1064-70, 1986.

30 - DEPORTER, D.A. et al. A histological comparison in the dog ofporous-coated or threaded dental implants. J. dent. Res., v.69, n.5, p.1.138-45, 1990.

31 - DONOHUE, W.B.; MASCRÈS, C. Effect of hydroxyapatite on bone formation around exposed heads of titanium implants in rabbits. J. 
Oral Maxillofac. Surg., v.48, n.11, p.1.196-200, 1990.

32 - DOUNDOULAKIS, J.H. Surface analysis of titanium after sterilization: role in implant-tissue interface and bioadhesion. $\mathbf{J}$. prosth. Dent., v.8, n.4, p.471-8, 1987.

33 - ERICSSON, I. et al. A clinical evalaution of fixed-bridge restorations supported by the combination of teeth and osseointegrated titanium implants. J. Clin. Periodont., v.13, p.307-12, 1986.

34 - ERIKSSON, A.R.; ALBREKTSSON, T. Temperature threshold levels for heat-induced bone tissue injury: a vital microscopic study in the rabbit. J. prosth. Dent., v.50, n.1, July 1983.

35 - ETTINGER, R.L. et al. Measurement of the interface between bone and immediate endosseous implants: a piloty study in dogs. Int. J. Oral Maxillofac. Implants, v.8, n.4, p.420-7, 1993.

36 - GOHEEN, K.L. et al. Torque generated by handheld screw-drivers and mechanical torquing devices of osseointegrated implants. Int. J. Oral Maxillofac. Implants, v.9, p.149-55, 1995.

37 - GOTTLANDER, M.; ALBREKTSSON, T.; CARLSSON, L.V. A histomorphometric study of unthreated hydroxtapatite-coated and titanium-coated implants in rabit bone. Int. J. Oral Maxillofac. Implants, v.7, n.5, p.485-90, 1992.

38 - HAIDER, R.; WATZEK, G.; PLENT JUNIOR, H. Effects of drill coaling and bone struction on IM2 implant fixation. J. Oral Maxillafac. Implants, v.8, n.1, p.83-91, 1993.

39 - HANSSON, H.A.; ALBREKTSSON, T.; BRÄNEMARK, P.I. Structural aspects of the interface between tissue and titanium implants. J. prosth. Dent., v.50, n.1, p.108-13, 1983. 
40 - HANTHAMRONGWIT, M. et al. Confocal laser-scanning microscopy for determining the structure of and ketatinocyte infiltration through collagen sponges. J. Biomed. Mat. Res., v.30, p.331-9, 1996.

41 - HELSINGEN, A.E.; LYBERG, T. Comparative surface analysis and clinical performance studies of Bränemark implants and realted clones. Int. J. Oral Maxillofac. Implants, v.9, n.4, p.422-30, 1994.

42 - HENRY, P.J. Comparative surface analysis of two osseointegrated implant systems. Int. J. Oral Maxillofac. Implants, v.2, p.23-7, 1987.

43 - IVANOFF, C.J.; SENNERBY, L.; LEKHOLM, U. Influence of mono and bicortical anchorage on the integration of titanium implants. Int. J. Oral Maxillofac. Surg., v.25, p.229-35, 1996.

44 - IYAMA, S. et al. A study of the regional distribution of bone formed around hydroxyapatite implants in the tibiae of streptozotocininduced diabetic rats using multiple fluorescent labeling and confocal laser scanning microscopy. J. Periodontol., v.68, n.12, p.1169-75, 1997.

45 - JOHANSSON, C.; ALBREKTSSON, T. Integration of screw implants in the rabbit. A one-year follow-up of renmoval torque of titanium implants. Int. J. Oral Maxillofac. Implants, v.2, n.2, p.69-73, 1987.

46 - JOHANSSON, C.; JACOBSSON, M.; ALBREKTSSON, T. Removal force for osseointegrated titanium implants. Advanc. Biomat., v.8, p.87-92, 1988. 
47 - JOHANSSON, C.B.; SENNERBY, L.; ALBREKTSSON, T. A removal torque and histomorphometric study of bone tissue reactions to commercially pure titanium and vitallium implants. Int. J. Oral Maxillofac. Implants, v.6, n.4, p.437-41, 1991.

48 - KASEMO, B.; LAUSMAA, J. Biomaterial and implant surfaces: a surface science approach. Int. J. Oral Maxillofac. Implants, v.3, n.4, p.247-59, 1988.

49 - KAVANAGH, P. et al. A rodent model for the investigation of dental implants. J. prosth. Dent., v.54, n.2, p.252-7, 1985.

50 - KELLER, J.C. et al. Characterization of sterilized $\mathrm{cp}$ titanium implant surfaces. Int. J. Oral Maxillofac. Implants, v.5, n.4, p.360-7, 1990.

51 - KELLER, J.C.; GROTENDORST, G.R.; DOUGHERTY, W.J. Cell attachment to sterilized c.p. Tisurfaces. J. Dent. Res., v.68, n.758, p.276, 1989. (Abstract n.757).

52 - KELLER, J.C.; YOUNG, F.A.; HANSEL, B. Systemic effects of porous Ti dental implants. Dent. Mater., v.1, p.41-2, 1985.

53 - KELLER, J.C.; YOUNG, F.A.; TRANCICK, T.M. A simplified model for studying bone ingrowth. Int. J. Periodont. Rest. Dent., v.2, n.3, p.149-52, 1987.

54 - KLAUBER, C.; LENZ, L.J.; HENRY, P.J. Oxide thickness and surface contamination of six endosseous dental implants a preliminary report. Int. J. Oral Maxillofac. Implants, v.5, n.3, p.264-71, 1990. 
55 - KONIJN, G.A. et al. 40 Confocal microscopy for visualisation of bone remodelling. Path. Res. Pract., v.192, p.566-72, 1996.

56 - LARHEIM, T.A. et al. Comparison of bone resorption at one step and two-step mandibular endosseous implants in dogs. Scand. J. Dent. Res., v.92, p.94-7, 1984.

57 - LAUSMAA, J.; KASEMO, B.; MATTSON, H. Surface spectroscopie characterization of titanium implant materials. Appl. Surface Science, v.44, p.133-46, 1990.

58 - LINDER, L. et al. Electron microscopic analysis of the bone titanium interface. Acta Orthop. Scand., v.54, p.45-52, 1983.

59 - LINDER, L. High-resolution microscopy of the implant-tissue interface. Acta Orthop. Scand., v.56, p.269-72, 1985.

60 - LINDQUIST, L.W. et al. Bone resorption around fixtures in edentulous patients treated with madibular fixed tissue-integrated prosthesis. J. prosth. Dent., v.59, n.1, p.59-63, 1988.

61 - LÜTHY, H.; STRUB, J.R.; SCHÄRER, P. Analysis of plasma flamesprayed coatings on endosseous oral titanium implants exfoliated in man: preliminary results. Int. J. Oral Maxillofac. Implants., v.2, p.197-202, 1987.

62 - MACHBEEM $\mathrm{C}, \mathrm{H}$, et al. Identification of oxide layers of commercially pure titanium in response to cleaning procedures. Int. J. Oral Maxillofac. Implants, v.8, n.5, p.529-83, 1993.

63 - MEFFERT, R.M.; BLOCK, M.S.; KENT, J.N. What is osseointegration? Int. J. Periodont. Rest. Dent., v.4, p.9-21, 1987. 
64 -MICHAELS In vitro connective tissue cell atachment to $\mathrm{cp} \mathrm{Ti.} \mathrm{J.}$ Dent. Res., v.68, p.276, 1989. (Abstract n.759).

65 - PARR, G.R.; STEFLIK, D.E.; SISK, A.L. Histomorphometric and histologic observations of bone healing grond immediate implants in dogs. Int. J. Oral Maxillofac. Implants, v.8, n.5, p.534-40, 1993.

66 - PARR, G.R.et al. Clinical and histological observations of failed twostage titanium alloy basked implants. Int. J. Oral Maxillofac. Implants, v.3, n.1, p.49-56, 1988.

67 - PILLIAR, R.M. et al. Dental implant design-effect on bone remodelling. J. Biomed. Mater. Res., v.25, n.4, p. ..., 1991.

68 - PILLIAR, R.M. Dental implants: materials and design. J. Canad. Dent. Ass., v.56, n.9, p.837-61, 1990.

69 - RAHAL, M.D.; BRÄNEMARK, P.I.; OSMOND, D.G. Response of bone marrow to titanium implants: osseointegration and the establishment of a bone marrow-titanium interface in mice. Int. J. Oral Maxillofac. Implants, v.8, n.5, p.573-79, 1993.

70 - RIEGER, M. R.et al. Finite element analysis of bone-adapted and bone-bonded endosseous implants. J. prosth. Dent.,v.62, n.4, p.436-40, 1989.

71 - ROBERTS, E. Bone tissue interface. J. Dent. Educ., v.52, n.12, p.804-9, 1988.

72 - ROBERTS, W.E. et al. Osseous adaptation to continuous loading of rigid endosseous implants. Amer. J. Orthod., v.86, n.2, p.95-111, Aug. 1984. 
73 - SATOMI, K. et al. Bone-implant interface structures after nontapping and tapping insection of screw-type titanium alloy endosseous implants. J. prosth.Dent., v.39, n.3, p.339-42, 1988.

74 - SENNERBY, L.; THOUSEN, P., ERICSSON, L.E. A morphometric and biomechanic comparation of titanium implants inserted in rabbit cortical and cancellous bone. Int. J. Oral Maxillofac. Implants, v.7, n.1, p.62-71, 1992.

75 - STEFLIK, D.E. et al. Electron microscopy of bone response to titanium cylindrical screw-type endosseous dental implants. Int. J. Oral Maxillofac. Implants, v.7, p.497-507, 1992.

76 - STEFLIK, D.E. et al. Histomorphometry of the dental implant-bone interface: one-year results of a comparative investigation in dogs. Int. J. Oral Maxillofac. Implants, v.9, n.5, p.501-12, 1994.

77 - STEFLIK, D.E. et al. Osteoblast activity at the dental implant-bone interface: transmission electron microscopic and high voltage electron microscopic observations. J. Periodont., v.65, n.5, p.404-13, 1994.

78 - STEINBERG, A.D.; WILLEY, R.; DRUMMOND, J.L. In vivo comparisons of clot formation on titanium and hydroxyapatitecoated titanium. J. Periodont., v.63, n.12, p.990-4, 1992.

79 - TAKESHITA, F. et al. Study of bone formation around dense hydroxyapatite implants using light microscopy, image processing and confocal laser scanning microscopy. Biomaterials, v.18, n.4, p.317-22, 1997.

80 - THOUSEN, P.; ERICSON, L.E. Titanium implants in rabbit knee joints. Acta Orthodp. Scand., v.58, p.265-9, 1987. 
81 - TJELLSTRÖM, A.; JACOBSSON, M.; ALBREKTSSON, T. Removal torque of osseointegrated craniofacial implants: a clinical study. Int. J. Oral Maxillofac. Implants, v.3, p.287-9, 1988.

82 - UEDA, M. et al. The relationship between insertion-torque and removal torque analysed in fresh temporal bone. Int. J. Oral Maxillofac. Implants, v.6, p.442-7, 1991.

83 - WEINLAENDER, M. et al. Histomorphometry of bone apposition around three types of endosseous dental implants. Int. J. Oral Maxillofac. Implants, v.7, n.4, p.491-6, 1992.

84 - WIE, H. et al. Implant-tissue interface of endosseous dental implants in dogs. Validity of clinical evaluation methods. J. prosth. Dent., v.52, n.1, p.76-81, 1984. 


\section{ABSTRACT}




\section{ABSTRACT}

Trying to understand osseointegration, many researches look for better means to evaluate this healing process. In order to analysis this healing process around NAPIO implants is rabbits tibia, a double follow-up was done (torque removal forces and histology).

Seven animals were used in this study and each one received 2 implants (one for confocal scanning laser microscopy analysis and the other to obtain the removal torque). The animals received 3 bone labelers injections of Tetracicline, Alizarine and Calceine on different intervals.

Day 0 - 14 implants on 7 animals

Day 7 - Tetracicline on 6 animals (1, 2, 3, 4, 5 and 6)

Day 15 - Sacrifice animals 1 and 2, and Alizarine animais 3, 4, 5 and 6

Day 21 - Alizarine on animals 3, 4, 5 and 6

Day 45 - Sacrifice animals 3 and 4; Calceine animals 5 and 6

Day 52 - Calceine on animais 5 and 6

Day 90 - Sacrifice animals 5 and 6

Day 180 - Sacrifice animals 7 (no bone labeler) 
At the sacrifice moment the torque removal implants were registered:

Animal $1-7,49 \mathrm{Ncm}$

Animal $2-7,12 \mathrm{Ncm} \quad \Rightarrow$ Mean $=7,30 \mathrm{Ncm}$

Animal $3-35,4 \mathrm{Ncm}$

Animal $4-31,1 \mathrm{Ncm}$

$\Rightarrow$ Mean $=35,25 \mathrm{Ncm}$

Animal $5-58,1 \mathrm{Ncm}$

Animal $6-47,2 \mathrm{Ncm}$

$\Rightarrow$ Mean $=52,65 \mathrm{Ncm}$

Animal $7-79,7 \mathrm{Ncm}$

The remaining implants undergone histologic preparation by Donath technique and were submetted to confocal scanning laser microscopy. This analysis demonstrated a great bone activity on bone/implant interface.

The results showed a continuous bone formation around implants and na increasing torque removal force at different time intervals. 